\title{
Geology and Geochemistry
}

of Uranium

in Marine Black Shales

A Review

GEOLOGICAL SURVEY PROFESSIONAL PAPER 356-C

Prepared on behalf of the

U.S. Atomic Energy Commission

and published with the permission

of the Commission

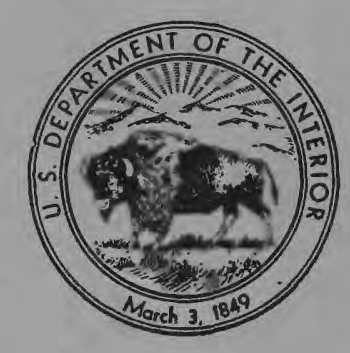




\section{Geology and Geochemistry}

of Uranium

in Marine Black Shales

A Review

By VERNON E. SWANSON

URA N I UM IN CARBONACEOUS ROCKS

GEOLOGICAL SURVEY PROFESSIONAL PAPER 356-C

Prepared on behalf of the

U.S. Atomic Energy Commission

and published with the permission

of the Commission

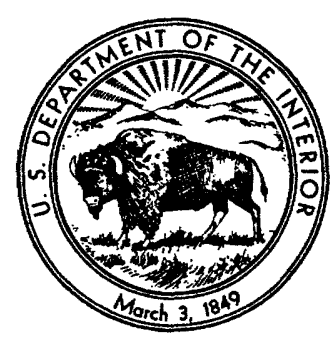

UNITED STATES GOVERNMENT PRINTING OFFICE, WASHINGTON : 1961 


\section{UNITED STATES DEPARTMENT OF THE INTERIOR \\ STEWART L. UDALL, Secretary \\ GEOLOGICAL SURVEY \\ Thomas B. Nolan, Director}

For sale by the Superintendent of Documents, U.S. Government Printing Office

Washington 25, D.C. 


\section{CONTENTS}

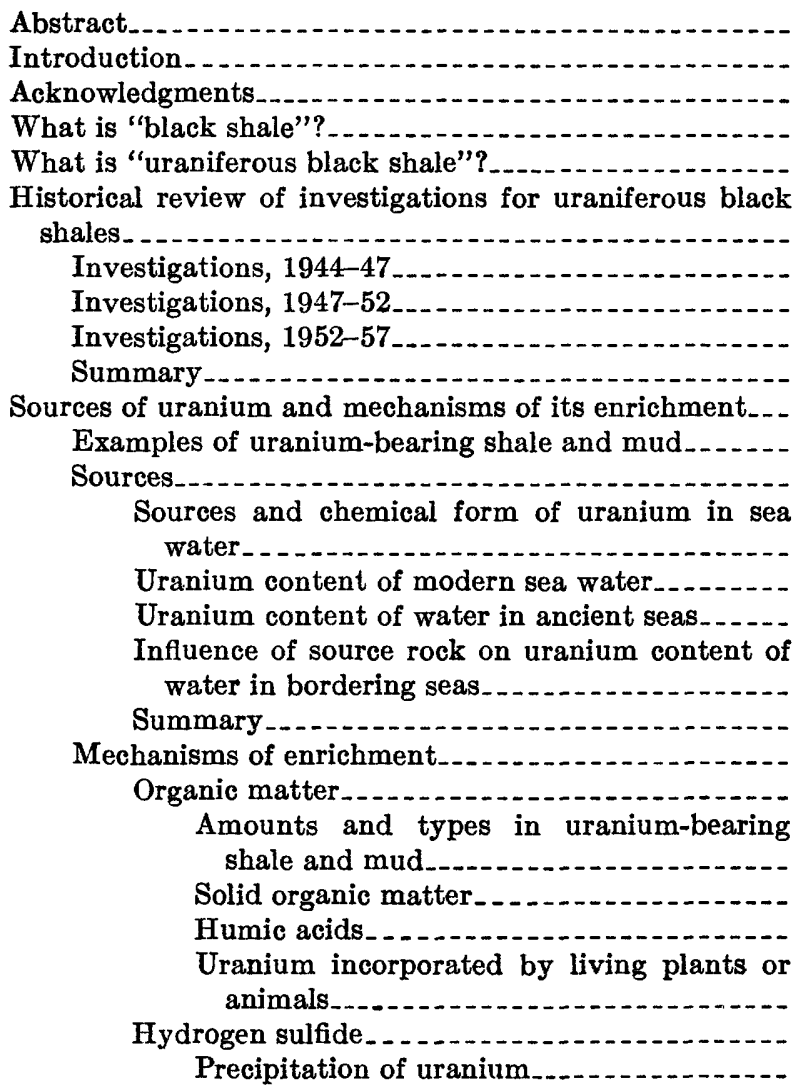

\begin{tabular}{|c|c|c|}
\hline Page & & Page \\
\hline 67 & Sources of uranium-Continued & \\
\hline 68 & Mechanisms of enrichment-Continued & \\
\hline 69 & Hydrogen sulfide-Continued & \\
\hline 69 & Uranium precipitated by hydrogen sulfide in & \\
\hline 70 & Chattanooga shale...... & 90 \\
\hline & Relation of pyrite to uranium & 91 \\
\hline 70 & Bottom water of Norwegian fjords and & \\
\hline 70 & Baltic sea & 92 \\
\hline 71 & Possible extrapolations and interpretations_ & 93 \\
\hline 72 & Phosphate & 95 \\
\hline 73 & Relation to uranium & 95 \\
\hline 74 & Geochemical conditions for deposition..... & 96 \\
\hline 75 & Cycle of deposition & 97 \\
\hline 80 & Other chemical variables. & 98 \\
\hline & Acidity & 98 \\
\hline 81 & Oxidation-reduction potential & 99 \\
\hline 81 & Salinity-1-20 & 99 \\
\hline 82 & Diagenetic changes in black muds & 100 \\
\hline 83 & $\begin{array}{l}\text { Summary } \\
\text { Factors controlling uranium distribution in black }\end{array}$ & 101 \\
\hline 85 & shale & 101 \\
\hline 86 & Known and theoretical relations & 102 \\
\hline 86 & Source of uranium & 102 \\
\hline & Organic matter & 103 \\
\hline $\begin{array}{l}86 \\
87\end{array}$ & Hydrogen sulfide. & 103 \\
\hline 87 & Phosphate. & 104 \\
\hline & $\mathrm{pH}, \mathrm{Eh}$, and salinity & 104 \\
\hline 89 & Conclusion & 104 \\
\hline 90 & rature cited. & 105 \\
\hline 90 & Index & 111 \\
\hline
\end{tabular}

\section{ILLUSTRATIONS}

FIGURe 23. Cross section showing hypothetical distribution of uranium derived from eroded granite and deposited in geosynclinal and platform sediments......

24. Map indicating amounts of dissolved organic matter entering the Baltic Sea area .

25. Cross section of fjord water charged with hydrogen sulfide, with calculations on precipitated uranium........

26. Columnar section of upper part of Chattanooga shale showing distribution of uranium and phosphate.........

27. Graph showing estimated distribution of uranium in shales and muds.

\section{TABLES}

Table 1. Summary of chemical information bearing on concentrations of uranium in marine black shales and muds.......-

2. Laboratory experiments in precipitating and in concentrating uranium

3. Chemical data on bottom sediment and water in Norwegian fjords and in the Baltic Sea near Gotland. 


\title{
URANIUM IN CARBONACEOUS ROCKS
}

\section{GEOLOGY AND GEOCHEMISTRY OF URANIUM IN MARINE BLACK SHALES, A REVIEW}

\author{
By Vernon E. Swanson
}

\begin{abstract}
More than 200 formations in the United States containing marine black shale units, ranging from Precambrian to Tertiary in age, were examined during the period 1944-1957 for black shale that might be exploited as a source of uranium. Black shale beds were checked for their radioactivity at thousands of outcrops, in thousands of feet of well core, in thousands of samples of drill cuttings, and on many hundreds of gamma-ray logs, and an estimated 8,000 samples were chemically analyzed for uranium. Of all the shale beds tested, none was found that could be mined and processed economically for uranium. The Chattanooga shale of the southeastern United States and the phosphatic black shales of Pennsylvanian age in Kansas and Oklahoma were found to be the most extensive uraniferous shales in the United States. Their uranium content is relatively high, generally between 0.005 and 0.010 percent.
\end{abstract}

The exact chemical and physical forms and associations of most of the uranium in marine black shales cannot be determined by existing chemical, microscopic, or other methods. Thus the form, the associations with other shale constituents, and the mechanisms of emplacement of the uranium have to be interpreted from interrelations of other constituents in the sediment, from chemical processes active in the environment of black mud deposition, and from the properties of uranium and the processes resulting in its concentration.

The geologic controls and geochemical processes involved in the concentration of uranium in marine black shales as presented here are based on (a) geologic studies of uraniferous marine black shales, as represented by the upper part of the Chattanooga shale, which contains about 0.008 percent uranium; (b) sedimentologic studies of modern uranium-bearing black muds of the Norwegian fjords and of the Baltic Sea, which contain maxima of 0.006 and 0.001 percent uranium, respectively; (c) hydrologic studies of the waters in which these muds are deposited; and (d) laboratory experiments in uranium precipitation related to conditions observed in the first three categories.

The immediate source of the uranium concentrated in marine black shales was sea water. Interpretations that quantitatively relate the uranium content of shale to the uranium content of the sea water in which the shale was deposited, however, have little basis in fact; it is concluded that ancient sea water did not contain significantly more or less uranium than modern sea water, about 3 parts per billion of uranium. The second-order interpretation that granites or other types of rock yielded abnormally large amounts of uranium to blackshale seas is even more tenuous and should not be invoked to explain high uranium content of black shales.

The uranium in marine black shales and muds probably was concentrated in several forms and by several processes, but organic matter is directly or indirectly responsible for concentrating most of the uranium. Marine shale without organic matter generally contains 0.0001 to 0.0004 percent uranium, most of which is held in the small fraction of resistate minerals such as zircon and sphene, and some of which is held by ion exchange in clay minerals. If the shale contains 2 or more percent organic carbon, it is here termed "black shale," and its uranium content generally is from a few to as many as 250 times greater than that of noncarbonaceous marine shale.

Living plants and animals accumulate only very small amounts of uranium in their tissues, and, therefore, do not enrich a sediment in uranium by being buried and preserved with it. Some decomposition products of plant organisms can sorb uranium from solution so that the resulting material contains from 0.01 to as much as several percent uranium. This applies to solid substances such as partially decomposed fragments in peat and, more particularly, to the soluble organic substances commonly termed humic acids. A large part of the uranium in many marine black shales may have been sorbed from river and sea water by these substances before deposition.

Most of the organic matter deposited on a sea bottom is either directly reprocessed by organisms as food or is oxidized and destroyed. Where organic matter is deposited in quiet water, the oxidation process is soon terminated, decomposition is greatly slowed and largely limited to that by anaerobic bacteria, the water becomes increasingly acid and is fouled with hydrogen sulfide to become reducing ( $\mathrm{Eh}$ of -0.0 to -0.4 ), and much of the organic matter is preserved. As much as $199 \mathrm{cu} \mathrm{cm}$ of hydrogen sulfide per liter of water is present in the bottom water of some Norwegian fjords; the hydrogen sulfide probably reduces the uranium dissolved in this water from the hexivalent to the tetravalent state, whereupon the uranium is precipitated onto the organic-rich sediment, probably as submicroscopic grains of uraninite. The original uranium content of the sea water, which is generally only a few parts per billion $(0.000000 \mathrm{X}$ percent $)$, and the height of the water column invaded by hydrogen sulfide sharply limit the amount of uranium so precipitated. Intermittent circulation and consequent renewal of uranium-bear- 
ing water, alternating with periods of water stagnation and accumulation of hydrogen sulfide, would be necessary to explain sizeable additions of uranium to mud by this method. More than 50 percent of the uranium in some shales is believed to have accumulated by direct precipitation from sea water by the action of hydrogen sulfide.

Phosphate, generally in the form of carbonate-fiuorapatite nodules, is a common and distinctive component of many uraniferous black shales; in some black shales, phosphatic nodules and layers with 0.02 to 0.1 percent uranium contain much of the uranium in the shale, but in other uraniferous black shales the nodules contain only 0.001 to 0.003 percent uranium. The biogenic phosphate that settles into a relatively acid environment ( $\mathrm{pH}$ of 6.5 to 7.0 ) wherein black mud is accumulating is taken into solution and becomes concentrated to as much as $700 \mathrm{mg}$ per $\mathrm{cu} \mathrm{m}$ of water. A subsequent rise in $\mathrm{pH}$ toward $\mathbf{7 . 5}$ permits some phosphate precipitation, but if the water is largely depleted in uranium by hydrogen sulfide precipitation, the resulting phosphate contains very little uranium. Where the water has not been depleted in uranium or is undergoing some circulation and where phosphate precipitation takes place slowly, the phosphate deposited with the black mud may contain as much as 0.1 percent uranium. The amount of phosphate and the amounts of uranium in the phosphate and in the organicrich mud are dependent on a sensitive interplay of changes in the $\mathrm{pH}$ and $\mathrm{Eh}$ and on the availability of uranium and phosphate in solution in the water.

Based on the known and theoretical relations of uranium with other constituents, nine mechanisms of emplacement of uranium and the amounts attributable to each are given for a unit of the Chattanooga shale ( 0.0079 percent uranium), the black mud of a Norwegian fjord $(0.0060$ percent), an organic-rich mud from the Gotland deep of the Baltic Sea $(0.0010$ percent), and a phosphatic black shale of Pennsylvanian age $(0.0050$ percent $)$. Most of the uranium in the first two sediments probably was concentrated by direct precipitation by the action of hydrogen sulfide and by the sorption of uranium onto solid and soluble organic matter of the humic type. In the Baltic Sea mud, the uranium sorbed by soluble organic matter derived from land and by settling of partly decomposed plankton probably constitutes about one-half of the uranium in the mud; the other half is distributed fairly evenly among the clastic minerals and the phosphate, with only very minor amounts attributable to hydrogen sulfide precipitation. Most of the uranium in the phosphatic black shales of Pennsylvanian age is in the phosphate, with the solid and soluble organic matter of the humic type containing much of the remainder.

\section{INTRODUCTION}

Sources in the United States for a large supply of uranium were unknown when the need for this metal for nuclear weapons became apparent in 1943. This need instigated an intensive and extensive 10-year search for a domestic supply and resulted in meeting military requirements and the anticipated needs for uranium for peaceful uses of atomic energy.

Early in the search, black shale was investigated as one of the possibilities for a source of large quantities of uranium. Concentrations of uranium in ma- rine black shales in excess of 0.1 percent had been known for half a century (Nordenskiöld, 1893) from descriptions and analyses of kolm lenses in the alum shales of southern Sweden (see also Larsson, 1919; Munthe, Westergard, and Lundquist, 1928). For many years, the only lead-uranium age determination made on a sedimentary rock was one made on kolm samples from these shales of Late Cambrian age (Holmes, 1931). Abnormally high radioactivity of another marine black shale, the Dictyonema shale of Ordovician age in Estonia and Russia, was also known from papers by Orlov and Kurbatov (1934-36) and by Glebov (1941). The generally greater abundance of uranium in marine carbonaceous rocks, as compared to other sedimentary rock types, was established as a result of radioactivity determinations on hundreds of rock samples from the United States by Beers and Goodman (1944) and by Russell (1944).

Numerous marine black shales of tremendous tonnages and wide distribution throughout the United States were known. One of the logical steps to meet the urgent demand for uranium during the latter part of World War II was to search for black shale from which a large amount of uranium could be produced. This search was in large part a reconnaissance that involved field checking of outcrops of black shale by means of Geiger-Müller counters and, later, scintillation counters. No body of shale from which uranium can be economically recovered was located during these investigations nor during subsequent detailed studies of the more uraniferous shales. Discoveries in the period of 1949-55 of large uranium deposits in sandstones, conglomerates, and veins, which contain 10 to 100 times more uranium per unit of rock than is known in black shales, practically eliminated interest in black shale as a source of uranium.

The purpose of this report is twofold: (a) To review briefly the geologic and geochemical investigations conducted during the period 1944-57 on the amounts and distribution of uranium in the black shales in the United States; (b) to assemble and evaluate the geologic and geochemical information that directly or indirectly pertains to the origin and localization of uranium in marine black shale.

The origin of uranium in shale is a complex subject that is far from being completed understood; thus, this report is a progress report on the status of current knowledge. In general, the stratigraphic distribution and lithologic associations of uranium in black shales are known, and the possible and probable processes and factors involved in the concentration of uranium in black shale have been deduced. But many additional studies, particularly of the geochemical 
type, are needed to determine precisely the quantitative values and limits applicable in the chemical processes known to concentrate uranium in the environments of deposition of marine black shale.

\section{ACKNOWLEDGMENTS}

This report was prepared as a part of a general study by Geological Survey personnel on geologic problems involving the genesis and distribution of uranium that was sponsored by the Division of Raw Materials of the U.S. Atomic Energy Commission. The author wishes to acknowledge especially the help and guidance of William S. Twenhofel, Curt Teichert, Louis C. Conant, and James D. Vine in the development of ideas and in the preparation of this paper.

\section{WHAT IS "BLACK SHALE"?}

No precise definition of the term "black shale" would satisfy the requirements as might be set forth by each of the several thousands of geologists who frequently use the term. "Black shale" is similar to the term "sandstone," in that both refer to rocks of widely differing origins, chemical compositions, mineralogical suites, grain sizes, colors, and other descriptive characteristics. Defined in its most general sense, "black shale" is simply a dark-colored fine-grained clastic sedimentary rock. Most geologists would also include as additional parts of this definition the characteristic of abundant organic matter and the limitation of grain size to silt and clay sizes; inclusion of such additional restrictive items as the fissility of the rock, the specific color, the ratio of quartz to clay minerals, the minimum amount of organic matter, and the type of organic matter would be unacceptable to many geologists because it would exclude many rocks that have long been known as black shales.

As a lithologic term, "black shale" must be defined as that large class of sedimentary rocks composed chiefly of mineral grains of clay and silt size and containing sufficient organic matter, iron sulfide, or manganese oxide to give the rock an overall darkgray to black color. Within this class of rocks, several tens of types of black shales have been differentiated in a general or a precise fashion, depending on the particular constituent or constituents of primary interest. Thus, terms such as "humic shale," "oil shale," "graptolitic shale," "alum shale," "euxenic shale," "sapropelite," "gyttja," and many others are commonly applied to particular shales.

Because most black shale owes its color and distinctiveness to finely disseminated organic matter, "carbonaceous shale" for all practical purposes may be generally taken to be synonymous with "black shale." The general term "bituminous shale," though still commonly used to indicate shale that will yield oil when heated to high temperatures, does not conform to the now generally accepted and more precise usage of the terms "bitumen" and "bituminous" as defined by Abraham (1945, p. 47-52); bituminous substances are largely the hydrocarbons soluble in carbon disulfide, including petroleums and native mineral waxes and asphaltites, and are only sparsely present and rarely recognized in carbonaceous shales.

Strictly speaking, the adjective "black" in the term "black shale" should mean that the rock is devoid of color or incapable of reflecting light. However, few if any black shales have the $\mathrm{N} 1$ or black value of the National Research Committee Rock-Color Chart (1948). Most black shale is actually dark gray (N3), or grayish black (N2), and dark hues of brown (5YR 2/1) and olive (5Y 3/2-2/1) are not uncommon. Shale lighter in color than the values given above should be excluded from the general class of black shale. The dark color of most shale is imparted largely by the disseminated carbonaceous matter, and, in order to comply with the color restriction just given, only carbonaceous shale containing 2 or more percent organic carbon by weight should be classed as black shale.

The lithologic term "shale" must also be used in a loose sense because of its common, widespread, and long-term usage, particularly in studies of well cuttings, to indicate any fine-grained unmetamorphosed sedimentary rock. The connotation of fracture habit, or fissility, whether this feature is explained by mass grain orientation, minute lamination, or secondary structural causes, can no longer be considered definitive and distinctive. Thus "shale" is synonymous with "mudstone," and, therefore, includes siltstone and claystone; the term is not used, of course, to describe those fine-grained rocks that are composed largely of carbonate minerals.

Black shales of more than 200 formations were investigated in the United States from 1944 to 1957 during the search for uranium; a review of the stratigraphic relations of each of the black shales in these formations only emphasizes the diversity of occurrences and origins of the rocks included under the general term "black shale." This diversity is exemplified by comparing (a) a black shale parting less than 1 inch thick in the Salem limestone of Mississippian age in Missouri, (b) the black shale hundreds of feet thick in the Utica shale of Ordovician age in New York, (c) the black shale about 1 foot thick overlying the uppermost coal bed in the Cherokee shale of Pennsylvanian age in Kansas, and (d) the 
black shale ranging in thickness from a few inches to 25 feet that is associated with salt and gypsum of the Paradox formation of Pennsylvanian age in Utah. The term "black shale" becomes even more indefinite when applied in a general sense to a stratigraphic unit, as illustrated by a single black shale of large areal extent, the Chattanooga shale and many of its correlatives of Late Devonian age in the eastern and central United States. This black shale ranges from a fraction of an inch to several hundred feet in thickness; ranges in color through many shades of gray, olive gray, and brownish black, but rarely, if ever, is actually black; has a fracture pattern that is described in different places as massive, conchoidal, splintery, fissile, and paper thin; in different areas is interbedded with limestone, sandstone, phosphate, or chert; and has a content of organic matter ranging from less than 1 to more than 25 percent. These examples indicate only a few of the many stratigraphic, compositional, and genetic variations included under the term "black shale."

Similarly, modern accumulations of black mud, the progenitor of black shale, originate in a variety of environments such as swamps, lakes, tidal flats, coastal lagoons, fjords, the Black Sea, the Baltic Sea, and deep seas. The range in environments of deposition of black muds and the interpreted environments of deposition of black shales is large, but therein lies the currently used and most useful and practical basis for differentiating among black shales. The most easily discernible contrast among black shales is their marine or nonmarine origin. Marine black shales are characterized by uniform thickness and lithology over wide areas and by containing marine fossils or by being interbedded with and closely related to other lithologies having marine fossils. Nonmarine black shales are erratic in thickness and distribution, lack marine fossils, and generally are interbedded with or are lateral facies of sandstones and coals having primary structures and plant remains clearly identifiable as originating in a nonmarine environment. Subdivision of these two major types of black shales into more specific environmental types, such as eugeosynclinal, near-shore marine, estuarine, paludal, and lacustrine, are made on more explicit lithologic, paleontologic, and paleogeographic criteria.

\section{WHAT IS "URANIFEROUS BLACK SHALE"?}

Shale contains an average of a few parts per million ( 0.0003 or 0.0004 percent) uranium. Black shale contains more uranium than the average for all shale; it probably has an average of $8 \mathrm{ppm}$ (parts per mil- lion), and a general range of 3 to $250 \mathrm{ppm}$. Black shales of marine origin have only a slightly higher average than do all black shales; but, if the thick marine black shales deposited in geosynclinal areas are excluded, the average uranium content of marine black shales is about $20 \mathrm{ppm}$, or about 0.0020 percent.

The marine black shales hundreds to thousands of feet thick that accumulated in and marginally to the early Paleozoic eugeosynclinal and miogeosynclinal areas of the Eastern United States and the Mesozoic eugeosynclinal and miogeosynclinal areas of the Western United States rarely contain more than 0.002 percent uranium. The black shales that commonly contain more than 0.002 percent uranium are those shales only one to a few tens of feet thick of Paleozoic age that were deposited in epicontinental seas on the more stable cratonic areas of the Central and East Central United States. It is this latter kind of black shale that is referred to and discussed in this paper.

The uranium in black shale is a minor or trace element. The adjectives "uraniferous" and "uraniumbearing" have been used to describe shales containing relatively large amounts of uranium, much the same as "cupriferous," "chromiferous," and "vanadiferous" have been used to indicate comparable concentrations of other metals. As used in this report, "uraniferous" and "uranium-bearing" are applied only to those black shales generally containing in excess of $20 \mathrm{ppm}$, or 0.0020 percent, uranium.

\section{HISTORICAL REVIEW OF INVESTIGATIONS FOR URANIFEROUS BLACK SHALES}

The primary objective of all investigations reviewed here was to find black shale that could be economically utilized as a source of uranium. The investigations were generally of two types: reconnaissance studies, which involved a rapid field check of outcrops and some sample collecting to determine the radioactivity and uranium content of as many black shales as possible in the shortest length of time; and detailed geologic studies, to determine the stratigraphic, lithologic, and geochemical factors controlling uranium distribution in shale.

\section{INVESTIGATIONS, 1944-47}

During the period from early 1944 to 1947 , the Geological Survey was commissioned by the U.S. Army's Manhattan Engineer District, the forerunner of the Atomic Energy Commission, to conduct extensive reconnaissance studies to find uranium-bearing black shales. The geologic literature on black shales in the United States was reviewed, and the described out- 
crops of scores of marine black shales were checked in the field for their radioactivity by means of GeigerMuller counters. The names of the individuals who accomplished this early field reconnaissance, and who submitted informal progress reports which guided subsequent investigations, are here recorded for their rarely acknowledged part in the search for uraniferous black shales: K. G. Brill, Jr., A. P. Butler, Jr., C. W. Chesterman, S. E. Clabaugh, W. H. Hass, P. F. Narten, J. M. Nelson, W. W. Rubey, A. L. Slaughter, and E. V. Stratton.

No black shale was found during these early reconnaissance studies that equals in uranium content the Swedish shale, which contains from 0.020 to 0.030 percent uranium; of all the shales tested and otherwise evaluated, the Chattanooga shale of the Southeastern United States and the black shales of Pennsylvanian age in Kansas and Oklahoma have the highest uranium content of United States shales, generally between 0.005 and 0.010 percent. Many other shales in the United States were tested after 1947, but, as potential sources of uranium, none have been found that have the combined high uranium content and mining practicability of the black shale beds in the Chattanooga and those of Pennsylvanian age. The following important conclusions were formulated during these early studies to locate shale of high uranium content: (a) Uranium content is generally greater in marine than in nonmarine black shales; (b) uranium content increases with increasing organic matter; (c) phosphatic nodules in black shales have a high uranium content; (d) uranium content is greater in shales deposited slowly.

\section{INVESTIGATIONS, $1947-52$}

A second phase of investigations for uraniferous black shale in the United States encompasses the period 1947-52, when the U.S. Geological Survey conducted detailed field studies of the Chattanooga shale and made additional reconnaissance investigations for uraniferous shale, mainly in the Western States and Alaska. These and later studies by the Geologcial Survey were made on behalf of the Division of Raw Materials and of the Division of Research of the U.S. Atomic Energy Commission.

During this second period, a large Geological Survey field party, under the general direction of $\mathrm{L}$. C. Conant, conducted detailed stratigraphic studies and a widespread, systematic sampling program on the Chattanooga shale, mainly in central Tennessee but also in southern Kentucky and northern Alabama. More than 400 outcrops of Chattanooga shale were studied during the course of these investigations, and

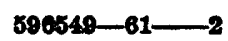

about 3,000 samples were collected for uranium determinations. The objectives of this work for the Atomic Energy Commission were to study the shale geologically, to evaluate it as a potential source of uranium, and, consequently, to designate the area or areas where the shale contains the most uranium which could be mined most economically; an area near Center Hill Reservoir in DeKalb and White Counties, Tenn., was so designated. The following geologists, all of the Geological Survey, contributed materially to this phase of work: Andrew Brown, L. C. Conant, W. H. Hass, W. A. Heck, T. M. Kehn, R .A. Laurence, W. H. Monroe, R. C. Robeck, R. E. Smith, and V. E. Swanson The following papers are an outcome of this work: A summary (Swanson, 1953) and a detailed description (Brown, 1956) of some of the mineralogic and stratigraphic associations of uranium in the Chattanooga shale; an interpretation (Conant, 1956) of the environment of deposition of the shale as related to uranium concentration; a review of the stratigraphy of the Chattanooga shale and overlying Maury formation, and of the age relations of the units in these formations as based on conodonts (Hass, 1956) ; and a detailed description of the distribution, lithology, and interpreted sedimentologic and paleogeographic conditions of the Chattanooga shale in the southeastern United States (Conant and Swanson, in press).

Chemical studies of the Chattanooga shale, aimed at developing uranium-extraction methods, were conducted by the Battelle Memorial Institute at Columbus, Ohio, and by the Oak Ridge National Laboratory of the U.S. Atomic Energy Commission; the results of these studies have not been made publicly available.

Concurrent with this study of the Chattanooga shale, a widespread reconnaissance search for uraniferous shale was conducted by the Geological Survey in the Western United States, under the general direction of N. M. Denson. Eighty formations containing black shale were investigated in 10 Western States, and about 380 samples were collected for radioactivity and uranium determinations. The results of this reconnaissance were reported by Duncan (1953); Duncan's report is based on the work of the following geologists: G. O. Bachman, N. M. Denson, D. C. Duncan, J. R. Gill, W. J. Hail, J. D. Love, G. W. Moore, C. B. Read, J. I. Simmons, and J. D. Vine. Excluding the phosphorites in the Phosphoria formation and 2 hydrothermally enriched shale units in Colorado, 12 formations have black shale units con- 
taining a maximum of 0.003 to 0.005 percent uranium; outcrop samples of shale from the Heath formation of Mississippian age in Montana contain a maximum of 0.006 percent uranium; and a few beds, each less than 1 foot thick, in the Hartville formation of Permian, Pennsylvanian, and Mississippian(?) age in the subsurface of southeastern Wyoming and western Nebraska, contain 0.010 to 0.019 percent uranium.

Similar reconnaissance in Alaska (White, 1952; Wedow, 1954) revealed several Precambrian and Paleozoic black shales containing 0.001 to 0.003 percent uranium, but only the phosphatic black shale near the base of the Calico Bluff formation of Mississippian age was found to contain more, generally between 0.003 and 0.006 percent uranium.

During this same period, Gott and Hill (1953) investigated the radioactivity in oil fields of southeastern Kansas and reported on the radioactivity of the Paleozoic black shales as indicated by the logs and samples of the wells studied.

Papers by Bain (1950, p. 291-292) and by McKelvey and Nelson (1950) summarize the general characteristics of uranium-bearing marine black shales known at the time of publication. The review by McKelvey and Nelson of general associations and probable origins of uranium in black shale served as an important guide in planning and executing subsequent black shale studies.

During the period 1947-52, the American Petroleum Institute sponsored a study at the Massachusetts Institute of Technology on the possible role of radioactivity in the transformation of organic materials into petroleum hydrocarbons. As a result of this study, the observed associations and the probable genetic relations of uranium to organic material and phosphate were summarized by Whitehead (1954) for several black shales, including the Antrim shale of Michigan, the Cherokee shale of Pennsylvanian age in Oklahoma, and the "Miocene nodular shale" of California.

\section{INVESTIGATIONS, 1952-57}

The third phase of studies of uraniferous black shale, extending from 1952 to 1957 , included a variety of more specialized geologic studies by Federal organizations, State geological surveys, and several university groups. Early in this period, existence was established of ample supplies of uranium ore within the United States, especially in sandstone ore of the Colorado Plateau that contains 0.1 or more percent uranium. The extensive reconnaissance studies of black shale had fairly certainly established that the United States lacks black shale that has a uranium content exceeding 0.01 percent and that can be mined cheaply. Studies of black shale during the period 1952-57 were thus largely devoted to analysis of existing information and to special field and laboratory studies designed to investigate the geologic factors affecting the distribution of uranium in shale.

The Chattanooga shale field investigations were continued by the Geological Survey until 1955; these included a core-drilling program, centered mainly in DeKalb County, Tenn. (Kehn, 1955), to determine exact thicknesses of overburden and of the shale and to provide data for calculating reserves in areas designated as possible mining sites. Some additional study on the stratigraphic distribution of uranium in the Chattanooga shale in eastern Tennessee, northwestern Georgia, and northeastern Alabama was made by Glover (1959). Laboratory studies on the lithologic and chemical associations of uranium in the Chattanooga shale (table 2) were made during this period (Deul and Breger, 1954; Breger and Schopf, 1955; Deul, 1957). The U.S. Bureau of Mines (1954) conducted tests in cooperation with the U.S. Atomic Energy Commission to determine the percentage and characteristics of oils retorted from the Chattanooga shale.

Contracts to conduct research on the Chattanooga shale were given by the U.S. Atomic Energy Commission to: (a) Pennsylvania State University, to determine the mineralogic and petrographic associations of uranium in shale (work directed by T. F. Bates; see Bates and others, 1956; Bates and Strahl, 1957) and to determine the chemical nature of the organic matter in shale and its association with uranium (work directed by C. R. Kinney; see Kinney and Schwartz, 1957) ; (b) the University of Tennessee, for a detailed study of the stratigraphic distribution of uranium (work directed by P. B. Stockdale and H. J. Klepser; see Stockdale, 1955; Klepser, 1957) ; and (c) Columbia University, for metallurgical studies of uranium extraction from shale (work directed by M. D. Hassialis; see Pollara and others, 1958).

During the period 1952-57, the U.S. Geological Survey completed special studies on the distribution of uranium in the following shales: (a) The Sharon Springs member of the Pierre shale of Late Cretaceous age in South Dakota, Nebraska, Colorado, and Kansas (Dunham, 1954, p. 157-158; Tourtelot, 1956; Kepferle, 1959; Landis, 1959) ; (b) the Eagle Ford shale of Late 
Cretaceous age in Texas (Eargle and Hollingsworth, 1958); (c) the several thin black shale layers in the cyclothems of Pennsylvanian age in southeastern Kansas and northeastern Oklahoma (Danilchik and Hyden, 1956); (d) the Chattanooga and the Woodford shales and the black shale in the Arkansas novaculite, all of Late Devonian and Early Mississippian age, in Oklahoma, Arkansas, and Kansas (Landis, 1958) ; (e) the black shales of Pennsylvanian age in southern Illinois (Patterson, 1955), southwestern Indiana (Snider, 1954a), Ohio (Snider, 1954b), eastern Kentucky (Welch, 1953a), southern West Virginia and Virginia (Snider, 1953), northern West Virginia (Patterson, 1954a), and Pennsylvania (Welch, 1953b; Patterson, 1954b; and Ferm, 1955). During this same period, Mapel $(1956 \mathrm{a}, \mathrm{b})$ reported on the uranium content of about 150 samples from 80 outcrops of black shale representing 22 formations in 5 Western States.

Several summaries were published by the Geological Survey during this period. Summaries of the general characteristics and of ideas on the genesis of uraniumbearing shales were presented (McKelvey, 1955, p. 14 16 ; McKelvey, Everhart, and Garrels, 1955, p. 514 520). The uranium contents of the marine black shales in the United States were reviewed by Swanson (1956), who later described the relation of the oil yields to the uranium contents of some of these shales (Swanson, 1960). An annotated bibliography of papers on the geology of uranium-bearing marine black shales in the United States was compiled by Fix (1958).

The State Geological Survey of Illinois made radioactivity and some uranium determinations on 175 samples of Paleozoic black shales, most of them of Pennsylvanian age, taken from outcrops in Illinois (Ostrom and others, 1955). A statistical analysis of the areal distribution of radioactivity in a black shale unit overlying the "No. 6 coal" of Pennsylvanian age in western and southern Illinois was made by Krumbein and Slack (1956). The uranium contents of the phosphatic nodules present in some of these Pennsylvanian black shales were reported for shales in Kansas (Runnels, Schleicher, and Van Nortwick, 1953) and in Illinois (Ostrom and others, 1955).

This review does not include the results of the Geological Survey's extensive studies of the phosphorite and black shale in the Phosphoria formation of Permian age in southeastern Idaho and adjacent States. Reports resulting from these studies, which were under the general direction of V. E. McKelvey, and reports on other uranium-bearing phosphorites, were listed and annotated by Curtis (1957). Sheldon (1959) presented interpretations of the geochemical conditions prevailing during deposition of the Phosphoria formation.

\section{SUMMARY OF INVESTIGATIONS, 1944-57}

More than 200 formations in the United States made up entirely or partly of black shale units, ranging from Precambrian to Tertiary in age, were checked for their radioactivity during the period 1944-57. Eight to ten thousand samples of black shale were collected from about 100 of these formations and fluorometrically analyzed for their uranium content. Additional chemical determinations (for example, for phosphate, organic carbon, and sulfur) were made on several hundred of these samples. The oil yields, based on destructive distillation tests, were determined for more than 500 black shale samples; semiquantitative spectrochemical analyses provided data on about 30 elements for each of more than 400 shale samples.

Thousands of outcrops, thousands of feet of well core, thousands of samples of drill cuttings, and many hundred gamma-ray logs were examined to find black shale that might be exploited as a source of uranium. Such a black shale should meet the following requirements: (a) It should contain more than 0.01 percent uranium; (b) it should be several feet thick and extend over an area of tens of square miles; (c) it should be situated so that it could be mined economically, preferably by open-pit methods. The vast exploratory program and all the analytical data reviewed above failed to reveal such a black shale in the United States. Some shales, for example the black shales in the Hartville formation of Permian, Pennsylvanian, and Mississippian(?) age in southeastern Wyoming and western Nebraska (J. D. Love, written communication, 1951; Duncan, 1953, p. 82-85) and possibly the Heath shale of Mississippian age of Montana (Mapel, 1956b, p. 233) and the Woodford shale of south-central Texas, contain more than 0.01 percent uranium but are located thousands of feet below the surface so as to make economical mining impossible. Similarly, selected samples of the Chattanooga shale in Tennessee and of the partial equivalent of the Chattanooga shale in northern Arkansas contained as much as 0.035 and 0.71 percent uranium, respectively, but the mass of shale from which these samples were taken contains about 0.005 percent uranium. 
The net result of the entire exploration program for uranium-bearing black shale was the determination that the Chattanooga shale of central Tennessee most nearly meets the requirements set forth above. Here, a unit of black shale 15 to 18 feet thick contains between 0.006 and 0.007 percent uranium and is present within a few hundred feet of the surface over many tens of square miles (Kehn, 1955). Certainly, neither the Chattanooga shale nor any other black shale in the United States will be mined within the near future for uranium, considering the large reserves of higher grade ores now known in the United States and other countries.

A major result of the search for uranium-bearing black shale was the great increase in knowledge of the geology of many formations. The thickness, distribution, lithofacies, and age of many formations containing black shale are now known in great detail; and many enigmatic problems on the paleontologic, mineralogic, and geochemical relations within black shales were solved or at least clarified.

\section{SOURCES OF URANIUM AND MECHANISMS OF ITS ENRICHMENT}

The exact chemical and physical forms and mineralogic associations of most of the uranium in marine black shale are not known. The amount of uranium in black shale can be determined precisely by fluorometric analysis and the uranium can be extracted by several chemical methods, but the chemical bonds, if any, of uranium with other elements in the shale are undetermined, and no uranium minerals have been separated or identified. Physical and chemical isolation of specific constituents of the shale, such as the organic or mineral matter, and chemical analyses of the isolates have not revealed any consistent relation between uranium and other constituents in the shale. By noting the sources of radioactive emanations on thin-section autoradiographs, it has been determined that much of the uranium is disseminated as submicroscopic specks through the shale, but, again, these point-sources of radiation have no consistent relation to other identifiable constituents. The failure to relate precisely the uranium with a uranium-bearing mineral or a specific shale component has resulted in several interpretations, some conflicting, on the manner of emplacement and factors controlling the distribution of uranium in shale.
Many kinds of observations have been made on the amount and distribution of uranium in shale. By using beta- and gamma-ray counters in the field and then relating laboratory uranium determinations on rock samples to field observations, geologists havo shown that the amount of uranium in some shales can be related to measurable characteristics of the strata, such as color, thickness of beds, grain size, and amounts of pyrite, organic matter, and carbonate minerals. From these and other features of the shales, they have concluded that the amount of uranium is related to rate of sediment deposition, chemistry of the water in which the sediment was deposited, and to several paleogeographic factors, such as the distance from and the uranium content of source rocks and the depth and rate of circulation of sea water. All these general relations have proved of some use in searching for uraniferous shale and in understanding the origin of uranium in shale. However, without exception, each generalization is of indefinite value because of numerous and major inconsistencies, either when applied to many shale formations or when applied quantitatively to a single black shale unit in a restricted area.

The problems of determining and quantitatively evaluating the sources and mechanisms of enrichment of uranium in shale are complex and largely unsolved. The complexities probably are the result of failure to recognize a combination of several sources, several processes of enrichment, and several forms of uranium in shale. The scope of the subject makes it impracticable to consider all problems connected with each of the many uraniferous shale formations; rather, representative examples and data are selected and discussed to provide a framework of knowledge pertaining to the origin of uranium in black shale and mud.

The following discussion is primarily a description of selected examples and data, accompanied by previously proposed interpretations and generalizations on uranium concentration. Each of the latter are evaluated critically in light of the information known on the examples given, with emphasis on the chemical environment of uranium deposition, and a conclusion is reached on the possible or probable quantitative importance of each in the origin of uranium in shale. The net result is not a series of final and conclusive answers, but is a summation of what is known; it can serve as basis for designing studies that may yield answers to many problems still remaining. 
EXAMPLES OF URANIUM-BEARING SHALE AND MOD

The origin of uranium in black shale probably can best be understood by studying modern sediments accumulating under conditions similar to those under which the uraniferous black shale accumulated. A second instructive approach involves laboratory experiments designed to duplicate as nearly as possible one or more of the probable conditions wherein uranium might have been concentrated in black shale. A third approach, which is the one most commonly used by the geologist and geochemist, is the detailed study of the shale itself, where the origin of the uranium is interpreted from the observed and determinable physical and chemical properties of the rock. Comparison and integration of the results of all three types of investigation are the basis for this report.
Tables 1 and 2 present in a brief form known chem. ical data believed to pertain to the concentration of uranium in marine black shales and muds. The general purpose of the tables is to allow ready comparison and evaluation of chemical factors that have been determined from four main categories of studies: (a) uraniferous marine black shale; (b) modern marine black muds whose uranium content is known; (c) the characteristics of the sea water in which these muds were deposited; and (d) relevant laboratory experiments on possible mechanisms of uranium concentration. The chemical constituents and properties given in the tables, and which will be discussed sequentially in the following pages, are: uranium, organic matter, hydrogen sulfide, phosphate, $\mathrm{pH}$ (acidity), Eh (oxidation-reduction potential), and salinity. 
TABLE 1.-Summary of chemical constituents and properties

\begin{tabular}{|c|c|c|c|c|}
\hline \multicolumn{2}{|c|}{ Uranium (U) in- } & \multirow{2}{*}{$\begin{array}{l}\text { Organic matter in } \\
\text { sediments } \\
\text { (percent) }\end{array}$} & \multicolumn{2}{|c|}{ Sulfides $\left(\mathrm{H}_{2} \mathrm{~S}, \mathrm{FeS}_{2}\right)$ in- } \\
\hline $\begin{array}{l}\text { Sediments } \\
\text { (percent) }\end{array}$ & $\begin{array}{l}\text { Waters } \\
\text { (parts per billion) }\end{array}$ & & $\begin{array}{c}\text { Sediments } \\
\text { (percent) }\end{array}$ & $\begin{array}{c}\text { Waters } \\
\text { (cu cm per liter) }\end{array}$ \\
\hline
\end{tabular}

URANIFEROUS MARINE BLACK SHALE

Chattanooga shale, upper unit of Gassaway member; central Tennessee; Late Devonian; about 5 ft thick

\begin{tabular}{|c|c|c|}
\hline $\begin{array}{l}0.0030-0.0120 \text {, over } \\
1,000 \mathrm{sq} \mathrm{mi} ; 0.0065- \\
0.0120, \text { over } 100 \mathrm{sq} \\
\text { mi; } 0.0079 \text {, average } \\
\text { over } 100 \mathrm{sq} \text { mi (modi- } \\
\text { fied from Kehn, 1955). }\end{array}$ & $\begin{array}{l}\text { 10-28, general range; } \\
\text { 20, general average } \\
\text { (modified from Bates } \\
\text { and others, 1956, } \\
\text { p. 38-40). }\end{array}$ & $\begin{array}{l}\text { Pyrite }\left(\mathrm{FeS}_{2}\right) \text { : } 7-22, \\
\text { general range; } 12, \\
\text { general average } \\
\text { (modified from Bates } \\
\text { and others, 1956, } \\
\text { p. 38-40). }\end{array}$ \\
\hline
\end{tabular}

MODERN MARINE MUDS

Black muds; Norwegian fjords; 2 in.-2 ft thick

\begin{tabular}{|c|c|c|c|c|}
\hline $\begin{array}{l}0.0013-0.0060,10 \\
\text { samples from } 9 \text { fjords; } \\
0.0036 \text {, average } 10 \\
\text { samples (table } 3 \text { ). }\end{array}$ & $\begin{array}{l}\text { 1-2, estimate for lower } \\
\text { saline waters; } 0.5-1, \\
\text { estimate for upper } \\
\text { fresh waters (p. 81-82). }\end{array}$ & $\begin{array}{l}6.4 \text { to } 39.7 \text {, samples } \\
\text { from } 9 \text { fjords (calcu- } \\
\text { lated, using } 1.7 \text { times } \\
\text { percent organic car- } \\
\text { bon); } 18 \text {, estimated } \\
\text { average (Str } \varnothing \mathrm{m}, 1936 \text {, } \\
\text { p. } 61-63 \text { ). }\end{array}$ & $\begin{array}{l}\text { All black mud samples } \\
\text { have strong } \mathrm{H}_{2} \mathrm{~S} \text { odor; } \\
>5 \text { percent } \mathrm{FeS}_{2} \text { esti- } \\
\text { mate on basis of } \\
\text { Valnesfjordvatn sam- } \\
\text { ple (Strøm, 1936, } \\
\text { p. } 60 ; 1937, \text { p. } 11 \text { ). }\end{array}$ & $\begin{array}{l}\mathrm{H}_{2} \mathrm{~S} \text { present in bottom } \\
\text { water of many fjords } \\
\text { (free oxygen absent), } \\
\text { commonly tens of feet } \\
\text { above bottom; maxi- } \\
\text { mum } 199.5 ; 5-10 \text { com- } \\
\text { mon (Strøm, 1936, } \\
\text { p. 52; 1948). }\end{array}$ \\
\hline
\end{tabular}

Black and gray muds; Baltic Sea, vicinity of Gotland; 10-16 in. thick

\begin{tabular}{|c|c|c|c|c|}
\hline $\begin{array}{l}0.00022-0.00103,10 \\
\text { samples from } 3 \text { cores; } \\
0.00048 \text {, average } 10 \\
\text { samples (table } 3 \text { ). }\end{array}$ & $\begin{array}{l}\text { 1.2-5.9, lower waters; } \\
\text { 3.2, estimated aver- } \\
\text { age, lower waters. } \\
0.8-2.0 \text {, upper waters; } \\
\text { 1.4, estimated aver- } \\
\text { age, upper waters. } \\
\text { (Koczy, Tomic, and } \\
\text { Hecht, 1957, p. 90.) }\end{array}$ & $\begin{array}{l}\text { 8-10, maximum, deep } \\
\text { east of Gotland } \\
\text { (Gripenberg, 1955, } \\
\text { p. 305); the "content } \\
\text { of organic matter [in } \\
\text { the samples] is very } \\
\text { high" (Koczy, Tomic, } \\
\text { and Hecht, 1957, } \\
\text { p. 91). }\end{array}$ & $\begin{array}{l}\text { "[The samples] have a } \\
\text { high eontent of iron } \\
\text { sulfide, are black, and } \\
\text { distinctly smell, often } \\
\text { strongly, of hydrogen } \\
\text { sulfide" (Koczy, } \\
\text { Tomic, and Hecht, } \\
\text { 1957, p. 91). }\end{array}$ & $\begin{array}{l}\mathrm{H}_{2} \mathrm{~S} \text { rarely present in } \\
\text { bottom waters (Gran- } \\
\text { quist, } 1932 \text {; Strøm, } \\
1955, \text { p. 366). Bottom } \\
\text { waters where samples } \\
\text { collected contain } 1.03 \\
\text { to } 1.50 \mathrm{cu} \text { cm oxygen } \\
\text { per liter, which is about } \\
20 \text { to } 25 \text { percent of } \\
\text { oxygen in normal sea } \\
\text { water (Koczy, Tomic, } \\
\text { and Hecht, 1957, } \\
\text { table } 2 \text { ). }\end{array}$ \\
\hline
\end{tabular}

MODERN OCEANS

\begin{tabular}{|c|c|c|c|c|}
\hline $\begin{array}{l}\text { 0.0001-0.0003, deep-sea } \\
\text { sediments (Koczy, } \\
1956, \text { p. } 95)\end{array}$ & $\begin{array}{l}1-3.5 \text {, general range; } 3 \text {, } \\
\text { average value used in } \\
\text { this report (p. } 81 \text { ). }\end{array}$ & $\begin{array}{l}<1.0 \text {, estimate (Sver- } \\
\text { drup, Johnson, and } \\
\text { Fleming, 1942, } \\
\text { p. 1008). }\end{array}$ & $\begin{array}{l}\mathrm{H}_{2} \mathrm{~S} \text { very rarely present; } \\
\text { sediments generally } \\
\text { oxygenated. }\end{array}$ & $\begin{array}{l}\text { General range of oxygen, } \\
\text { though highly variable } \\
\text { and dependent on } \\
\text { depth, latitude, and } \\
\text { seasons, is between } 4.0 \\
\text { and } 7.0 \mathrm{cu} \text { cm per liter. }\end{array}$ \\
\hline
\end{tabular}


controlling the concentration of uranium in marine black shales and muds

\begin{tabular}{|c|c|c|c|c|}
\hline \multicolumn{2}{|c|}{ Phosphate $\left(\mathrm{P}_{2} \mathrm{O}_{6}\right)$ in- } & Acidity \\
(pH) \\
$\begin{array}{c}\text { Sediments } \\
\text { (percent) }\end{array}$ & $\begin{array}{c}\text { Waters } \\
\text { (mg per cu m) }\end{array}$ & $\begin{array}{c}\text { Oxidation-reduction } \\
\text { potential } \\
\text { (Eh) }\end{array}$ & $\begin{array}{c}\text { Salinity } \\
\text { (parts per thousand) }\end{array}$ \\
\hline
\end{tabular}

URANIFEROUS MARINE BLACK SHALE-Continued

Chat tanooga shale, upper unit of Gassaway member; central Tennessee; Late Devonian; about 5 ft thick-Continued

\begin{tabular}{|l|l|l|}
\hline $0.1-0.8$, general range; \\
0.3, general average \\
(Brown, 1956; written \\
communication, \\
$1958)$.
\end{tabular}

MODERN MARINE MUDS-Continued

Black muds; Norwegian fjords; 2 in.-2 ft thick-Continued

\begin{tabular}{|c|c|c|c|c|}
\hline $\begin{array}{l}0.14-0.36,9 \text { black mud } \\
\text { samples from } 7 \text { fjords; } \\
0.25 \text {, estimated aver- } \\
\text { age (Strøm, 1936, } \\
\text { p. } 61-63 \text { ). }\end{array}$ & $\begin{array}{l}\text { 700, maximum in bot- } \\
\text { tom waters; about } \\
300, \text { average in bot- } \\
\text { tom waters of } 9 \text { fjords } \\
\text { (table 3) (Strøm, } \\
1936 \text { ). }\end{array}$ & $\begin{array}{l}\text { 6.89-7.48 in bottom } \\
\text { waters of } 9 \text { fjords } \\
\text { (table } 3) ; 7.0 \text {, esti- } \\
\text { mate average, } 0-10 \\
\text { feet above black } \\
\text { muds. }\end{array}$ & $\begin{array}{l}-0.1-0.4 \text {, in bottom } \\
\text { waters, estimate as } \\
\text { indicated by } \mathrm{H}_{2} \mathrm{~S} \\
\text { concentration ( } \mathrm{Str} \varnothing \mathrm{m} \text {, } \\
\text { 1936). }\end{array}$ & $\begin{array}{l}\text { 24.63-34.81, in bottom } \\
\text { waters; 34.40, average } \\
\text { of bottom waters } \\
\text { (table } 3 \text { ) (Strøm, 1936) }\end{array}$ \\
\hline
\end{tabular}

Black and gray muds; Baltic Sea, vicinity of Gotland; 10-16 in. thick-Continued

\begin{tabular}{|c|c|c|c|c|}
\hline Not known & $\begin{array}{l}225 \text {, maximum in bot- } \\
\text { tom waters of Gotland } \\
\text { deep (Buch, 1932); } \\
\text { about } 100 \text {, estimated } \\
\text { average of bottom } \\
\text { waters. }\end{array}$ & $\begin{array}{l}\text { About } 7.0 \text { in deep } \\
\text { waters of Baltic; } 8.0 \\
\text { in surface waters } \\
\text { (Segerstråle, 1957, } \\
\text { p. 766). }\end{array}$ & $\begin{array}{l}0.0-+0.1 \text { in bottom } \\
\text { waters, estimate as } \\
\text { indicated by oxygen } \\
\text { concentration (Koczy, } \\
\text { Tomic, and Hecht, } \\
1957, \text { p. } 90 \text { ). }\end{array}$ & $\begin{array}{l}\text { 10.65-13.69, in bottom } \\
\text { waters; } 11.95 \text {, average. } \\
\text { in bottom waters } \\
\text { (table } 3 \text { ). }\end{array}$ \\
\hline \multicolumn{5}{|c|}{ MODERN OCEANS-Continued } \\
\hline $\begin{array}{l}\text { Probably <0.2 (Sver- } \\
\text { drup, Johnson, and } \\
\text { Fleming, 1942, } \\
\text { p. 992). }\end{array}$ & $\begin{array}{l}\text { 100, mean for ocean } \\
\text { water (Smirnov, 1958, } \\
\text { fig. 1); surface waters } \\
\text { rarely contain more } \\
\text { than } 50 \text {. Maximum } \\
\text { values generally at } \\
500-1,000 \text { m depth, } \\
\text { where general range } \\
\text { is 100-300 (Barnes, } \\
1957 \text { ). }\end{array}$ & $\begin{array}{l}\text { About } 8.0 \text {, in open sea, } \\
\text { with general range } \\
7.8-8.4 \text {. }\end{array}$ & $\begin{array}{l}+0.1-+0.3, \text { generally } \\
\text { positive. }\end{array}$ & $\begin{array}{l}\text { 34.73, mean surface } \\
\text { salinity; salinities of } \\
\text { deep waters slightly less } \\
\text { (Fleming, } 1957, \text { p. } 89 \text {, } \\
\text { 105). }\end{array}$ \\
\hline
\end{tabular}


TABLE 2.-Laboratory experiments in preoipitating and in concentrating uranium

Uranium in waters

Concentrations in experiment solutions, usually as uranyl sulfate or uranyl nitrate, generally $>200,000 \mathrm{ppb}$. Garrels (1955) and Miller (1958) reviewed the chemistry of uranium in natural waters.

Organic matter in sediments

Uranium in solution is sorbed and firmly fixed by organic substances.

1. By solid organic matter:

a. Peat and lignite, after being placed in uranyl solution, contained 1-10 percent uranium (Szalay, 1954).

b. Wood, peat, coal, and other carbonaceous substances extracted different amounts of uranium from solution; peat, lignite, and subbituminous coal extracted 98.0-99.9 percent of available uranium (Moore, 1954).

c. Subbituminous coal, after being placed in uranyl solution, contained 31.8 percent uranium with recognizable uraninite; similar results obtained and with degraded spruce wood (I. A. Breger and R. T. Moore, written communication, 1955).

d. Samples of carbonaceous shales are capable of irreversibly sorbing uranium from urantum solutions (Tolmachev, 1943).

e. Lignin or humic fractions of peat and lignitic wood firmly fix uranium extracted from solution (F. S. Barghoorn, written communication, 1956).

t. Lignite sorbed as much as $\mathbf{1 1 . 8}$ percent uranium dioxide from uranyl sulfate solution; maximum sorption in solution of pH 5-6 (Rozhkova, and others, 1958).

g. Uranium is sorbed from saline uranyl solutions by dead micro-organisms (Ewing, Drynan, and Gloyna, 1955).

2. By soluble organic substances:

a. Humic acids quickly extract large amounts of uranium from solution by ion exchange at pH 3-7 (Szalay, 1954, 1958).

b. Humic and fulvic acids readily take up uranium from uranyl solutions; amount depends on $\mathrm{pH}$; forms organo-metallic complex (Manskaya, Drozdova, and Emelyanova, 1956).

c. Uranium is reduced and precipitated from uranyl solutions by organic reagents, for example, ether (Gruner, 1952).

d. Soluble humic acid extract from peat withdraws uranium from a solution containing only $60 \mathrm{ppb}$ uranium (Vine, Swanson, and Bell, 1958).

e. Sorption capacity of humic acid is less than that of lignite; but humic acid sorbed 1-2 percent uranium dioxide from uranyl sulfate solution, with optimum $\mathrm{pH}$ between 5 and 6 (Rozhkova and others, 1958).

\section{Sulfides $\left(\mathrm{H}_{2} \mathrm{~S}, \mathrm{FeS}_{2}\right)$}

Uranium is reduced and precipitated as uraninite or amorphous pitchblende from acid uranyl solutions by introducing $\mathrm{H}_{2} \mathrm{~S}$ or iron sulfide minerals into the solution.

1. Pitchblende was dissolved with $\mathrm{HNO}_{3}$ and reprecipitated with $\mathrm{H}_{2} \mathrm{~S}$ at temperature of $30^{\circ} \mathrm{C}$ (Kessler, 1857).
2. $\mathrm{H}_{2} \mathrm{~S}$ was bubbled through uranyl sulfate solutions to saturation and, with ferrous iron as catalyst and pH 0.89-2.8, pitchblende precipitated (Gruner, 1952).

3. Pitchblende was precipitated from uranyl solutions saturated with $\mathrm{H}_{2} \mathrm{~S}$; no catalyst necessary (L. J. Miller and P. F. Kerr, written communication, 1954).

4. $\mathrm{H}_{2} \mathrm{~S}$ in natural gas is the reducing agent for precipitating insoluble tetravalent uranium compounds from uranyl solutions (Colorado School of Mines Research Foundation, 1957).

5. Pitchblende precipitated from several kinds of uranyl solutions by $\mathrm{H}_{2} \mathrm{~S}$, with varying temperature, pressure, uranium concentration, anion concentration, $\mathrm{pH}$, and time; precipitation shown to be likely within range of natural conditions (Miller, 1958).

6. Reduction and precipitation of uranium from uranyl sulfate and uranyl carbonate solutions by $\mathrm{H}_{2} \mathrm{~S}$, ferrous iron, and sulfide minerals at different concentrations and under different temperature and $\mathrm{pH}$ conditions (Rafalsky, 1958).

7. Black pitchblende is precipitated from uranyl solutions as crust on surfaces of pyrite and marcasite crystals (Gruner, 1952, p. 17).

8. Most of uranium in uranyl solution reduced and precipitated, probably as hydroxide, in presence of melnikovite; uranium hydroxide subsequently converted to uraninite, and melnikovite to its more stable form of pyrite (Gruner, Rosenzweig, and Smith, 1953, p. 9).

Phosphate $\left(\mathrm{P}_{2} \mathrm{O}_{3}\right)$

Oranium substitutes for calcium in carbonate fiuorapatite. Experiments resulting in coprecipitation of phosphate and uranium in combined form are not known.

1. Phosphate rock immersed in uranyl sulfate solution extracted 63 percent of uranium in solution (Moore, 1954).

2. "Carbonapatite," stirred in sea water enriched in uranium, extracted variable amounts of uranium, in some cases more than 50 percent, dependent on amount of "carbonapatite," amount of uranium in solution, and length of experiment (Bain, 1956, p. 54-58).

3. Sedimentary phosphorites sorb about 10 times more uranium from uranyl solutions than apatite crystals; the former contain as much as 3.0 and the latter 0.28 percent uranium dioxide (Rozhkova and others, 1958).

Acidity (pH)

Change in $\mathrm{pH}$ alone will not effect reduction or precipitation of uranium. Most solutions in experiments cited had $\mathrm{ph}<2.5$.

1. Optimum $\mathrm{pH}$ for sorption and concentration of uranium by humic acids is between 5 and 7 (Manskaya, Drozdova, and Emelyanova, 1956).

2. Uranium is reduced and precipitated by $\mathrm{H}_{2} \mathrm{~S}$ in $\mathrm{pH}$ range 2-8 (Miller, 1958, p. 530, 537).

3. Maximum uranium sorption by organic substances in solutions having $\mathrm{pH}$ between 5 and 6 (Rozhkova and others, 1958).

Oxidation-reduction potential (Eh)

Oxidizing conditions (positive Eh) probably existed initially in the solutions of all experiments cited to left; reducing conditions (negative $\mathrm{Eh}$ ) created in some by addition of 
TABLE 2-Laboratory experiments in precipitating and in concentrating uranium-Continued

$\mathrm{H}_{2} \mathrm{~S}$, iron sulfide, or organic substances to the solution, whereupon the uranyl (VI) ions were reduced and precipitated in the uranous (IV) form.

1. See "Sulfides $\left(\mathrm{H}_{2} \mathrm{~S}, \mathrm{FeS}_{2}\right)$ " above.

2. Reduction and precipitation of uranium in reducing environment created in uranyl solution by woody material (R. M. Garrels and A. M. Pommer, written communication, 1956).

\section{Salinity}

No experiments known where salinity conditions were duplicated to note effect on uranium sorption and precipitation. Roshkova and others (1958), p. 426) determined, however, that addition of great amounts of sodium, magnesium, and calcium ions to uranyl solutions does not change the uranium sorption capacities of organic substances, phosphorites, and other materials.

The Chattanooga shale was chosen as an example of a uraniferous shale because more data, both chemical and geologic, are available for this shale than for any other in the United States. The data are limited to that on the upper part of the Gassaway member of the Chattanooga shale because the thickness of the unit and the chemical data on it are similar to the available data on the modern sediments described.
The chemical composition of this part of the Chattanooga shale is:

[Based on analyses of two bulk samples from central Tennessee, as determined by the Battelle Memorial Institute of Columbus, Ohio, for the U.S. Atomic Energy Commission]

\begin{tabular}{|c|c|c|c|}
\hline Constituent & Percent & Constituent & Percent \\
\hline 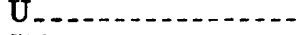 & 0.0079 & $\mathrm{P}_{2} \mathrm{O}_{5}$ & 0.38 \\
\hline $\mathrm{O}_{2-}$ & 48. 60 & S (sulfate) & .23 \\
\hline & 10. 35 & $\mathbf{S}$ (sulfide) & 6. 1 \\
\hline . & 9. 71 & $\mathbf{S}$ (organic) $\ldots$ & .87 \\
\hline & .65 & $\mathrm{CO}_{2-}$ & .39 \\
\hline $\mathrm{aO} \ldots$ & .97 & $\mathrm{H} \ldots \ldots$ & 1.6 \\
\hline $\mathrm{gO}_{\ldots} \ldots \ldots$ & 1. 37 & $\mathrm{C}$ (organic) & 13. 85 \\
\hline 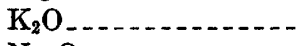 & 3. 68 & Loss on ignition & 23. 0 \\
\hline -......... & .36 & & \\
\hline
\end{tabular}

Much information is available on the chemistry of the sea water of modern basins of deposition. To the writer's knowledge, however, the amounts of uranium and other chemical constituents of the deposited black muds have been determined and the chemical regimen of the overlying waters is fairly well known for only two areas-the fjords of southern Norway and the Baltic Sea (table 3). Some data on the Chesapeake Bay (Jaffe and Hughes, 1953), on the Atlantic Ocean

TABLE 3.-Chemical data on bottom sediment and water in Norwegian fjords and in the Baltic Sea near Gotland

Norwegian fjords and channel

\begin{tabular}{|c|c|c|c|c|c|c|c|}
\hline Locality & \multicolumn{2}{|c|}{ Sediment (Str $\phi m, 1948$ ) } & \multicolumn{5}{|c|}{ Bottom waters (Str $\phi \mathrm{m}, 1936)$} \\
\hline $\begin{array}{l}\text { Indre Topdalsfjord. } \\
\text { Spdndeledspoll } \\
\text { Isefjoerford. } \\
\text { Hellefjord }\end{array}$ & \multirow{3}{*}{$\begin{array}{r}65 \\
18 \\
26 \\
70 \\
160 \\
160 \\
53 \\
34 \\
117 \\
81\end{array}$} & \multirow{3}{*}{$\begin{array}{r}0.0060 \\
.0050 \\
.0050 \\
.0040 \\
.0040 \\
.0035 \\
.0035 \\
.0020 \\
.0015 \\
.0013\end{array}$} & \multirow{3}{*}{$\begin{array}{r}65 \\
15 \\
20 \\
70 \\
160 \\
50 \\
35 \\
100 \\
80 \\
500\end{array}$} & \multirow{3}{*}{$\begin{array}{r}1 \text { about } 1 \\
5.42 \\
7.92 \\
40.72 \\
1199.5 \\
9.90 \\
11.6 \\
4.79 \\
\text { (3) }\end{array}$} & \multirow{3}{*}{$\begin{array}{c}60 \\
120 \\
362.5 \\
700 \\
>217 \\
530 \\
123 \\
515 \\
73 \\
30\end{array}$} & \multirow{3}{*}{$\begin{array}{l}7.48 \\
6.96 \\
7.05 \\
6.89 \\
6.90 \\
7.04 \\
7.34 \\
7.08 \\
7.46 \\
7.97\end{array}$} & \multirow{3}{*}{$\begin{array}{l}34.40 \\
33.08 \\
31.15 \\
33.26 \\
24.63 \\
32.43 \\
34.20 \\
29.87 \\
34.25 \\
35.21\end{array}$} \\
\hline $\begin{array}{l}\text { Mortensingord } \\
\text { Drammensfjord- }\end{array}$ & & & & & & & \\
\hline $\begin{array}{l}\text { Indre Oksefjord.-. } \\
\text { Norwegian channel (Skagerrak).. }\end{array}$ & & & & & & & \\
\hline
\end{tabular}

Baltic Sea

[Compiled from Koczy, Tomic, and Hecht (1957)]

Lat $58^{\circ} 35^{\prime}$ N., long $18^{\circ} 13^{\prime}$ E......

1 Strøm (1948).

Contains $3.2 \mathrm{cu} \mathrm{cm}$ oxygen per liter (Str $\phi \mathrm{m}, 1948)$.

Contains $7.04 \mathrm{cu} \mathrm{cm}$ oxygen per liter (Strøm, 1948).

$596549-61 \longrightarrow 3$ 
(for example, Urry and Piggot, 1941, and Holland and Kulp, 1954), and on some seas and lakes in and near the U.S.S.R. (for example, Kurbatov, 1936, and Kurbatov and Ermolaev, 1937) relate radioactivity to types of bottom sediment, but these studies are not strictly applicable for comparative purposes, either because they do not concern black muds or because of the paucity of specific information. The many reports on conditions of deposition of modern black muds are not reviewed here because no reference is made in them to the uranium content of the muds.

Strøm (1936) described excellently and in detail the bottom muds and waters of some thirty fjords on the coast of Norway. In a later note (1948) he gave the uranium content of the black mud and the amount of hydrogen sulfide in the overlying waters of nine of these fjords. In preparing the material for tables 1 and 3 , it was necessary to combine some not entirely analogous descriptions and chemical data from the two papers (table 3). For example, the samples for which the uranium data are given are not the same samples for which analyses for organic matter and phosphate are given. For this reason, properties and constituents of the muds and waters are compared and related only in a semiquantitative manner.

The descriptive and analytical data on the sediment and water of the Baltic Sea (tables 1,3) are primarily from a report by Koczy, Tomic, and Hecht (1957). Some of the data are from other reports, but because these data represent samples from different localities, they are used to indicate only in a general way the characteristics of the sediment and water in the southcentral part of the Baltic Sea in the vicinity of the island of Gotland.

The chemical characteristics of modern ocean water and sediment are shown in table 1 to enable the reader to contrast some of the abnormal characteristics of the bottom sediment and water of the fjords and the Baltic Sea with those of common ventilated sea water. The chemical composition of sea water and the chemical reactions postulated as taking place in sea water are grossly oversimplified in this report; but, as they affect the distribution and deposition of uranium, they are believed consistent with what is now known. Hutchinson's (1957) review of the complex interrelations among the chemical variables such as hydrogen sulfide, phosphate, $\mathrm{pH}$, and $\mathrm{Eh}$, concerns lake waters, but is applicable to many parts of the following discussions, and it has been used as a general reference.

Table 2 is a compilation of reported results of experiments on precipitating or concentrating uranium in the laboratory as they may be relevant to each of the several chemical constituents and properties listed.

The aqueous solutions in nearly all the laboratory experiments cited had uranium contents considerably greater than that of "average" sea water and of the water of the Baltic Sea and Norwegian fjords. The feasibility of uranium precipitation or sorption from natural waters by the mechanisms indicated in subsequent pages is, therefore, somewhat conjectural; but, until proved otherwise, these mechanisms are assumed to be effective in concentrating uranium from extremely dilute uranium solutions such as sea water, given enough time and an ample supply of water.

\section{SOURCES OF URANIUM}

The marine muds and black shales discussed in this report contain from 0.0002 to 0.0120 percent uranium.

The chemical and mineralogical form of the uranium in modern muds and in black shales is not known except that most of it is in a reduced or tetravalent state. Detailed studies of the Chattanooga shale were made by several laboratory groups in an attempt to determine the chemical and mineralogic associations of the uranium in the shale. Bates and Strahl (1957, p. 1311), after studies extending over several years and utilizing numerous chemical and mineralogic techniques, stated: "No evidence of a uranium mineral, even of 'electron microscopic' dimensions, has been observed, and the manner in which the uranium atoms are tied to other components in the rock has not been determined." This statement, in essence, summarizes present knowledge on the chemical and mineralogic state of uranium in the shale.

Microautoradiographs show that the uranium in marine black shales is thoroughly disseminated through the rock. The regional distribution of the uranium also is remarkably uniform. Uranium content of about 0.0090 percent was consistently found in 47 samples collected over a distance of 1 mile in central Tennessee from a bed of Chattanooga shale less than 1 inch thick. The lateral changes in uranium content are very small over hundreds, even thousands, of square miles of Chattanooga shale units several feet thick. This uniformity in uranium content and the high radioactivity as compared to other sedimentary rocks are the reasons why the Chattanooga and most other black shales are used as "marker beds" in interpreting subsurface stratigraphy over large areas by gamma-ray logs of wells. These observations support the now-unquestioned conclusions that the uranium in marine black shales was deposited at, or nearly at, the same time as the enclosing sediment and that the only logical source of this uranium was the overlying blanket of sea water. There is little doubt that most of 
the uranium in the muds of the Norwegian fjords and the Baltic Sea also is derived from the overlying water.

The conclusion that uranium in shale was derived from sea water has been the basis for a large variety of interpretations to explain the origin of uranium and the differences in uranium contents of black shales. Evidence supporting these interpretations ranges from specific and definitive to very indirect and ambiguous. The remainder of this report is devoted to an evaluation of these interpretations and the evidence for each. The general starting point for this evaluation is our knowledge concerning uranium in sea water.

\section{SOURCES AND CHEMICAL FORM OF URANIUM IN SRA} WATER

The major sources of uranium in sea water are the igneous, metamorphic, and sedimentary rocks that release their uranium to surface and ground waters as they are decomposed and disintegrated by weathering processes. Much of the uranium is dissolved in the ground and surface waters and is then transported to the sea in streams and rivers. An average content of these streams, both in the past and at present, may be assumed to be less than $1 \mathrm{ppb}$ (part per billion), or less than 0.0000001 percent uranium, on the basis of studies of modern streams by Fix (1956, p. 669), though Koczy $(1956$, p. 101) gives an average value of $1 \pm 0.5$ ppb uranium in river waters.

Some uranium is transported to the sea as a part of solid mineral particles such as zircon and sphene, which are highly resistant to chemical and mechanical breakdown. These heavy minerals generally are concentrated in the coarse clastic material of fluviatile and near-shore marine environments. They make up only a small fraction of 1 percent of most marine shales, and because they generally contain 0.05 percent or less uranium, these heavy minerals have less than $1 \mathrm{ppm}$ or less than 0.0001 percent uranium in the total volume of the Chattanooga shale; they probably contribute a similar small amount in the modern muds. The main mass of clastic minerals transported as solid particles to the sea, exclusive of the aforementioned resistates, generally contains so little uranium (1 or 2 $\mathrm{ppm}$ ) as to act as the major diluent in any uraniferous black mud accumulation.

The uranium dissolved in sea water may be present in several forms, depending mainly on the $\mathrm{pH}$ and Eh of the water (Garrels, 1955). In the normal slightly alkaline and oxidizing environment of sea water ( $\mathrm{pH}$ about 8.0, Eh about +0.1 ), practically all the uranium is in the hexavalent, or uranyl, form and is combined as carbonate, sulfate, and several other com- plex ions. These ions are highly soluble and consequently are widely distributed in sea water.

\section{URANIUM CONTENT OF MODERN SFA WATER}

The range in uranium content of modern ocean water is small, from about 0.1 to $5.9 \mathrm{ppb}$ (Karlik, 1939; Rona and Urry, 1952; Stewart and Bentley, 1954; Koczy, 1956; Rona, Gilpatrick, and Jeffrey, 1956; Koczy, Tomic, and Hecht, 1957) ; the content is in general dependent on depth, salinity, and position relative to the mouths of rivers. The average uranium content of sea water of normal salinity in the oceans today is $1.3 \mathrm{ppb}$ according to Koczy (1954, p. 122); 2 ppb (Baranov, Ronov, and Kunashova, 1957$, p. 3$) ; 2 \pm 1$ ppb as more recently proposed by Koczy (1956, p. 95) ; 2.8 ppb (Holland and Kulp, 1954, p. 198); and $3.3 \mathrm{ppb}$ as determined by Rona, Gilpatrick, and Jeffrey (1956, p. 700). For purposes of discussion in this paper, $3 \mathrm{ppb}$ of uranium, or 0.0000003 percent, will be used for the average amount of uranium in sea water.

The uranium content of samples of water from 7 stations in the Baltic Sea ranges from 0.77 to $5.9 \mathrm{ppb}$ (Koczy, Tomic, and Hecht, 1957, p. 86); the average content is between 1 and $2 \mathrm{ppb}$ uranium. The water of high salinity flowing into the Baltic from the North Sea contains $1.8 \mathrm{ppb}$ uranium, while the upper, less saline water that flows out of the Baltic contains 0.9 ppb.

The uranium content of water in the Norwegian fjords is not known. Estimates of the uranium content of this water can be made, however, by utilizing data on samples from Gullmarfjord on the west coast of Sweden (Hernegger and Karlik, 1935, p. 13; Karlik, 1939 , p. 11), from the Skagerrak (Karlik, 1939, p. 11; Koczy, Tomic, and Hecht, 1957, table 2), which is the body of marine water separating southeastern Norway, southwestern Sweden, and Denmark, and from rivers emptying into the Skagerrak and the Baltic Sea (Koczy, Tomic, and Hecht, 1957, table 1, p. 86, 94).

The hydrography and sediments of Gullmarfjord (lat $58^{\circ} 19^{\prime} \mathrm{N}$.; long $11^{\circ} 33^{\prime} \mathrm{E}$.) probably are similar to the cited Norwegian fjords for, as shown by available maps (Charts 72 and 73, 1:50,000 scale, Hydrographic Dept., Royal Board of Shipping and Navigation, Stockholm, Sweden), Gullmarfjord is comparable in general to other fjords in shape, area, and other geographic features. It has a maximum depth of 119 meters ( 390 feet), but if a threshold is present at the mouth of Gullmarfjord, it is ill defined and exceeds $\mathbf{1 0 0}$ feet in depth in places. The waters in this fjord contain $0.36 \mathrm{ppb}$ uranium at the surface, $1.1 \mathrm{ppb}$ 
at a depth of 60 meters (196.8 feet), and $1.5 \mathrm{ppb}$ at a depth of 100 meters (328 feet).

The Skagerrak water, which is the sea water entering and making up the saline bottom water of Gullmarfjord and most of the Norwegian fjords discussed here, contains only about $0.45 \mathrm{ppb}$ uranium at a depth of 5 meters (16.4 feet) according to Karlik (1939); the water contains $1.5 \mathrm{ppb}$ at a depth of 15 meters ( 49.2 feet) and $1.2 \mathrm{ppb}$ at a depth of 120 meters (393.6 feet) according to Koczy, Tomic, and Hecht (1957); and 1.2 and $1.5 \mathrm{ppb}$ of uranium for depths of 400 meters (1,312 feet) and 500 meters (1,640 feet), respectively, according to Karlik (1939). From these analyses it is reasonable to assume that the uranium content of the saline water entering the Norwegian fjords is between 1 and $2 \mathrm{ppb}$.

The uranium content of rivers flowing into and making up much of the surface water in the Norwegian fjords may be comparable to the uranium content of nine rivers draining regions of granitic and gneissic rocks and emptying into the Baltic Sea and the Skagerrak. These rivers contain from 0.2 to 0.7 $\mathrm{ppb}$ uranium, and average $0.5 \mathrm{ppb}$ (Koczy, Tomic, and Hecht, 1957, table 1, p. 86, 94). The Orekils River, which empties into Gullmarfjord, contains $0.5 \mathrm{ppb}$ uranium and is responsible for the low uranium content of the surface water (see above) of Gullmarfjord. Most of the rivers flowing into the Norwegian fjords drain similar terranes (Str $\phi \mathrm{m}, 1936$, p. 17-20) and hence may be assumed to contain a similar amount of uranium, about $0.5 \mathrm{ppb}$.

On the basis of the data and comparisons presented above, the waters of the Norwegian fjords are estimated to contain between 0.5 and $2 \mathrm{ppb}$ of uranium, the smaller value being more typical of the upper water, and the larger value typical of the saline water entering and occupying the zone of deeper water in the fjords.

Uranium is measured as only a fraction of one to a few parts per billion in sea water and a few tens to a few hundreds of parts per million in uraniferous mud and shale. The overall problem to be evaluated and solved is how this trace amount of uranium in sea water is withdrawn and concentrated in sediment to about 10,000 to 100,000 times the amount in sea water.

URANIUM CONTENT OF WATER IN ANCIENT SEAS

No method has been developed for measuring directly the amount of uranium that existed in the sea water in which ancient sediments were deposited. Consequently, interpretations of the uranium content of this water must be based on a general evaluation of changes in sea water composition in the geologic past, with particular reference to the measurable chemical and geologic characteristics of the sediments themselves.

One line of reasoning that has been used (for example, Breger and Deul, 1956, p. 508; Brown, 1956, p. 461-462) in attempting to explain differences in uranium content among marine sediments is that the amounts of uranium available for withdrawal from sea water differed at the times the different sedimentary units were deposited. Though not referred to in any previous reports, an example of this reasoning would be a comparison of the alum shale of southern Sweden, which contains 0.024 percent uranium, and the Chattanooga shale of the Southeastern United States, which contains 0.006 percent uranium; the inference would be that, other factors being equal, the Late Cambrian sea of Sweden contained four times more uranium than the Late Devonian sea of the United States.

The point of reference in attempting to determine the uranium content of ancient seas is the uranium content of modern sea water, here given as $3 \mathrm{ppb}$. The first question that might be asked is, did "average" sea water in the geologic past contain more than 3 ppb uranium? Holland and Kulp (1954, p. 204), in their analysis of the history of uranium and other radioactive elements from source to final deposition, concluded that the concentration of uranium in ocean water has not changed greatly since Paleozoic time. This conclusion is in line with those of Rubey (1951, p. 1114), Vinogradov (1953, p. 569), and Redfield $(1958$, p. 220$)$ who all believed that the overall composition of sea water has varied very little since early geologic time.

Koczy (1954, p. $121 ; 1956$, p. 98) thought that the uranium content of sea water may have varied in the geologic past because the chemical and biologic processes favoring uranium deposition in certain ocean areas probably changed considerably from one geologic period to the next; he $(1956$, p. 98$)$ speculated that the concentration of uranium in sea water may have varied by a factor of 3 . The objection to this interpretation is that the relative volumes of water that may have been wholly or partly depleted of their uranium were very small as compared to the total volume of sea water. Even if all the uranium was withdrawn from the water in a widespread epicontinental sea spanning most of a continent, the net loss of uranium in the total volume of the ocean would be insignificant. Add to this hypothesis the factor of time, because it presumably took millions of years for abnormally uraniferous sediments to accumulate, and 
the net change in uranium content of the ocean is seen to be probably negligible.

An argument that could be used to support the interpretation that ancient sea water probably contained more uranium than modern sea water is that, of the many marine shales that have been tested for uranium, the most uraniferous shales are of pre-Mesozoic age (Russell, 1945, p. 1486; Bell, 1954, p. 108; Nininger, 1954, p. 75; and others). The present author submits, however, that data are too few and too varied to permit a valid conclusion on the relation of geologic age to uranium content of black shale.

The results of the comprehensive geochemical study of more than 10,000 samples of the sedimentary rocks of the Russian platform, conducted by the Vernadskii Institute in Russia, show that the distribution of uranium is markedly uniform in clay and carbonate rocks of Cambrian to Recent age (Baranov, Ronov, and Kunashova, 1957, table 1). An objective of a chemical study on Precambrian sedimentary rocks of Canada $(1958$, p. 83$)$ was to determine if there are any variations in trace element content with age; on comparing the content of seven trace elements, including vanadium, nickel, copper, and manganese, in these rocks with published analyses of many younger marine argillaceous rocks, he concluded that no significant variations can be established in the amount of trace elements in sediments with relation to the age of the sediment. The explanation for the greater abundance of uraniferous shale in formations of pre-Mesozoic age more likely rests with specific circumstances of tectonics, rates of sediment deposition, chemical environments, and probably the proportions and types of organic material rather than with a hypothetical decrease of uranium content of sea water with younger geologic age.

From this very brief review, it can be seen that any statement made to the effect that "average" water in ancient seas contained more or less uranium than present sea water must be considered only as a speculation which at present is insupportable and unwarranted. It seems best to assume, therefore, that "average" sea water in the geologic past probably contained about the same amount of uranium as sea water today, $3 \mathrm{ppb}$.

A second question that should be considered is whether certain types or parts of seas might have contained more or less uranium than "average" sea water. An arm or embayment of an epicontinental sea theoretically could receive river water containing abnormally large amounts of uranium, and, because of partly restricted circulation with the open ocean, might have water of high uranium content. Seas with restricted circulation are favorable for black mud accumulation (Strøm, 1955, p. 366) and black mud rich in uranium might be expected to accumulate in this type of sea.

The Baltic Sea is a modern example of a partly restricted epicontinental sea having areas of black mud deposition, and uranium analyses of the water and mud data are available. Koczy, Tomic, and Hecht (1957, p. 88) reported analyses of the paters of 11 rivers entering the Baltic Sea; the waters of all rivers but one contain less than $1.5 \mathrm{ppb}$ uranium, and those of nine contain about $0.5 \mathrm{ppb}$ uranium. The average uranium content of the water in the Baltic probably is between 1 and $2 \mathrm{ppb}$, so this epicontinental sea and the water flowing into it actually contain less uranium than "average" sea water.

The uranium contents of other modern epicontinental seas wherein organically rich muds probably are being deposited, such as the Yellow Sea and Hudson Bay, are not known, so the validity of the concept of ancient seas with restricted circulation that contain more or less uranium than "average" sea water must be judged solely on the Baltic Sea data. Analyses of the waters of the Adriatic Sea (Karlik, 1939, p. 11) and of the Gulf of Mexico (Rona, Gilpatrick, and Jeffrey, 1956, p. 699) indicate that these bodies of water, which are largely surrounded by land but have well-circulated water, have about the same uranium content as the open ocean.

INFLUENCE OF SOURCE ROCK ON URANIUM CONTENT OF WATER IN BORDERING SEAS

The type of rock making up the drainage area of a marine basin of deposition has been considered to be of importance in determining the amount of uranium delivered to a sea and subsequently deposited in the marine muds and shales. As a result of a study of the uranium content of black muds in Norwegian fjords, Strøm (1948) concluded: "There seems to be a definite connection between drainage from granite areas and uranium content in the black muds, this being most conspicuous with the record value of $60 \mathrm{~g}$ per ton [0.0060 percent] in Topdalsfjord, into which empties a large river draining extended granite areas." Brown (1956, p. 461-462) suggested that the granitic landmass of Appalachia could have provided greater than average amounts of uranium to the sea in which the Chattanooga shale was deposited. Glebov (1941) considered the source of the uranium in the Dictyonema shales of Russia and Estonia to be the granite marginal to the sea in which these shales accumulated; and Joseph Eklund (cited in McKelvey, Everhart, and Garrels, 1955, p. 517) subscribed to a similar granitic-terrane theory for the source of uranium in 
the Cambrian alum shales of Sweden. McKelvey $(1955$, p. 15), in a list of distinguishing characteristics of uraniferous shales, included bordering granitic terranes.

Granitic terranes may well be the source of the sediments for the black muds and shales mentioned, but the implication that granitic terranes provided an abnormally large supply of uranium to the seas and that the subsequent concentration of uranium in the black muds is thus explained, is certainly open to question. The basis for the implied relation is that, of the common rock types, granite contains the highest average uranium content, 0.0004 percent (Holland and Kulp, 1954, p. 203).

The sequence of reasoning in the interpretation that the high uranium content of a shale is due to the relatively high uranium content of the granite which provided the sediment for this shale is apparently as follows: (a) If the uranium content of the black shale is high, the uranium content of the sea water in which the shale was deposited was high; (b) if the uranium content of the sea water was high, the uranium content of the streams emptying into the sea was high; (c) if the streams had a high uranium content, the rocks being eroded had a high uranium content; (d) of common rock types, granite has the highest average uranium content. In order to ascribe any validity to the interpretation that the uranium content of a shale is related to the uranium content of the source rock, each step in this sequence should be logical in itself and supported by some evidence.

The logic and evidence for relatively high uranium content in the water of ancient seas have already been shown to be highly dubious and implausible. From the thousands of analyses of surface waters, collected from all types of drainage areas in the United States, no relation between type of terrane and amount of uranium in the river waters has been noted (P. F. Fix, oral communication, 1957). Waters draining granite areas have no more uranium than the average of all stream waters (less than $1 \mathrm{ppb}$ ); because of the low permeability of most granites (and particularly if mechanical disintegration is the main weathering process), these waters actually may carry less uranium. The results of a study of the uranium contents of 12 rivers emptying into the Baltic Sea and Skagerrak (Koczy, Tomic, and Hecht, 1957, p. 86) show that the rivers draining areas of igneous rock have an average of $0.5 \mathrm{ppb}$ uranium, whereas rivers draining regions of sedimentary rock contain 2 or 3 times this amount. Hecht, Kupper, and Petrascheck (1958), in their study of creeks and rivers in Austria, reported similar observations.
If it were to be interpreted that eroded granite provided most of the sediment and the uranium in a black shale, it should not be assumed that all the granite's uranium was transplanted directly to the shale. It is known that upon weathering granite releases only a part of its total uranium to solution, because much of the uranium remains stable and fixed in highly resistant mineral grains such as zircon, sphene, and monazite. Most of these resistant grains are deposited in near-shore sandstones, with only a very small fraction reaching areas of black mud deposition. Most uraniferous shale contains less than 0.1 percent of these minerals, and the minerals in turn generally contain less than 0.1 percent uranium, so their contribution to the total uranium content of the uraniferous shale is almost negligible. Thus, nearly all the uranium in shale is that which was readily leached from granite and taken into solution.

The percent of the total uranium in granite that goes into solution upon weathering and that ultimately reaches the sea is not known, but laboratory studies by G. J. Neuerburg (oral communication, 1957) suggest that it is less, probably considerably less, than 50 percent. Pulverized samples of several granites from the United States yielded an average of about 20 percent of their total radioactive material when leached with dilute nitric acid (L. T. Silver and R. L. Kowalkowski, written communication, 1957); similar experiments on rhyolitic rocks from northern New Mexico resulted in leaching of only 1 to 13 percent of the uranium (R. S. Cannon, Jr., oral communication, 1957). On the other hand, data obtained by Larsen and others $(1956$, p. 67-68) and by Pliler and Adams (1959) indicate that about 60 percent of the uranium in granitic rocks is leached by acid solutions. Some loss of soluble uranium being inevitable between the place of granite erosion and the site of shale deposition, it is very doubtful that more than 25 percent of the total uranium in the granite is incorporated in the shale.

If an abnormally rich source of uranium is sought to explain the abnormally high uranium content of seas from which the black muds and shales drew their uranium, present information suggests that volcanic tuffs and other effusive rocks are the rock types that have a relatively high uranium content and that readily yield their uranium to surface and ground waters on weathering. In some areas these rocks contain an average of 0.0015 to 0.0035 percent uranium (Denson, Zeller, and Stephens, 1956, p. 680; Baranov, Ronov, and Kunashova, 1957, p. 3), and waters draining the area may contain several tens of parts per billion of 
uranium (Denson, Zeller, and Stephens, 1956, p. 673); if such waters drained into a sea, they might notably increase the uranium content of that sea.

The presence of a bentonite bed in the Chattanooga shale in Tennessee (Brown, 1956, p. 462) and of bentonite beds associated with the Sharon Springs member of the Pierre shale in Nebraska and South Dakota (Tourtelot, 1956, p. 78) has been cited as indicating the uranium content of the sea waters in which these beds were deposited was increased by volcanic ash falling directly into the waters. Whether volcanicash source rocks existed during times of black shale deposition or whether the volcanic ash that fell into black shale seas originally contained large amounts of uranium is unknown; these questions must be held as points of speculation at present.

From this evaluation, it is concluded that no evidence exists to support the oft-cited idea that granite, as a source of sediment, is also an abnormally rich source of uranium that can be dissolved and transported to the sea. On the other hand, studies on the stratigraphy and paleogeography of the cited black shales and muds indicate that these sedimentary rocks were derived from granitic rocks, and it follows that the uranium in them was also derived from the granite. The granitic rocks probably were not abnormally rich sources of soluble uranium; but, when viewed in proper perspective, they provide an ample supply for the uranium in the beds derived from them, including the black shales. Figure 23 illustrates a hypothetical and highly generalized, but nevertheless possible, arrangement of uranium distribution in the sediment derived from a granitic terrane. As visualized in this restored section of a body of rocks deposited during a limited period of time, the greater part of the uranium in the geosynclinal sedimentary beds is that originally retained in the resistant mineral grains, such as zircon and monazite, which were transported as suspended particles in the water. The major part of the uranium in the sediment deposited on the platform was derived from sea water by precipitation or sorption of the uranium in solution.

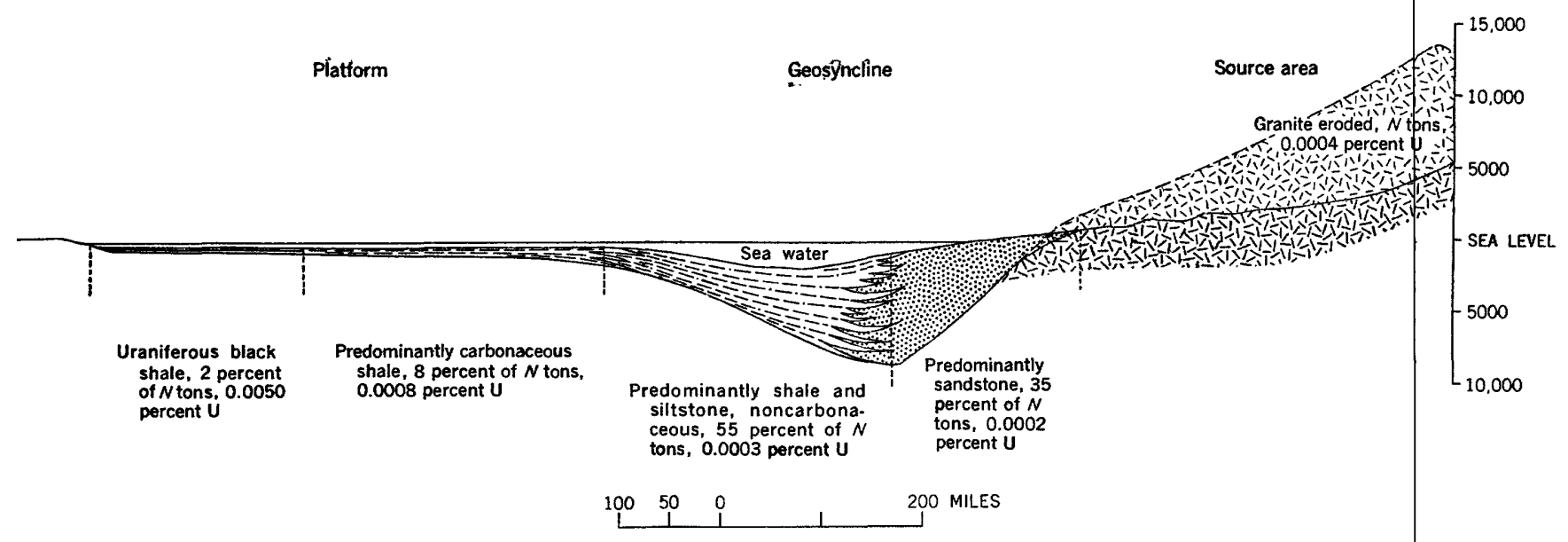

FiadrD 23.-Cross section showing hypothetical relation of volume (shown graphlcally) and weight ( $N$ tons) of granite removed from source area to volume and weight of sediment deposited; the uranium content of the original rock and the possible resulting balance in uranium content of the sediment are indicated. The average uranium contents shown are only approximate, based in part on data from Holland and Kulp (1954, table 3 ).

\section{SUMMARY OF URANTUM SOURCFS}

Sea water is recognized as the major source of uranium in marine black mud and shale. But the importance of differences in the uranium content of ancient sea water in determining the uranium content of black shale has received undue emphasis. No reliable evidence or interpretations can be cited to support the belief that ancient seas contained significantly more uranium than the $3 \mathrm{ppb}$ that modern seas have; nor can it be substantiated that eroded granite supplied abnormally large amounts of soluble uranium to seas, as maintained by some geologists to explain the high uranium content of some black shale and mud.

The emphasis on the concentration of uranium in ancient seas has been misplaced. Whether these seas contained 1 or $10 \mathrm{ppb}$, they still were extremely dilute solutions of uranium. Of far greater importance is the fact that, at either concentration, sea water was and is a vast and ample reservoir of uranium, and that sea water did and does serve as a highly effective medium for rapidly transporting and widely distributing uranium. 


\section{MECHANISMS OF FNRICHMENT}

ORGANIC MATTER

Organic matter, either directly or indirectly, is the most important constituent in the geochemical processes of concentrating uranium from sea water in black mud and shale. If uranium is present in abnormally large amounts in these deposits, the organic matter is directly or indirectly responsible; on the other hand, the presence of organic matter in either modern or ancient sediments does not indicate necessarily that uranium is present in large concentrations.

The shale and the modern sediments cited in table 1 all have more than 5 percent organic matter. The data on these deposits do not permit an estimation of the minimum amount of organic matter necessary to bring about a concentration of uranium; nor do they in themselves provide firm basis for postulation of a quantitative relation of organic matter to the abundance of uranium that would lead to a clear understanding of the genetic significance of organic matter. Neither does the available information quantitatively differentiate the kinds and types of organic matter present in the shale and mud. For these reasons, the relation of uranium to organic matter in these deposits necessarily must be generalized.

Ample evidence is available from the laboratory experiments cited in table 2 , however, to indicate that there can be a close and, in some cases, a direct tie between uranium and several kinds of organic matter.

AMOUNTS AND TYPES IN URANIUM-BEARING SHAIE AND MOD

Most of the organic matter in the Chattanooga shale is paleontologically unidentifiable; woody tissues of plants, now coalified (Breger and Schopf, 1955), and several types of spores and algae have been identified. The uppermost unit of the Chattanooga shale, which is used as the shale example in this discussion, contains 20 percent organic matter. Kinney and Schwartz $(1957$, p. 1125 , table 1) stated that this organic matter is similar to low-rank coals, the chemically separated organic matter having the composition on a percent-by-weight ash-free basis of :

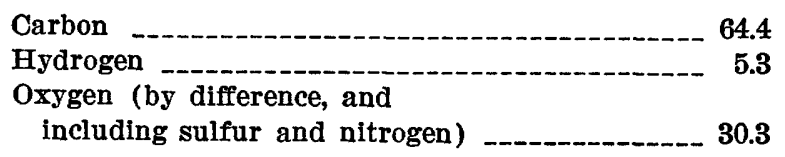

According to Deul (1957, p. 215-216), the organic matter in the Chattanooga shale has a composition close to that of a subbituminous coal; on a percentby-weight ash-free basis, calculated from analysis of the shale itself, it has this composition:

Carbon 78.3

Hydrogen 6.9
Sulfur

Nitrogen

2.9

Oxygen 2.3

One of the major conclusions from the studies of the Chattanooga shale at Pennsylvaina State University (Bates and Strahl, 1956, 1958; Bates and others, 1956 ) is that of all the constituents of the shale that were considered, such as carbon, pyrite, silicates, and numerous trace metals, only the carbon shows a constant, significantly positive coefficient of correlation (about 0.7) with the uranium. The genetic and precise chemical relations of the uranium to the organic matter, which this carbon represents, are not obvious from these studies.

Swanson (1960, p. 28) concluded that organic matter of the woody or humic type and the soluble organic substance derived therefrom are the mechanisms of concentration of a major fraction of the uranium in the Chattanooga shale. This conclusion was based on a study of the relation of the oil yield to the uranium content of the Chattanooga shale and on a comparison of the uranium contents of samples of identified algae (Foerstia sp.) and of coalified wood (Callixylon sp.), as determined by J. M. Schopf (written communication, 1953) and Breger and Schopf (1955). In this study by Swanson, two main types of organic matter were distinguished-the sapropelic type, derived from algae, spores, pollens, resins, cuticles, and chemically analogous plant and animal remains; and the humic type, derived from cellulose, lignin, and analogous woody parts of plants. Both types are present in most black shale. The sapropelic type of organic matter yields 4 to 5 times more oil on distillation than does the humic, whereas the humic type contains, or indirectly induces the precipitation of, most of the uranium in black shale.

The amounts of organic matter in the samples of the Norwegian fjord muds that were analyzed for uranium (Strøm, 1948) are not known; however, the total organic matter in these samples is probably between 10 and 40 percent by dry weight, based on analyses of "black, flocculent" muds from 8 fjords cited by Strøm (1936, p. 61-62). Wood fibers, saw dust, pine pollen, and fragments of sphagnum moss are the types of plant material in the black mud accumulating in the Norwegian fjords (Strom, 1936, p. 60-65). The amounts of each type in the samples are not given, but woody material, or the humic type of organic matter, is certainly present; and, as suggested by the abundance of the decay product hydrogen sulfide, the relatively low $\mathrm{pH}$, and the reducing conditions in the overlying waters, the humic type of organic matter probably predominates. 
The amounts and types of organic matter in the Baltic Sea samples described by Koczy, Tomic, and Hecht (1957) are not known, but these authors concluded (p. 86) that the uranium is complexed by the organic materials in the water to form insoluble compounds which settle to the bottom. Samples of mud collected in 1930 (Gripenberg, 1934, p. 119; 1955) from the Gotland deep, only a few miles from the place where the most uraniferous sediment reported by Koczy, Tomic, and Hecht (1957, table 3) was collected, contain the most organic matter (6.7 to 9.9 percent of the dry mud) of any of the samples from more than 60 stations in the Baltic. Most of the modern muds in the Baltic contain organic matter in the 3 to 4 percent range (Gripenberg, 1934, p. 137). Gripenberg (1934, p. 22, 144, 159) repeatedly stated that the organic matter in the Baltic sediments is largely "land humus," or plant material of terrestrial origin; she further described most of this organic matter as colloidal and as having been precipitated from the sea water to form a gelatinous-appearing black mud (p. 164-165, 217). Segerstråle (1957, p. 766) described the abundant "humus compounds" transported into the northern Baltic Sea from the large peat bog districts, mainly in Finland, which in places give the sea a brown color. These general descriptions suggest that humic substances, possibly flocculated humic acids in part, may form some of the organic matter in the Baltic Sea sediments; but the types of organic matter and the relations of each to uranium in the Baltic Sea muds are still to be investigated.

The applicability of any of the cited experimental results (table 2) in defining the relation of the organic matter to the uranium in the modern black muds or in the shales must await the careful separation and the accurate identification and classification of the types of organic matter, with uranium determinations made on each type. Any discussion of the possible relation of uranium to types of organic matter in sediments, as indicated by the experiments, therefore must be considered at present as largely subjective and interpretative.

\section{SOLID ORGANTC MATTER}

The fact that uranium can be sorbed from a uranium solution and irreversibly fixed by solid organic matter, particularly wood, peat, and coal, has been demonstrated many times in the laboratory (for example, Moore, 1954; Szalay, 1954; Rozhkova and others, 1958; see also table 2). Natural concentrations of uranium in decaying plant substances from surface water having a high uranium content have been recorded from alpine meadows (Swanson and Vine,
1958). The manner of chemical combination of organic matter and uranium is not known, but probably is by ion exchange or formation of a metalorganic compound. Fragments of coalified drift wood, Callixylon, in the Chattanooga shale are the most uraniferous constituents (with as much as 0.035 percent uranium) of this rock. On the basis of this experimental and geologic evidence, it is suspected that some of the woody fibers and sawdust particles in the fjord mud contain more uranium than the sediment as a whole and may account for a significant fraction of the uranium in this mud.

\section{HUMIC ACIDS}

The soluble organic substances that are extracted by slightly alkaline waters from decaying humic plant matter such as peat generally are referred to as humic acids. These colloidal or soluble humic substances constitute most of the organic matter in the water of many lakes (Hutchinson, 1957, p. 901-902), and, though not so well studied, at least some of the organic matter in marine sediments (Waksman, 1936, p. 295301). For example, Waksman (1933, p. 136), using a dilute alkaline solution, extracted 70 percent of the total organic matter from a sample of marine mud from Buzzards Bay, in southeastern Massachusetts.

Humic acids have been shown experimentally to be effective in withdrawing and firmly attaching uranium from solution (Szalay, 1954; Manskaya, Drozdova, and Emeliyanova, 1956); Szalay (1958) concluded that the process is one of ion exchange, where uranium ions displace the hydrogen ions of the organic substance. The uranium-bearing humic acids are flocculated as a dark-brown gel when the $\mathrm{pH}$ of the solution is lowered to the acid side or when divalent cations such as calcium are added. These flocculated humic acids may contain several percent uranium, dry weight (Szalay, 1954 and 1958), and their counterpart in nature may account for a large part of the uranium in some black mud and shale deposits (Beers, 1945, p. 15; Vine, Swanson, and Bell, 1958, p. 190). The importance of this mechanism of uranium concentration could easily be demonstrated by extracting the alkaline-soluble organic substance, or humic acids, from modern uraniferous black mud such as that in the Norwegian fjords, then recoagulating, drying, and determining the uranium content of this substance.

The dark-brown to black structureless material which constitutes much of the organic matter in marine black shale, as seen in thin sections, may be flocculated humic acids or their salts, which are here termed "humates." Just as in coals, these solidified humic acids or humates have lost their initial solu- 
bility characteristics during diagenesis, and they can be dissolved in dilute alkaline solutions and extracted only after being partially oxidized; the humic acids dissolved and extracted from shale in this manner have a composition and structure which are probably very similar to the original material. The studies on the Chattanooga shale by Kinney and Schwartz (1957, table 2) show that more than 50 percent of the carbon in the shale is in the "regenerated" humic acids extracted from the partially oxidized shale. The ashfree composition of these humic acids from the Chattanooga shale and of the humic acids similarly derived from coal are very much alike, as shown by the analyses below from Kinney and Schwartz (1957, table 6) :

\begin{tabular}{|c|c|c|}
\hline & $\begin{array}{l}\text { Humic acids, } \\
\text { Chattanooga shale } \\
\text { (percent) }\end{array}$ & $\begin{array}{l}\text { Humic actds, } \\
\text { Pittsburgh coal } \\
\text { (percent) }\end{array}$ \\
\hline Carbon & 64.1 & 65. 6 \\
\hline Hydrogen & 2. 5 & 2. 3 \\
\hline Sulfur & 2. 8 & 1. 0 \\
\hline Nitrogen & 2. 2 & 1. 4 \\
\hline Oxygen & 28. 4 & 29. 7 \\
\hline
\end{tabular}

The humic acids extracted from the Chattanooga shale retain a part of the uranium initially in the shale (Kinney and Schwartz, 1957, p. 1126), but their original uranium content is not known; when the abundant pyrite of the shale is oxidized and the soluble products are freed, sulfuric acid forms and undoubtedly takes much of the uranium into ionic solution. It has been suggested (Swanson, 1960, p. 24) that the scattered lenses of kolm in the Upper Cambrian alum shale of Sweden are humates because of their high uranium content ( 0.1 to 0.7 percent), their relatively low oil yield (a few percent), and their similar appearance to natural and artificial humates.

Dissolved organic matter in marine waters may be derived from two major sources. The first is the plant and animal life within the sea itself, mainly planktonic organisms such as algae and Protozoa but also other planktonic invertebrates. Scavengers or processes of aerobic decomposition eliminate the carbohydrates, proteins, and fatty acids that make up the larger part of the dead organisms, but some humic acids may form during decomposition, particularly from some algae. Humic acids are generally resistant to additional bacterial and chemical attack and are eventually precipitated, deposited, and incorporated as organic matter in the bottom sediment.

The second source is the decomposing plant material on land. The humic acids in shallow continental seas derived from decomposed land plants may be quantitatively more significant than the humic acids from organisms living in the sea, especially in tropical and subtropical climates. The land-derived humic acids are flushed from peat and soil and are transported by streams into the sea in a colloidal state, where they ultimately are precipitated and deposited. Waksman (1933, p. 135) stated that commonly 70 to 75 percent of the total organic matter in soil can be removed by dilute alkaline solutions. Clarke (1924, p. 110) reported that the percent of organic matter in the dissolved solids of 18 rivers in the world ranges from 3.25 to 59.90 percent and averages about 20 percent. Using Clarke's data, Corbett (1955, p. 1609) estimated that more than 100 million tons of soluble organic matter, or humic acid, is brought to the sea every year.

Gripenberg (1934, p. 163-164, table 22) estimated the amounts of dissolved "humus stuffs" transported annually by rivers into the Baltic Sea and presumably deposited there (fig. 24). She estimated that the mean organic content of river water, exclusive of suspended organic matter, entering the Baltic is 30 grams per cubic meter of water, and the mean annual addition to the bottom sediment of the Baltic, if this material is precipitated and preserved, is 19 grams per square

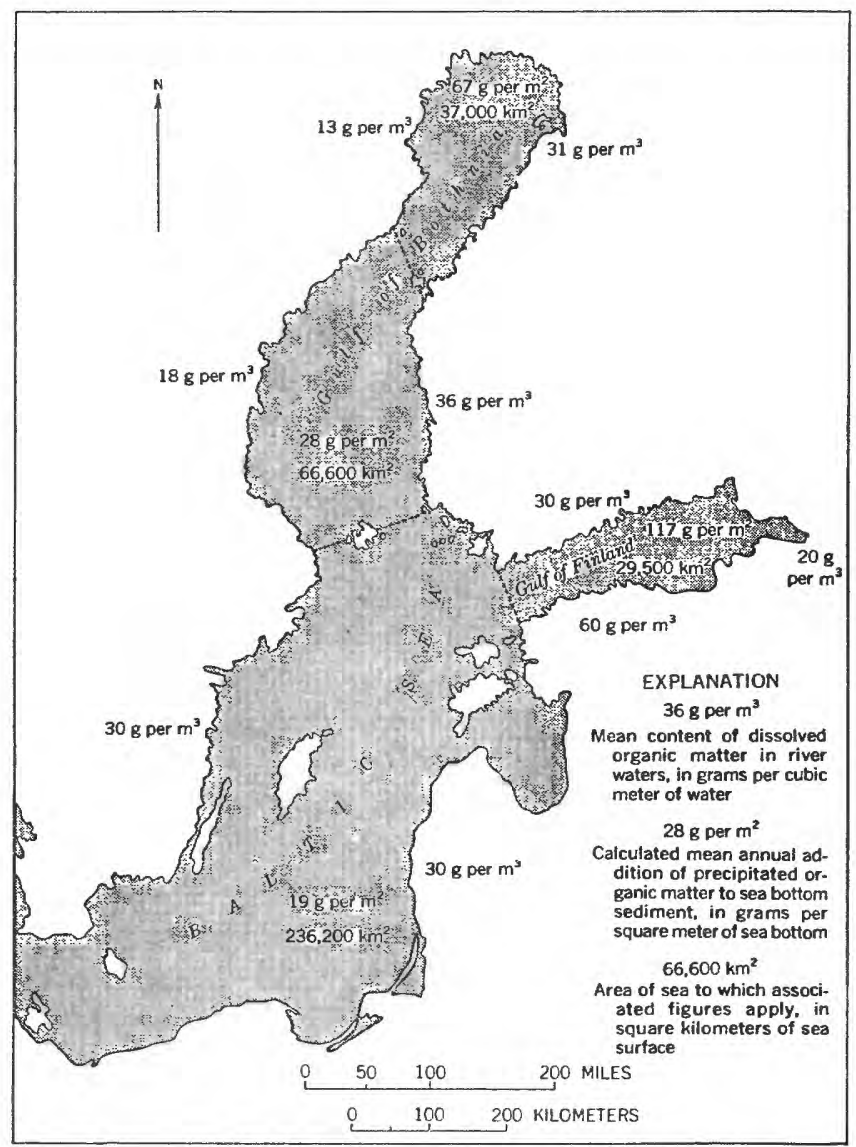

FIGUR 24.-Map indicating the amounts of dissolved organic matter in the river water entering the Baltic Sea area, and the estimated amounts precipitated and deposited annually with the bottom sediment. Data from Gripenberg (1934, table 22). 
meter. Evaluation of all the data for the entire Baltic Sea area, including the Gulf of Finland and the Gulf of Bothnia, gives the estimated mean annual addition of precipitated humates of about 33 grams per square meter. (For purposes of comparison, Emery and Rittenberg, 1952 , p. 776 , estimated that between 31 and $52 \mathrm{~g}$ of total organic matter per $\mathrm{sq} \mathrm{m}$ reach the bottom water of the basins off southern California; see also Trask, 1955). The actual amount of humates in the bottom sediment obviously is dependent on the distribution of these humic acids, on the rates of their biologic and chemical destruction, and on the local rates of deposition of clastic sediment; but, at least theoretically, humic material makes up much of the organic matter accumulating on the bottom of large parts of the Baltic Sea area.

A logical criticism of the thesis that a large part of the organic substances in marine sediment was once in solutions derived from land is that the distribution of this material would be limited and would be localized near the land. When humic acids in fresh water enter the sea, a part may be precipitated as humates by such cations as calcium, magnesium, or aluminum, though this manner of precipitation has been questioned by Alekin and Moricheva (1958). Some of the precipitated humates may be concentrated near the mouths of rivers, but much of the humic acids will be carried far out to sea by the fresh water that remains at the surface and causes the water to be stratified over large areas (Schuchert, 1915, p. 266). The lighter fresh water becomes mixed with the lower saline water only when they are intermittently circulated by storms, or when an inversion takes place due to the cooling of the surface water by seasonal changes in atmospheric temperatures.

When the humic acids are precipitated or flocculated they may be widely dispersed before they are deposited. In still water, the flocculated humates settle to the bottom very slowly as small, filmy, gelatinous particles; minor agitations or currents tend to keep them in suspension, and an even wider distribution results.

If the origin, the large amount, and the wide distribution of humic acids in shallow seas are accepted as likely, and if this material does adsorb or complex uranium with which it comes into contact, humic acids may be an important mechanism for implanting uranium within marine black shale. The retention of some uranium by the humic acids chemically extracted from the Chattanooga shale, and the similarities between the highly uraniferous Swedish kolm and humates are strongly suggestive evidence for this postulated mechanism of uranium concentration in shale.

URANIUM INCORPORATED BY IIVING PLANTS AND ANIMAIS

One possible relation between organic matter and uranium not indicated in table 1 is that the uranium may have been extracted from sea water and incorporated by living plants and animals. The meager data on the uranium content of living marine organisms do not lend support to this possible origin of the uranium in black shales.

D. R. Norton (written communication, 1955) found that plankton in six bulk samples collected from 17 to 27 meters below the surface of the northwestern Atlantic Ocean contain 0.08, 0.66, 4.8, 1.5, 1.7, and $0.99 \mathrm{ppm}$ of uranium in the dried material, whose water-soluble salts had been removed. Norton also recorded the uranium content of a dried, washed sample of the alga Sargassum as being only $0.6 \mathrm{ppm}$, or 0.00006 percent. A. P. Pierce (written communication, 1958) reported that marine algae from off the coast of Japan contained uranium in the ash, as follows: Porphyra sp. (purple alga), $1.7 \mathrm{ppm}$; Laminaria sp. (calcareous alga), $0.8 \mathrm{ppm}$; and Undaria sp. (brown alga), $3.0 \mathrm{ppm}$. As indicated by these data, most of the marine plankton settling to the bottom of a sea probably contains only 1 to $2 \mathrm{ppm}$ uranium ( 0.0001 to 0.0002 percent), or only $5 \mathrm{ppm}$ at the most.

It might be argued that after the death and decomposition of these organisms as they settled to the bottom, the percent of uranium would be greater in the remaining organic residue which is deposited. It is believed, however, that this deposited residue generally would contain $10 \mathrm{ppm}$ or less uranium, which is still far too low to explain the several tens of parts per million in the gross shale and mud samples cited in table 1. This decomposing organic substance might sorb additional uranium from sea water during the time taken to settle to the bottom of the sea; Koczy, Tomic, and Hecht (1957, p. 86, 98-99) suggested this mechanism of uranium withdrawal to explain the lower uranium content of the upper water of the Baltic Sea.

Two samples of the Devonian alga, Foerstia sp., one from the Ohio shale (J.M. Schopf, written communication, 1953) and the other collected from the New Albany shale in Indiana by R. C. Robeck, contained 0.0016 and 0.003 percent uranium, respectively. These uranium contents are much higher than that of modern marine algae or plankton, but the difference may be explained either by the contamination of the sample with other black shale material as indicated by 55.8 percent ash in the sample from the Ohio 
shale or by sorption of uranium by the algal matter after death, rather than by an originally high content of uranium in the living plant. Two samples, collected by the author, of what appeared to be the carbonized remains of fish from the Chattanooga shale contained 0.002 and 0.003 percent uranium, but this amount of uranium probably is also best explained by either contamination or sorption after death of the animal. It might also be mentioned here that uranium content of fish bones, linguloid brachiopod shells, and conodonts, which are all phosphatic fossils present in the Chattanooga shale, is less than 0.005 percent; inasmuch as these fossils make up less than 1 percent of the rock, their contribution to the total uranium in the shale is insignificant. This limited evidence suggests, therefore, that uranium now found in black mud and shale was not concentrated by the living marine organisms before they died and were buried in these sediments.

\section{HYDROGEN SULFIDE}

PRECIPITATION OF URANIUM BY HYDROGEN SULFIDE

Hydrogen sulfide is generated when sulfur-bearing organic substance is decomposed by anaerobic bacteria. It is also formed when marine anaerobic bacteria attack the sulfate present in water to obtain the oxygen in the sulfate ion for their metabolic processes. $\mathbf{H y}$ drogen sulfide dissolved in water increases the reducing capacity of the water and tends to make the water slightly acid, and it may react with metallic ions to form sulfide minerals, or when circulated with oxygenated waters it may be reoxidized to form sulfate ions.

The hydrogen sulfide produced in the black mud environment may be critical in the precipitation of uranium in and on organic-rich sediment. The precipitation of uranium from solution by hydrogen sulfide was accomplished in the laboratory more than a century ago (Kessler, 1857), and hydrogen sulfide has been cited as a probable mechanism causing the precipitation of some of the primary uranium ores in sandstones of the Colorado Plateau region of the United States (Gruner, 1952; Jensen, 1958).

Strom (1948) suggested that the uranium in the muds of the Norwegian fjords was precipitated as the upper ventilated brackish water came into contact with the lower salt water containing hydrogen sulfide. Goldschmidt (1954, p. 566), McKelvey, Everhart, and Garrels (1955, p. 518), and Breger and Deul (1956, p. 507) also suggested that uranium precipitated by hydrogen sulfide may be the explanation for some or most of the uranium in black shale.

The effectiveness of hydrogen sulfide as a reducing agent capable of precipitating uranium from solu- tions in the laboratory is well established (table 2). However, no experiments (for example, using large amounts of water containing $5 \mathrm{ppb}$ uranium, and 10 to $200 \mathrm{cu} \mathrm{cm}$ of $\mathrm{H}_{2} \mathrm{~S}$ per liter of water) have been conducted to determine if uranium can be precipitated and concentrated by hydrogen sulfide within the range of values present in natural marine environments. Carroll $(1958$, p. 12,20$)$ showed experimentally that introduction of $40 \mathrm{cu} \mathrm{cm}$ of hydrogen sulfide per liter to sea water caused the $\mathrm{pH}$ to drop from 7.95 to 7.0 and the water to change from an oxidizing medium to a reducing one with a drop in Eh from +0.380 to -0.025 . Rafalsky $(1958$, p. 439$)$ showed by a series of experiments, mainly at elevated temperatures and with rich uranium solutions, that even where hydrogen sulfide is present in highly dilute concentrations the reduction and precipitation of uranium still takes place. Finally, Miller (1958) showed that the complex uranyl ions which probably are present in natural water will react with hydrogen sulfide, at $\mathrm{pH}$, temperature, pressure, and uranium-concentration ranges comparable to those that exist in nature, to precipitate very small crystallites of pitchblende.

The mechanism of uranium precipitation and concentration from sea water by the action of hydrogen sulfide certainly is indicated as an important one, on the basis of the abundance of pyrite in the uraniferous shales, the abnormal amounts of hydrogen sulfide in waters of some of the Norwegian fjords, and the highly suggestive experimental evidence.

\section{URANIUM PRECIPITATED BY HYDROGEN SULFIDE IN CHATTANOOGA SHALE}

In a shale such as the Chattanooga, the presence of hydrogen sulfide at some stage in the history of the sediment is indicated by the presence of sulfide minerals. The most common sulfide mineral is pyrite $\left(\mathrm{FeS}_{2}\right)$; there is some marcasite $\left(\mathrm{FeS}_{2}\right)$, and, though rare, minute crystals of galena $(\mathrm{PbS})$ also have been observed. The genesis of pyrite in sedimentary rocks will not be reviewed here (see Galliher, 1933; Yoshimura and Wada, 1938; Emery and Rittenberg, 1952; Debyser, 1957; Huber, 1958), but there is no reason to doubt that shale containing 7 to 22 percent by weight of pyrite (or 3 to 10 percent pyrite sulfur) strongly indicates mud in which abundant hydrogen sulfide was produced and trapped.

Studies of the Chattanooga shale at Pennsylvania State University (Bates and others, 1956, p. 62-63) show a positive, but not significant, coefficient of correlation (about 0.4 ) between the amounts of pyrite and uranium, but the pyrite and uranium are not chemically combined (Bates and Strahl, 1957, p. 1310). An even higher coefficient of correlation (about 
$0.65)$ is shown between the amount of uranium and the amount of carbon and pyrite combined; Bates and Strahl interpreted this correlation to mean that the environment conducive to carbon accumulation is also conducive to the growth of pyrite and the precipitation of uranium.

A similar conclusion was reached by C. R. Kinney and others (written communication, 1958), another group at Pennsylvania State University that attempted to determine the exact chemical associations between uranium and the organic matter in the Chattanooga shale. After many experiments designed to isolate and fractionate the organic matter and after subsequent analysis of the fractions, their results indicate "that the uranium is deposited more or less evenly throughout the shale $* * *$. Although uranium is probably deposited in the shale because of the presence of organic matter, it is not associated with either the mineral matter or the organic matter exclusively." This conclusion is compatible with and supports the interpretation that the organic matter was responsible for the production of hydrogen sulfide, which in turn precipitated the available uranium.

Deul $(1955$; 1957) subjected samples of Chattanooga shale to several kinds of mechanical separation procedures and found that uranium was not concentrated in either a dominantly mineral or organic-matter fraction, but was concentrated in a colloidal-size fraction which contained as much as 0.08 percent uranium. Insufficient material of this colloidal phase existed to determine the chemical form or associations of the uranium, but Deul (1957, p. 218) concluded that the uranium was not combined with the organic matter but was derived from sea water by reduction of the uranyl ion to uranium dioxide.

A few logical questions should be considered. Why is there always such a close correlation between uranium and organic matter in the Chattanooga shale? If uranium was precipitated as a solid, why are minerals of uranium oxide not identifiable and separable from the shale? Because hydrogen sulfide may be a direct product of decomposition of organic matter, any uranium precipitated from overlying water by the rising hydrogen sulfide probably would fall on or very near the organic matter. Further, uranium so precipitated from a solution as dilute in uranium as sea water probably would be in the form of ultramicroscopic, but relatively heavy (sp gr 8 to 10), particles disseminated on and through the organic sediment, which results in an admixture that with existing methods is largely physically inseparable. It is also possible that the uranium so precipitated became physically or chemically bound in some way to adjacent particles in the sediment during diagenesis and that it no longer exists as discrete identifiable uraninite particles.

\section{RELATION OF PYRITE TO URANIUM}

The significance so far given to the iron sulfide minerals, particularly pyrite, in either black mud or black shale is that they are positive evidence of the former existence of hydrogen sulfide in these sediments. Most, if not all the iron sulfide minerals are formed by combination of hydrogen sulfide and ferrous ions within bottom water or within bottom sediment and are deposited as a syngenetic, or penesyngenetic, amorphous substance with the black mud.

Two general hypothetical circumstances should be considered as to the relations among hydrogen sulfide, pyrite, and uranium in the black mud environment: whether the hydrogen sulfide is confined within the sediment, or whether the hydrogen sulfide rises from the sediment into the overlying water. In the first circumstance, oxidizing or only very slightly reducing conditions, with little or no hydrogen sulfide, generally exist in the uppermost few inches of sediment (Zobell and Feltham, 1942; Emery and Rittenberg, 1952, p. 773 ; Harvey, 1955, p. 150), and oxygen is present and hydrogen sulfide absent in the immediately overlying water. In this case, iron sulfide minerals form below the oxidizing zone, and any reduction and precipitation of uranium by hydrogen sulfide must be from water within the sediment. This interstitial water probably contains no more uranium than sea water, and because the volume of this water is very small in comparison to the mass of overlying sea water, the concentration of uranium by hydrogen sulfide is negligible. These conditions undoubtedly obtain in the Baltic Sea muds, and they may in part explain the rather small amounts of uranium in these sediments. Debyser (1957, fig. 3) showed that the pyrite in the Recent organic-rich muds from many parts of the Baltic generally forms 20 to $250 \mathrm{~cm}$ below the surface of deposition.

In the second circumstance, where the hydrogen sulfide rises from the sediment into the overlying water, the reduction and precipitation of uranium from the water could proceed readily until the uranium from the hydrogen-sulfide-charged water is exhausted. Iron sulfide minerals, of course, would form in and on the mud in this example.

It should be obvious that the formation of abundant pyrite does not indicate necessarily that conditions favoring the precipitation and concentration of uranium existed simultaneously. The absence or small amount of uranium in many pyritiferous black 
and gray shales suggests either that the hydrogen sulfide was confined within the sediment or that uranium was not available in the overlying water. On the other hand, it seems reasonable that shale with abundant pyrite and more than 0.001 percent syngenetic uranium probably formed where hydrogen sulfide was diffused upward from the decomposing organic sediment into the overlying water.

An explanation similar to that of the pyrite-uranium relation probably applies to a large suite of metals commonly concentrated in a black mud environment-lead, zinc, copper, molybdenum, cobalt, and probably other elements. For example, Korolev (1958, p. 461) showed experimentally, using hydrogen sulfide, that 70 to 96 percent of the molybdenum is coprecipitated with iron sulfide from solutions whose compositions resemble natural ones in their $\mathrm{pH}$ and salinity.

BOTTOM WATER OF NORWEGTAN FJORDS AND BATITO SEA

As graphically shown by Strøm (1936) and indicated in table 3, hydrogen sulfide is present in the stagnant bottom water of many of the fjords. The amount of free oxygen in the water gradually decreases with depth until oxygen is absent; at about this zero-oxygen depth, traces of hydrogen sulfide are recorded, and the amount of hydrogen sulfide in the water than increases with greater depth to the bottom of the fjords. The maximum amount of hydrogen sulfide is $199.5 \mathrm{cu} \mathrm{cm}$ per liter of water, with amounts in the range 1 to $10 \mathrm{cu} \mathrm{cm}$ per liter being the most common. The zone of water containing hydrogen sulfide in the Framvaren fjord in 1933 was about 450 feet thick. Uranium is very likely precipitated within this hydrogen sulfide zone and falls on the bottom black mud.

The importance of precipitation of uranium by hydrogen sulfide is difficult to evaluate, but its possible importance can be suggested on the basis of the data in table 3. Some of the fjord muds contain much more uranium than do the Baltic Sea muds, and one of the obvious differences between the two areas is that the bottom waters of the fjords are characterized by hydrogen sulfide whereas most of the bottom water of the Baltic is oxygenated. No positive correlation is apparent between uranium content of the sediment samples and amount of hydrogen sulfide in the bottom waters of the fjords, but it is considered very possible that such a relation could be shown if other factors were evaluated.

If it is assumed that sedimentation in a fjord is uniform and continuous and that the lower waters are stagnated, the available uranium in the mass of water invaded by hydrogen sulfide is seen to be a finite amount. Once the hydrogen sulfide and oxygen boundary reaches a static upper level and the water below this boundary is depleted of its uranium by hydrogen sulfide precipitation, continued stagnation for long periods of time will not result in the addition of uranium to the sediment. It is thus conceivable that the mud containing abundant organic matter which is deposited late during a period of bottomwater stagnation might have little or no uranium, though this mud may be contiguous with and otherwise physically identical with the underlying uraniferous mud. This latter condition might serve to explain the variable correlation coefficient of uranium to organic matter, to carbon (for example, Bates and others, 1936 , p. 54-57), or, for that matter, to any other constituent in black shale.

Black mud from the Indre Topdalsfjord contains the most uranium (table 3), but hydrogen sulfide in the bottom water was barely detectable. This example does not negate a possible genetic relation of uranium to hydrogen sulfide, but rather may be used to verify the relation and to shed light on the importance of the availability of uranium in the water. From information given by $\operatorname{Str} \not m$ (1936, p. 50, fig. 36) the bottom water of Indre Topdalsfjord is ventilated and partly flushed out by oxygenated sea water almost yearly, and the process of stagnation and of formation of hydrogen sulfide sets in immediately after this renewal of water. A hydrogen sulfide zone did exist in the bottom water of this fjord through 1926 and early 1927, in early 1932, in early 1933, and probably in 1935; the measurement by Strøm (1948) in 1947 presumably was made either at the beginning or end of another period of bottom-water stagnation. This periodic or intermittent influx of saline water might explain a replenishment of uranium which could be precipitated to result in exceptionally uraniferous mud.

The two fjords that had the most hydrogen sulfide in their bottom waters are Framvaren $(199.5 \mathrm{cu} \mathrm{cm}$ per liter) and Hellefjord (40.7 cu cm per liter). Strom (1936, p. 46) stated that "there is reason to believe that the [Framvaren] bottom waters have not been ventilated for a very long time." The observed renewals of water in the 1850 's and in 1905 indicate that Hellefjord "is only ventilated at intervals of some 50 years" (p. 57). Except for Vestrhusfjord, which was ventilated in 1923 and 1933 (p. 54), no additional information is given on the times of water ventilation of the fjords for which uranium data on sediment samples are available. It is postulated here that the water containing uranium in solution, small 
as the uranium content of this water may be, must be renewed continually or periodically to deposit muds having a high uranium content. In the case of Framvaren and Hellefjord, access to more uranium-bearing waters could be attained only if the upper boundary of the hydrogen-sulfide zone rises; this rise apparently had been terminated when the two fjords were studied in 1933, as the upper limits of hydrogen sulfide in both were at depths of 50 to 65 feet, the approximate maximum depths of surface-water disturbance (Str $\phi \mathrm{m}, 1936$, p. 58).

In the Baltic Sea the amount of hydrogen sulfide, the periodicity of its expulsion from the sediment into the overlying water, and the volume of bottom water affected by hydrogen sulfide are unknown. In 1931, Granquist (1932, p. 24) recorded hydrogen sulfide in the bottom water at only 1 of more than 70 stations occupied in the Baltic that year; in 1932, he (1933a, p. 12) noted only that no oxygen was present in the lower water at the same station; and in 1933 (1933b, p. 12), he recorded $1.40 \mathrm{cu} \mathrm{cm}$ of oxygen per liter. Gripenberg $(1934$, p. 128) showed that the bottom water at this same station was slightly oxygenated in 1926 and 1930. This station, No. F81 (lat $57^{\circ} 22^{\prime} \mathrm{N}$.; long $19^{\circ} 57^{\prime}$ E.), was in the Gotland deep, very near locality 6 (lat $57^{\circ} 20^{\prime} \quad \mathrm{N}$.; long $19^{\circ} 54^{\prime}$ E.) of Koczy, Tomic, and Hecht (1957), which in 1953 had $1.43 \mathrm{cu} \mathrm{cm}$ of oxygen per liter in its bottom water. As recorded in table 3, one of the samples of sediment collected at the latter locality contained the most uranium, 0.00103 percent, of any of the Baltic Sea samples. It should also be noted that in 1931 the bottom water (200-220 meters deep) of station F81, as reported by Granquist, had a $\mathrm{pH}$ of 6.94 to 7.09 and contained " $>200$ " mg $\mathrm{P}_{2} \mathrm{O}_{5}$ per cu m, minimum $\mathrm{pH}$ and maximum $\mathrm{P}_{2} \mathrm{O}_{5}$ values for all the Baltic stations; thus, the presence of hydrogen sulfide, the $\mathrm{pH}$, and the amount of phosphate make this Baltic water comparable, at least occasionally, to the bottom waters of some of the Norwegian fjords. The fact that the Baltic mud contains considerably less uranium and, as indicated by Granquist's data, that the bottom water of the Baltic is rarely charged with hydrogen sulfide, does lend support to the postulated genetic and geochemical relation of the uranium and the hydrogen sulfide.

POSSIBLE EXTRAPOLATIONS AND INTERPRETATIONS

From the preceding discussion, which has touched on only some of the more obvious relations of hydrogen sulfide, pyrite, and uranium in the deposition of organic-rich mud, the interdependency of several factors that might affect concentration of uranium by hydrogen sulfide in black marine muds can be interpreted and summarized.

Hydrogen sulfide generated from decomposing organic matter in the bottom muds of some fjords rises into and accumulates in large amounts (generally about $10 \mathrm{cu} \mathrm{cm}$ per liter, but as much as $199.5 \mathrm{cu} \mathrm{cm}$ per liter) in the overlying water. This hydrogen sulfide acts as a reducing agent, and the uranium in the water probably is precipitated as colloidal-size uranium oxide which falls onto the bottom sediment.

Iron sulfide minerals, common to and abundant in many black shales and muds, clearly indicate the presence of a hydrogen sulfide environment in which uranium could have been precipitated at the time the sediment was deposited. A positive correlation between the amounts of iron sulfide and of uranium might thus be expected, but in actuality such a quantitative relation would be fortuitous only. If it is assumed that the formation of abundant iron sulfide minerals in the sediment is at a constant rate, the amount of uranium precipitated by hydrogen sulfide can be shown to differ radically, depending on whether the hydrogen sulfide is confined below the sedimentwater interface or is diffused into the overlying water; if the latter circumstance were existent, the amount of precipitated uranium would vary with the uranium content of the overlying water and the volume of the water column invaded by hydrogen sulfide.

The amount of uranium that can be precipitated by hydrogen sulfide is limited to the amount of uranium in the water reached by hydrogen sulfide. Estimates can be made of the mass of water that would have to be charged with hydrogen sulfide to explain the uranium in the bottom muds of the Norwegian fjords. As indicated in figure 25, the bottom waters of the fjords would have to be renewed several times in a 10-year period to explain the uranium in the bottom muds.

For example, if the bottom sediment of fjord $X$ contains 0.0060 percent uranium ( $a$, fig. 25) and the uranium content due to precipitation by hydrogen sulfide is 0.0050 percent $(b)$; if the fjord water is 100 $\mathrm{m}$ deep, and the lower $50 \mathrm{~m}$ of water intermittently becomes stagnant, charged with hydrogen sulfide, and depleted of all its uranium by precipitation; if the original renewing water contains $2 \mathrm{ppb}$ of uranium $(c)$; and if the rate of accumulation of the bottom mud is $1 \mathrm{~cm}$ every 10 years $(d)$ (approximated from data on Drammensfjord sediment, Str $\not \mathrm{m}, 1936$, p. 65 and 68 ), and the weight of the partially compacted mud is $100 \mathrm{lb}$ per cu ft or about $1,600 \mathrm{~kg}$ per cu m; then this bottom water would have to be replaced 8 


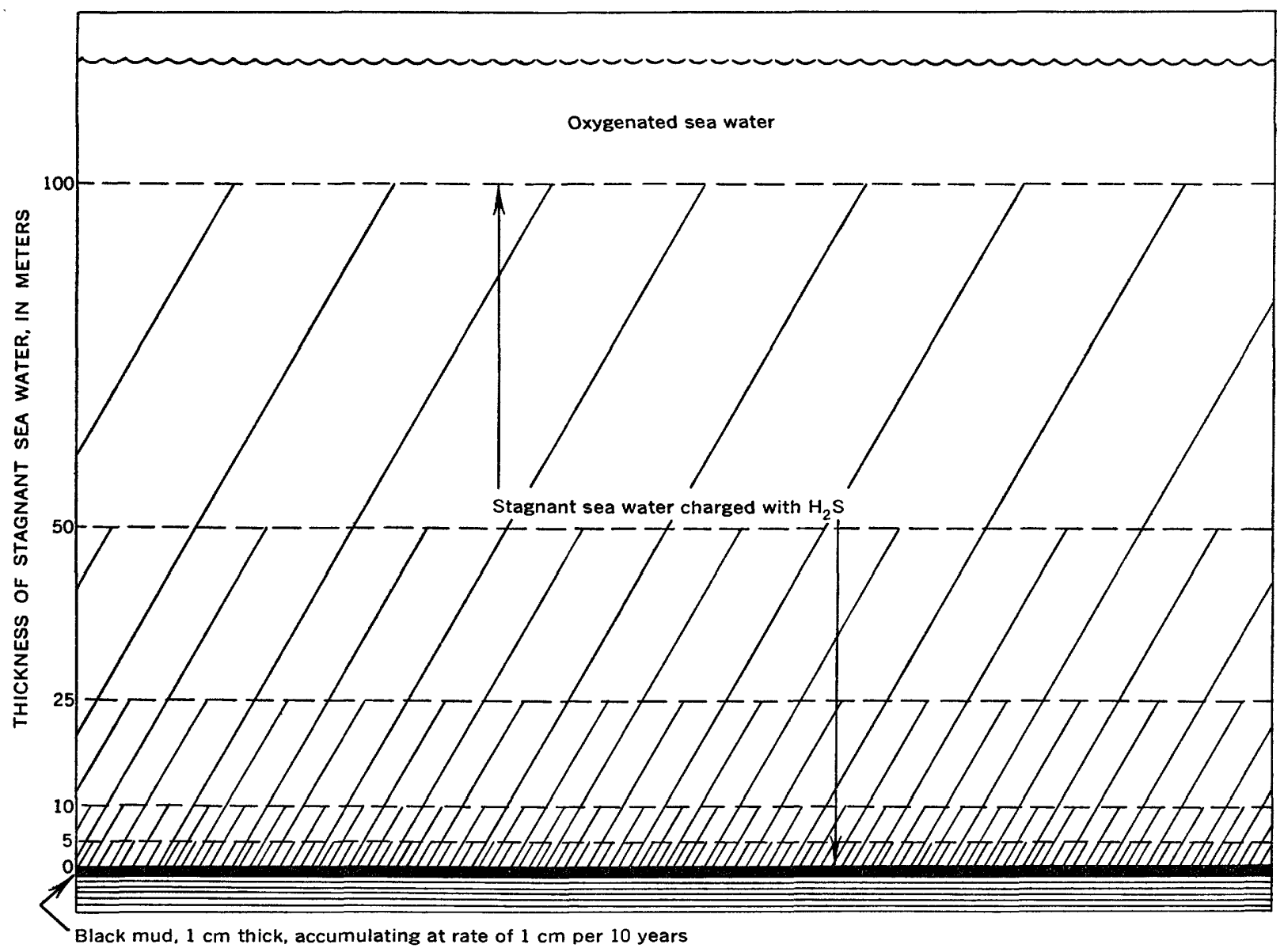

FIgdR 25.-Diagrammatic cross section of the water in a fjord showing different thicknesses of water charged with hydrogen sulfide, with corresponding calculations on the number of times this water must be changed to explain the uranium precipitated on and within a layer of bottom mud $1 \mathrm{~cm}$ thick:

\begin{tabular}{|c|c|c|c|c|c|c|}
\hline \multicolumn{2}{|r|}{ Factor } & \multicolumn{5}{|c|}{$\begin{array}{l}\text { Vertical thickness above mud of stagnant water charged } \\
\text { with } \mathrm{H}_{2} \mathrm{~S}\end{array}$} \\
\hline Symbol & Description & $100 \mathrm{~m}_{\mathrm{ft})}(328$ & $50 \mathrm{~m}_{\mathrm{ft})}(164$ & $25 \mathrm{~m}_{\mathrm{ft})}(82$ & $10 \underset{\mathrm{ft})}{\mathrm{m}}(32.8$ & $5 \mathrm{~m}_{\mathrm{ft})}(16.4$ \\
\hline $\begin{array}{l}a \\
b \\
c \\
d \\
e\end{array}$ & $\begin{array}{l}\text { Total uranium content of bottom sediment } \\
\text { Uranium content of sediment due to precipitation by } \mathbf{H}_{2} \mathrm{~S} \\
\text { Original uranium content of stangat water } \\
\text { Rate of accumulation of bottom sediment (partly compacted basis) } \\
\text { Number of times water must be replaced to explain the uranium in } 1 \mathrm{~cm} \text { of pediment } \\
\text { per 10-yr period.- }\end{array}$ & $\begin{array}{l}0.0060 \\
2 \\
1 \\
4\end{array}$ & $\begin{array}{l}0.0060 \\
2 \\
1 \\
8\end{array}$ & $\begin{array}{l}0.0060 \\
2 \\
1 \\
16\end{array}$ & $\begin{array}{l}0.0060 \\
1 \\
40\end{array}$ & $\begin{array}{l}0.0060 \\
2^{.0050} \\
1 \\
80\end{array}$ \\
\hline
\end{tabular}

times every 10 years $(e)$ to account for the uranium in the muds of fjord $X$.

Unfortunately, the desired uranium data on one of the classic examples of black mud deposition, the Black Sea, are not available, but enough is known to provide basis for speculation on the uranium content of the black muds of the Black Sea.

Most of the known and postulated chemical factors favorable for uranium concentration are identified in what is known of the chemistry of the stagnant bottom water and, in places, the organic- and sulfide-rich black muds of the Black Sea (Androussow, 1897; Archanguelsky, 1927; Pirogova, 1953; and Chilingar, 1956). At depths of 1,500 to 2,000 meters, the water contains 5 to $6 \mathrm{ml}$ of hydrogen sulfide per liter (Chilingar, 1956, p. 2766; see also Caspers, 1957, p. 809, 821) and has an Eh of about -0.2 (Skopintsev, 1956); traces of hydrogen sulfide are intermittently present at a depth of 115 to 225 meters, depending on the season, position in the sea and, presumably, the maximum depth of convection currents (Gololobov, 1953). 
The postulated process of uranium concentration by hydrogen sulfide precipitation might well apply, then, except for the previously emphasized necessity of periodic renewal of waters. Androussow (1897) concluded that it takes 1,700 years for the inflowing saline bottom water entering the Black Sea through the Strait of Bosporus to accomplish renewal of the entire salt-water content of the Black Sea; Merz and Moller, as reported by Caspers (1957, p. 820), calculated that a complete change of the water below the 30-meter surface zone takes 2,500 years. Both rates of renewal are far too slow to provide a source of soluble uranium for hydrogen sulfide precipitation sufficiently large to result in highly uraniferous sediment. If the original saline waters contained $2 \mathrm{ppb}$ uranium, all of which was released from a column of water 2,000 meters thick, the uranium content of the mud would be increased by less than $10 \mathrm{ppm}$ or 0.001 percent uranium, using the rate of sedimentation for the deepwater gray clay of the Black Sea of $0.2 \mathrm{~mm}$ per year, as determined by Archanguelsky (1927, p. 276) and recorded by Caspers (1957, p. 829). The older black clay in the Black Sea probably accumulated more slowly and, conceivably, might contain more than 0.001 percent uranium.

To the critical observer, any one or all of the factors on which these calculations on uranium in the Norwegian fjords and the Black Sea are based are variables, but one very important point stands out: If hydrogen sulfide precipitation of uranium from sea water was an important process in the concentration of uranium in black shales, periodic or intermittent renewal of the water in which they were deposited was essential, followed by periods of stagnation and production of hydrogen sulfide. During deposition of the Chattanooga shale, which probably was extremely slow in a relatively shallow epicontinental sea (probably several tens of feet to a few hundred feet deep) that contained only a few parts per billion of uranium, circulation of the waters was certainly necessary; but this circulation probably was spasmodic rather than continuous, perhaps owing to storms, to thermal inversions, or to invasions, such as have been described by Woolnough $(1937$, p. 1129, 1145), of marine waters into a large semibarred basin at infrequent intervals. The minute ripple marks, discontinuity of microscopic layers, megascopic cross lamination, and other primary structural features of the shale represent incidents in the depositional history of the shale that support this interpretation.

\section{PHOSPHATE \\ RELATION TO ORANIUM}

Phosphate $\left(\mathrm{P}_{2} \mathrm{O}_{5}\right)$, generally in the form of nodules, is a common and distinctive lithologic component of many uraniferous black shales. The uranium content of these phosphatic nodules ranges from 0.001 to nearly 0.1 percent, and the $\mathrm{P}_{2} \mathrm{O}_{5}$ content from 10 to 35 percent. In some black shale units such as the thin layers of Pennsylvanian age in the Midcontinent area (Danilchik and Hyden, 1956, p. 260; written communication, 1958), the phospate contains most of the uranium in the unit.

Phosphatic nodules 1 to 3 inches in greatest diameter are distributed sparingly through the uppermost part of the upper unit of the Gassaway member of the Chattanooga shale in parts of central Tennessee. These nodules contain 0.0030 percent or less uranium, which is less than that of the enclosing shale; of further interest is the fact that this nodule-bearing shale contains 0.0020 to 0.0030 percent less uranium than the underlying shale which has no nodules. That shale that is devoid of visible nodules and that contains the greater amount of uranium has an average content of 0.3 percent $\mathrm{P}_{2} \mathrm{O}_{5}$, and little or no uranium appears to be associated with the phosphate of this shale.

No data are available on the phosphate content of sediments from the Baltic Sea. The phosphate analyses of sediment in the Norwegian fjords (Strom, 1936, p. 61-63) was not made on the same samples that have been analysed for uranium but because the black muds of the fjords represented by both sets of samples are described in almost identical fashion, the amounts of phosphate in both sets of samples are probably very similar. The $\mathrm{P}_{2} \mathrm{O}_{5}$ contents range from 0.14 to 0.36 percent; the samples from the Gassaway member of the Chattanooga shale have a similar range in phosphate content. The phosphate in both the black fjord muds and the Chattanooga shale probably is present as an inherent constituent of the organic matter, as phosphatic shells or skeletons, and as detrital apatite.

The amounts of phosphate in the waters of the Baltic Sea were determined by Buch (1932), and his data show that the maximum phosphate values are always in the bottom waters. These bottom-water values generally range from 5 to $50 \mathrm{mg} \mathrm{P}_{2} \mathrm{O}_{5}$ per cu $\mathrm{m}$ of water, but have an average (Buch, 1932, p. 15) of $110 \mathrm{mg} \mathrm{P}_{2} \mathrm{O}_{5}$ per cu m in the Baltic Sea area from which the samples of Koczy, Tomic, and Hecht (1957, fig. 1) were collected. The maximum values reported by Buch $(1932$, p. 14) are for the bottom water of station F81, previously described on page 93 as very near the locality in the Gotland deep where Koczy, 
Tomic, and Hecht (1957, loc. 6) collected their most uraniferous samples. In 1928, 1929, and 1930, this water from depths of 200 to 220 meters contained 200,225 , and $220 \mathrm{mg} \mathrm{P}_{2} \mathrm{O}_{5}$ per cu $\mathrm{m}$, respectively.

One of the most significant observations to come out of Strom's (1936) studies of the fjord waters is that the amount of phosphate in a body of water generally increases with increasing degree of water stagnation, but that there is practically no deposition of phosphate in the black muds. The fact that phosphate is not deposited, that the waters are too poisonous to support an abundant fauna and flora which ordinarily deplete water of phosphate, and that sinking phosphatic organic remains such as shells are dissolved in these waters, probably explains the nearrecord amounts (as much as $700 \mathrm{mg} \mathrm{P}_{2} \mathrm{O}_{5}$ per cu m) of phosphate in solution in the bottom waters of the fjords.

As pointed out by Kazakov (1937) and by Krumbein and Garrels (1952, p. 9) the precipitation of phosphate is strongly dependent on the $\mathrm{pH}$ of the water, the solubility of the phosphate increasing with decreasing $\mathrm{pH}$. In the fjords, where no phosphate precipitation is known but where the amount in solution is exceedingly high, the $\mathrm{pH}$ of the bottom waters is on the acid side, or nearly neutral, ranging from 6.9 to 7.5. Because uranium is being concentrated in the black muds of the fjords and the phosphate is retained in solution, it can be firmly stated that the uranium in marine black shale can be, and in many shale units undoubtedly is, geochemically and mineralogically independent of any phosphate present in the shale. It also should be pointed out that if the $\mathrm{pH}$ of the water of the fjord were to rise to 7.5 or higher and phosphate were to be precipitated accordingly, a lesser degree of stagnation would be indicated, and the chemical system most favorable for uranium concentration by hydrogen sulfide would no longer exist. In other words, phosphate deposition may be indicative of a lesser rate of uranium accumulation, and probably is with the nodule-bearing Chattanooga shale unit described above.

\section{GEOCHEMICAI CONDITIONS FOR PHOSPHATE DEPOSITION}

The preceding discussion has been devoted primarily to those muds and shales that are almost devoid of phosphate; but, as previously stated, phosphate is the component in some shales that contains the major part of the uranium. The intimate genetic, geochemical, and stratigraphic associations of uraniferous phosphorites and black shales have been cited by many authors (for example, McKelvey and Nelson, 1950, p. 40-41; Whitehead, 1952, p. 196-198; McKelvey,
Everhart, and Garrels, 1955, p. 514; and Chentsov, 1956). The geochemistry of uranium in phosphorites is the subject of an exhaustive study by Altschuler, Clarke, and Young (1958); and Sheldon (1959) described and interpreted in detail the geochemical conditions relating to the concentration of uranium in the phosphorite and black shale of the Phosphoria formation of the Northwestern United States.

The presence or absence of phosphate in marine black shale provides a basis for developing a logical sequence of changing chemical conditions in the bottom waters of the seas where black muds are deposited, here described as involving four stages. The distribution of phosphate in the upper part of the Chattanooga shale and in the overlying Maury formation and Fort Payne chert of Mississippian age is used to illustrate this sequence, as shown in figure 26. In general, marine black shale devoid of phosphate, as in the lower part of the section in figure 26, typifies stage 1 ; and black shale containing scattered phosphatic nodules, as in the uppermost part of the Chattanooga shale, represents stage 2. Stage 3 is represented by rock composed chiefly of phosphate, only very minor amounts of carbonaceous matter, and, commonly, abundant glauconite, as present in the lower part of the Maury formation. Stage 4 in this theoretical cycle and transition of geochemical conditions is represented by limestone, commonly containing a large amount of chert, with only a very minor amount of phosphate and little or no carbonaceous matter. The Fort Payne chert is typical of stage 4 in the figured example. In application of this sequence of stages to other stratigraphic sections, the cycle may be reversed, to go from stage 4 to stage 1 , or, in beginning with stage 4 , it may be visualized as being arrested for long periods in stages 3 or 2 , before returning to stage 4 .

Chemically, the water conditions controlling the retention of phosphate in solution or the precipitation and deposition of phosphate are a result of the change from a stagnant anaerobic environment (stage 1), caused by the slow decomposition of the organic matter and poor water circulation on the bottom of the sea, to an oxygenated and more alkaline environment due primarily to water circulation wherein calcium carbonate could be deposited (stage 4). The key chemical change probably is that of $\mathrm{pH}$ (Kazakov, 1937; Krumbein and Garrels, 1952, p. 9; Smirnov, 1958), phosphate in solution being available and other factors being equal. At low $\mathrm{pH}$, about 6.5 to 7.0, the phosphate remains in solution, the phosphatic materials that settle into this water are dis- 


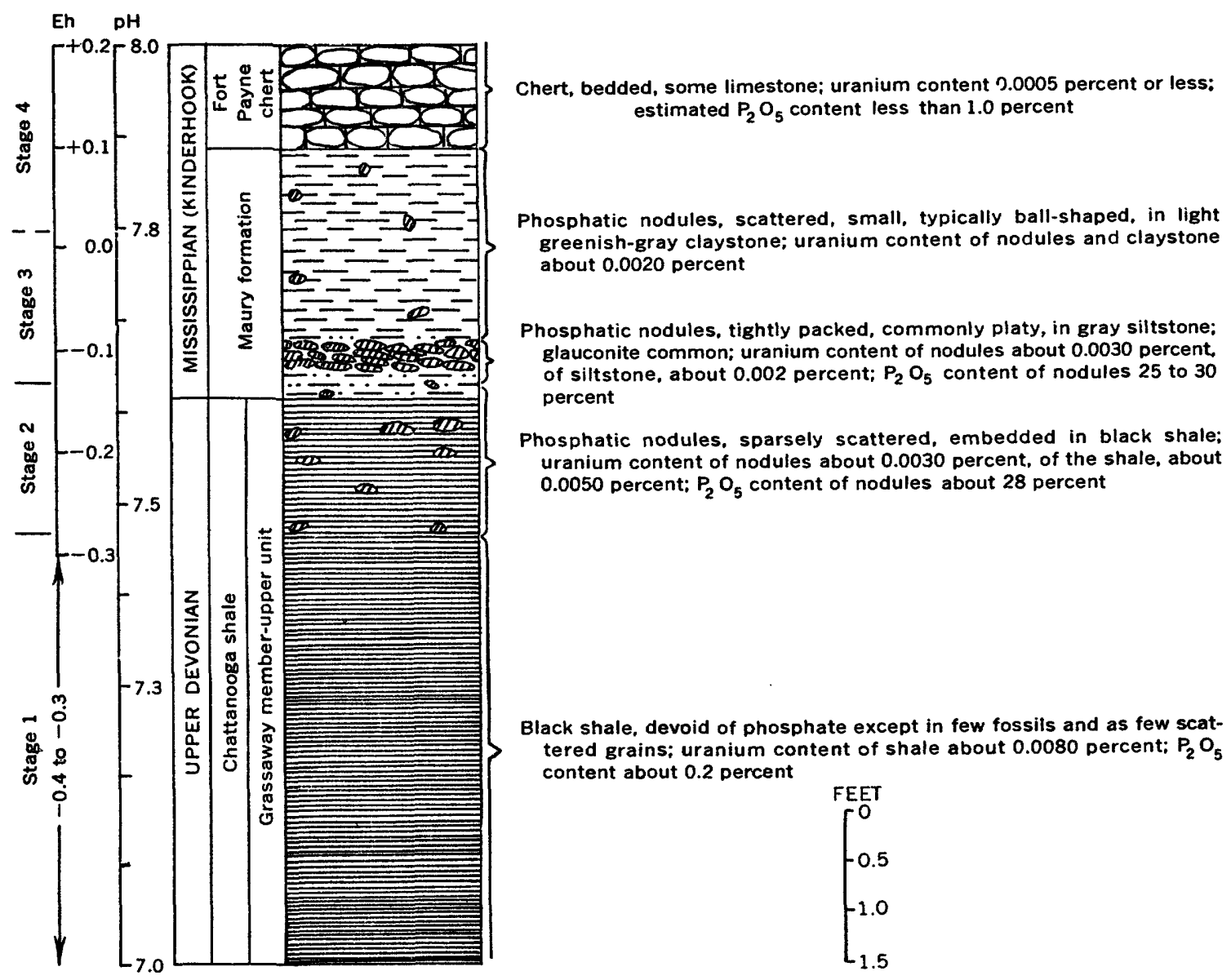

Figdri 26.-Generalized stratigraphic section of the uppermost Devonian and lowermost Mississipplan rocks in central Tennessee showing the uranium content of the different units as related to distribution of phosphate, and the interpretated $\mathrm{pH}$ and $\mathrm{Eh}$ that existed at or just above the water-sediment contact at time of deposition.

solved, and the phosphate content of the water is increased (stage 1). It is probable that as the general $\mathrm{pH}$ in this lower water rises toward about 7.5 as a result of limited water circulation, very minute and scattered centers of slightly higher $\mathrm{pH}$ are formed in the water or at the sediment-water interface, primarily around fragments of calcareous or phosphatic shells or other hard parts of pelagic animals that constitute the "seeds" for phosphate precipitation, and that phosphatic pellets or nodules start to form (stage 2). As the $\mathrm{pH}$ rises above 7.5, this precipitation of phosphate takes place more readily, and if the rise in $\mathrm{pH}$ is rapid, the precipitation of phosphate is accelerated accordingly and results in a layer of chiefly phosphatic sediment in the form of oolites, pellets, nodules, and even discontinuous laminae (stage 3). With continued rise in $\mathrm{pH}$ to about 8.0 , the originally large supply of phosphate in solution is exhausted, and phosphate becomes only a very minor constituent in the sediment accumulating in this normal sea water environment (stage 4). This theoretical sequence of phosphate deposition from sea water is in general compatible with the results of experiments by Smirnov (1958, figs. 1-3) to determine the physicochemical factors governing phosphate precipitation in sea water.

\section{CYCLE OF PHOSPHATE DEPOSITION}

In the initial stage (stage 1) no phosphate is deposited, and uranium is concentrated in the sediment by organic matter or by the action of hydrogen sulfide. During the next stage (stage 2), when only a few, very scattered nodules form and are deposited, the chemical combination of uranium in carbonate fluorapatite by ionic substitution for calcium (Altschuler, Clarke, and Young, 1958, p. 69) is in large part dependent on the availability of uranium in the waters where precipitation of phosphate takes place; if, as is considered possible in interpreting the low uranium content of the nodules in the upper part of the Chattanooga shale, the uranium in these waters had already been depleted by direct hydrogen sulfide precipitation, the resulting phosphate would have little or no uranium. On the other hand, if hydrogen 
sulfide had not reached the sphere of phosphate precipitation and uranium was available in the water, the scattered phosphatic nodules deposited during stage 2 might contain as much as several hundredths percent uranium.

During stage 3, when theoretically the major phosphate deposition takes place, sufficient water circulation is involved to result in phosphate containing 0.01 to 0.10 percent uranium. In the final stage (stage 4) where only a very minor amount of phosphate is precipitated, the phosphatic particles may have a relatively high uranium content, but because they are disseminated sparingly through nonuraniferous carbonate or siliceous sediment, the rock in which they reside rarely has more than a few parts per million uranium (0.000X percent).

Carbonate fluorapatite, or "calcium phosphate," has the capacity to take up uranium and fluorine any time after it has been deposited (Altschuler, Clarke, and Young, 1958, p. 83). This property explains the variable uranium contents of marine phosphorite, apatite, and phosphatic fossils (for example, shells and bones). Much of the uranium in the phosphate formed in the described cycle is undoubtedly syngenetic, but subsequent uptake of uranium may take place diagenetically or by later exposure of the phosphate to uranium-bearing ground water. Postsyngenetic uptake of uranium is probably insignificant in the phosphate of black shales because of the general impermeability of these shales until they are greatly weathered.

The relation of the uranium to the phosphate in a black shale and the interpreted chemical conditions prevailing in the overlying water at time of deposition are illustrated in figure 26. Here, the four stages of the cycle are illustrated, though the absence of highly uraniferous phosphatic materials in stage 3 must be explained by the lack of uranium in the waters where the phosphate was precipitated, by the abundance of calcium ions which precluded abundant ionic substitution, or by other reasons unknown.

The thin phosphatic marine black shale beds of Pennsylvanian age in the midcontinent area of the United States are believed to illustrate best stage 2 of phosphate precipitation, where uranium is associated chiefly with the phosphatic nodules and layers in the shale. It is postulated that, at the time these shale beds were deposited, the hydrogen sulfide-reducing environment was confined to the sediment, and that the uranium available in the overlying waters was fixed by the precipitating phosphate. The uraniferous phosphorite in the Phosphoria formation of southwestern Montana, southeastern Idaho, and western Wyoming probably best illustrate stage 3 in the cycle, though all 4 stages are represented within the vertical and lateral facies of this formation.

\section{othHer chemicax variables}

The $\mathrm{pH}, \mathrm{Eh}$, and salinity values are measurements of important chemical characteristics of water that are critical in understanding and determining the probable and possible chemical reactions that can take place in a complex chemical environment. To these three characteristics may be added those of temperature, pressure, density, and others, but the significance of these in the sorption or precipitation of uranium from sea water is unknown.

\section{ACIDITY}

The bottom water of both the Norwegian fjords and parts of the Baltic Sea are only very slightly acidic, about $\mathrm{pH} 7.0$ or slightly less. This lowering of the $\mathrm{pH}$ from about 8.0 in normal sea water to about 7.0 is primarily due to carbon dioxide produced by anaerobic bacteria attacking the organic matter in the bottom mud, though the soluble organic acids and the hydrogen sulfide which may be similarly produced are also weak acids. Presumably the water a few inches above the organic-rich mud may have a $\mathrm{pH}$ as low as 6.5, and the water in the mud may have a $\mathrm{pH}$ in the 5.5 to 6.5 range.

The significance of the $\mathrm{pH}$ of the sea water on the concentration of uranium in marine black mud and shale can be evaluated by noting three factors: (a) The direct effect that $\mathrm{pH}$ has in the ability and capacity of certain substances to sorb uranium; (b) the direct effect that $\mathrm{pH}$ has in the precipitation of uraniumbearing substances; (c) the indirect relations of $\mathrm{pH}$ to the uranium content of the sediment.

Rozhkova and others (1958, p. 427, 430-431) showed by a series of experiments that maximum amounts of uranium are sorbed by coaly substances and phosphorites from solutions having a $\mathrm{pH}$ of 5 to 6 ; as the $\mathrm{pH}$ increases to 8 or decreases to 3 , the sorptive capacity of these materials, which include lignite and humic acids, rapidly decreases. Manskaya, Drozdova, and Emilyanova (1956) experimented with the precipitation of uranyl humates, the uranium-bearing humic acids, as a function of $\mathrm{pH}$. Using an alkaline extract from peat, they found that the optimum production of uranyl humates, the precipitate that contains the most uranium, is at a $\mathrm{pH}$ close to 5 . In experiments using the humic acids separated from the peat extract and washed to remove the chloride ion, the $\mathrm{pH}$ optimum for precipitation of uranium in the humates is within the 5.5 to 7.0 range. These 
empirical observations indicate that the $\mathrm{pH}$ of the waters associated with black mud deposits approaches the range of $\mathrm{pH}$ wherein maximum uranium sorption can take place, because these waters have a $\mathrm{pH}$ of 6.5 to 7.5. It is probable, however, that the materials in these muds rarely sorb uranium to their full capacity, because the amount of uranium in sea water is too low or the length of time in which they are exposed to sea water having this $\mathrm{pH}$ is too short.

The direct effect of $\mathrm{pH}$ of sea water in the precipitation of uranium-bearing substances, particularly humic acids and phosphate, has been indicated in preceding sections. Manskaya, Drozdova, and Emelyanova (1956) showed that as the $\mathrm{pH}$ of alkaline water which contains dissolved humic acids is lowered, very minor coagulation of humates takes place at $\mathrm{pH}$ of 8 and production of coagulated humates increases as the $\mathrm{pH}$ is lowered to 5 , when the water is almost depleted of its humic acids. Undoubtedly, the major fraction of the uranium-bearing humic acids transported by sea water is flocculated and deposited when it meets the bottom water of black-mud seas having a $\mathrm{pH}$ in the 6.5 to 7.5 range. The precipitation of uraniumbearing phosphate has been described as being dependent on the increase of $\mathrm{pH}$ of this bottom water from 6.5 to 8.0.

Other, but indirect, relations of $\mathrm{pH}$ to the uranium content of marine muds and shales should be noted. Sea water having $\mathrm{pH}$ of 7.2 or less is probably indicative of water wherein organic matter is being decomposed and hydrogen sulfide is being produced, and where uranium is being precipitated directly from the water. It is mainly the Eh level that controls the reduction and precipitation of uranium as uraninite(?) crystallites, but commonly both $\mathrm{Eh}$ and $\mathrm{pH}$ of the water are lowered simultaneously as organic matter decomposes, so $\mathrm{pH}$ may be an indirect measure of this precipitation action. Some exceptions to the parallel rise and fall of $\mathrm{pH}$ and Eh were pointed out, however, by Emery and Rittenberg (1952, p. 770-771). Carbonate sediments will not form in waters having a $\mathrm{pH}$ less than about 7.8 (Krumbein and Garrels, 1952, fig. 8); this fact explains the general inverse relation of uranium to calcium carbonate in marine black shales, noted by McKelvey and Nelson (1950, p. 39), Swanson (1956, p. 453), and others.

\section{OXIDATION-REDUCTION POTENTIAL}

The Eh of the bottom water and of the mud in both the Norwegian fjords and the Baltic Sea can be decribed only in general terms because no direct measurements are known. A possible index of the Eh of the water, however, is the relation of oxygen to hydro- gen sulfide in the water; in general, the water that has only minute traces of both free oxygen and hydrogen sulfide may be considered as having an Eh of 0.0 volt. Because reducing conditions are most pertinent here in the discussion of processes of uranium concentration, the decrease of $\mathrm{Eh}$ from 0.0 to -0.4 volt may be crudely indicated by the proportional increase of hydrogen sulfide from a small fraction of 1 to $200 \mathrm{cu}$ cm per liter.

Biologic processes are the fundamental cause of reducing conditions in the marine environments discussed here. Aerobic bacteria consume free oxygen until it is depleted, whereupon anaerobic bacteria become established and obtain their oxygen either from the bound oxygen of the organic matter or from the sulfate ions in the saline water, with consequent release of hydrogen sulfide. The extent and "strength" of the resulting reducing conditions, or the negative Eh produced, is a function of the rate and length of time of anaerobic decomposition in stagnant water. Given abundant organic matter in the bottom sediment, and still water above, reducing conditions will be established in the bottom water fairly rapidly; it is thus conceivable that water which is circulated intermittently or infrequently actually may be reducing in character for cumulatively long periods of time; the probability of this being true for large epeiric blackshale seas in the past as well as in the fjords today was described in detail by Strøm (1955).

The Eh of the black mud sediment is always low and generally is of negative potential (Zobell and Feltham, 1942; Emery and Rittenberg, 1952, p. 775), except for the uppermost inch or two of sediment during times of ventilation. That a negative Eh existed in the sediment through diagenesis and until Recent weathering set in is indicated by the abundant organic matter and iron-sulfide minerals preserved in black shales.

A general review of uranium geochemistry indicates that it is doubtful that salinity, which is a quantitative measure of the total dissolved solids in water, can in itself be an important factor in the geochemical processes of uranium precipitation and concentration in sediments. Salinity measurements can be used, however, to indicate the amount and distribution of uranium in sea water.

In the Baltic Sea, which is partially restricted from free ocean-water circulation, the salinity of the water ranges from a few to about 35 parts per thousand, the latter typical of normal sea water. In parts of the Baltic a positive correlation between uranium content and salinity of the waters is indicated (Karlik, 1939, 
p. 12-13; Koczy, Tomic, and Hecht, 1957, p. 95), but the probable underlying explanation for this relation is that the inflowing marine water of high salinity contain 2 to 3 times more uranium than the average river water entering the basin. The uranium content of the waters of the Norwegian fjords has not been studied, but if the river water feeding a fjord has a significantly different uranium content from the marine water that periodically invades the fjord from the sea, salinity determinations also could be expected to be a crude measure of uranium content of the water.

Of the several geochemical parameters discussed, the value of interpreted salinities of ancient seas in understanding uranium concentration in shale is believed minimal, particularly when the salinity of an ancient sea is a type of second-order interpretation, based on interpretations of paleogeography and paleoecology.

\section{DIAGENETIC CHANGES IN BLACK MUDS}

In the descriptions, data, and interpretations in the preceding part of this paper, emphasis has been placed on the chemical systems and processes prevailing in the water overlying black mud deposits; the genesis of several components of mud and shale, particularly uranium, has been related directly to the chemical nature of the overlying water. Very little attention has been paid to the chemical processes and changes active within the mud deposits themselves. To some, this apparent omission may be basis for serious criticism, for several studies (for example, Emery and Rittenberg, 1952; Strakhov, 1953; Debyser, 1957) have decisively shown that the present chemical and mineralogic organization of many marine sedimentary rocks is largely dependent on the major chemical reorganization that occurred during early diagenesis of the sediment.

No studies have been made to demonstrate that uranium is redissolved, migrates, and is refixed within a black mud after the mud is deposited; actually, the diffuse dissemination of uranium in shales strongly indicates that there were no diagenetic changes in the distribution, form, and associations of uranium.

Most studies of physicochemical changes during diagenesis have been concerned with chemical conditions in modern sediment that can not be compared or related to the black mud environment which is of special interest in this paper. These studies of modern sediment (reviewed by Strakhov, 1953) have shown that the major chemical changes which occur during diagenesis are dependent primarily on the position of the boundaries between the oxidizing and reducing zones and between the alkaline and acid or near neu- tral zones within the deposited sediment. Under these circumstances, iron, for example, is deposited in its higher valent or oxidized state. When buried to depths of several inches to about a foot it is enveloped in a zone of reducing and even slightly acid conditions, whereupon it is dissolved and reduced, it may be transported laterally and vertically in intrasediment solutions, and may be finally fixed, commonly concentrated, in positions and in mineralogic forms that are grossly different from its primary depositional state. Obviously, the products of such chemical diagenetic changes in a sedimentary rock can not be related directly to the chemical system prevailing in the water above the surface of deposition, but, rather, are related directly to the chemical system prevailing within the sediment long after deposition and burial.

In the marine black mud environment, the critical $\mathrm{Eh}$ and $\mathrm{pH}$ boundaries are not a few inches or feet down in the deposited sediment but generally are a few inches to several tens of feet above the surface of deposition. Much, if not most of the dissolution, reduction, redistribution, and refixation or reprecipitation of sediment components is accomplished prior to sediment deposition, or at least before the diagenetic stage. This latter generalization does not preclude possible diagenetic transformation and redistribution of some minerals within the black muds, such as some sulfide compounds and clays, but it is very unlikely that uranium is so affected. Further, there should be very little similarity between the physicochemical changes characterizing the diagenetic history of modern sediments deposited in oxygenated alkaline water and these changes in mud deposited in strongly reducing and slightly acid water; drastic chemical diagenetic changes characterize the former, and relatively minor changes the latter.

The author, therefore, has adopted the viewpoint that the observed components and chemical characteristics of highly uraniferous marine black shale can be related directly to the originally deposited sediment and directly to the chemical system peculiar to the stagnant overlying water of a marine basin. As the water became less stagnant, these direct relations gradually were obscured, and chemical diagenetic processes gradually became more active.

The major physical change in muds during diagenesis probably is the decrease in volume by compaction because of burial by younger sediments (Weller, 1959). The initial water content of marine mud is in the 50 to 95 percent range, and this water content is reduced to less than 1 to about 5 percent on the burial 
of the mud and its transformation to shale. Compaction results in some reorientation of grains in the sediment, in the obliteration of some primary structural features, and in some structural bending of softer materials around almost incompressible substances; however, the net effect of compaction on the distribution of uranium is negligible, other than that associated with simple volume change.

\section{SUMMARY}

Utilizing the results of four types of studies, the most probable geologic controls and geochemical processes involved in the concentration of uranium in marine black shales are presented. These four types of studies are: (a) geologic studies on uraniferous marine black shales, chiefly represented by a part of the Chattanooga shale; (b) sedimentologic studies on modern uranium-bearing black mud of the Norwegian fjords and the Baltic Sea; (c) oceanographic or hydrographic studies on modern sea water in which this mud is deposited; and (d) organic and inorganic chemical studies involving laboratory experiments in uranium precipitation under conditions related to those observed in the first three categories.

The exact chemical and physical state of most of the uranium in marine black muds and shales is not known. The uranium is in its reduced state, but the proportions of this uranium held by sorption to organic matter, fixed in an organic molecule, or distributed as colloidal-sized uranium minerals have not been determined. Therefore, the form and manner of emplacement of uranium must be interpreted on the basis of known interrelations of other constituents in the sediment and of known chemical processes active in the environment of black mud deposition.

\section{FACTORS CONTROLLING URANIUM DISTRIBUTION IN BLACK SHALES}

Fourteen variable factors have been postulated in the literature and in this report as controlling the uranium content of marine black muds and shales. These factors are divided into two groups, $A$ and $B$, on the basis of whether their quantitative significance is speculative or demonstratable. The factors of speculative significance are:

Group $A$ :

1. Type of rocks composing the source area.

2. Rate and type of weathering of these source rocks.

3. Uranium content of stream waters.

4. Relative distance of mud deposition from mouths of rivers.
5. Uranium content of sea water.

6. Depth of sea water and rate and pattern of circulation of sea water.

7. Amount of planktonic organisms in the sea water capable of concentrating its uranium.

8. Rate of sediment deposition.

9. Amount of iron sulfide in sediment.

10. Amount of calcium carbonate in sediment. The following factors may be measured or supported by chemical or geologic evidence:

Group $B$ :

1. Uranium in organic matter:

a. Uranium inherent to living plants or animals, either land or marine types.

b. Uranium sorbed from sea water by either solid or colloidal remains of plankton settling from surface water to bottom.

c. Uranium sorbed from stream and sea waters by either solid or colloidal organic matter derived from decaying land plants and deposited from suspension or as precipitated humates.

2. Uranium, probably as colloidal-size uraninite, reduced and precipitated from sea water in hydrogen sulfide environment:

a. Uraninite(?) precipitated from connate water, where hydrogen sulfide environment is confined to sediment; pyrite also forms in sediment.

b. Uraninite(?) precipitated from sea water, where hydrogen sulfide is generated within sediment and diffuses into overlying waters; pyrite also forms within sediment.

3. Uranium in phosphate (carbonate-fluorapatite) precipitated from sea water and incorporated by ionic substitution for calcium:

a. Uranium in phosphate precipitated from sea water depleted in uranium and amassed on and within sediment as sparse oolites and nodules; also uranium in phosphatic fossil shells and bones.

b. Uranium in phosphate precipitated from, settling through, and exposed to sea water above sediment-water interface. 
4. Uranium in clastic mineral sediment, landderived:

a. Uranium in main mass of sediment, particularly clay minerals which have sorbed uranium.

b. Uranium in heary minerals such as zircon, apatite, and sphene.

Each of the factors in group $A$ can be argued, largely by deductive reasoning, to have an influence on the amount of uranium in a black shale. Some of these variable factors, particularly $1,2,3,4$, and 7 , are so conjectural and have such an indirect bearing as to be next to meaningless; their importance has been emphasized in the past, but on a closer look they are found to involve so many assumptions and highly subjective interpretations as to render them of doubtful and unknown significance.

Factors 5 and 6 have a more direct bearing on the problem, because they can be evaluated in semiquantitative terms and with fewer assumptions; however, it is unlikely that ancient sea water contained any more than the $3 \mathrm{ppb}$ uranium that modern sea water contains. The depth and the rate and pattern of circulation of sea water can be shown to be of fundamental importance if much of the uranium in black muds and shales was precipitated from sea water, but the magnitude of these parameters in ancient seas obviously involves considerable guesswork. The rate of sediment deposition (factor 8) is also of critical importance because of the diluting effect of nonuraniferous sediment; it is included in this group of factors of speculative significance because it too must be evaluated on an "other-factors-being-equal" basis, though these other factors are markedly fewer than those in the evaluations of the preceding items.

The amounts of iron sulfide and of calcium carbonate (factors 9 and 10) in black muds and shales can be precisely determined by chemical means, but neither is combined chemically with uranium, and the quantitative relations of each to amounts of uranium in the muds and shales may be largely fortuitous. It is true that all uranium-bearing black muds and shales have abundant iron sulfide, but the reverse situation does not hold. A negative correlation between the amount of uranium and the amount of calcium carbonate deposited in a black mud theoretically could result only where a delicately parallel rise and fall of $\mathrm{pH}$, which largely controls carbonate precipitation, and of oxidation-reduction potential (Eh), which may control uranium accumulation, took place in the bottom waters; a constant supply of both the constituents also would have to exist. Thus, iron sulfide or calcium carbonate might serve as suggestive and in- direct evidence of the presence or absence, respectively, of uraniferous shale; however, they provide no firm basis for quantitative evaluations of the uranium content of marine black muds and shales.

In group $B$, each of the major factors are of undoubted importance in determining the uranium content of marine black muds and shales. The subfactors $(a, b, c)$ of the major items are less well differentiated, but are at least theoretically distinguishable, and are recommended points of departure for future research in solving problems of uranium distribution.

Within group $B$, most of the phosphate (factor 3) and the clastic sediment (factor 4 ) can be physically separated from the rest of the sediment and the uranium content of each determined directly. The amount of uranium attributable to the organic matter (factor 1) and to direct precipitation in the hydrogen sulfide environment (factor 2) are not so readily determined. Existing methods for isolating chemically undisturbed organic matter and subdividing it into its several types for uranium analysis are inadequate. The uranium precipitated in the hydrogen sulfide environment is so intimately associated with the organic matter, and to some extent with the clastic sediment, as to defy existing separation techniques, and even microscopic and autoradiographic differentiation.

Until laboratory techniques are developed that will unquestionably segregate the several components in group $B$, the amount of uranium assignable to each must be estimated on the basis of total uranium content, of analyses of the best available, but still impure, organic and mineral fractions, and of the theoretical considerations which follow.

\section{KNOWN AND THEORETICAC RELATIONS}

\section{SOURCE OF URANTUM}

Most of the uranium in marine black muds and shales was derived from sea water. Present-day sea water contains about $3 \mathrm{ppb}$ of uranium, which is in the highly soluble form of uranyl and uranyl complex ions. For the following reasons, no real basis is believed to exist for concluding that the main mass of water in ancient black-shale seas contained significantly more or less uranium, or different forms of uranium: (a) Several studies on the general history of the composition of sea water indicate that it has changed very little since early geologic time; (b) studies in Russia indicate that no correlation exists between the uranium content of sedimentary rocks and the age of these rocks; (c) no epicontinental seas of today are known to have a uranium content significantly different from that of the open seas; (d) the 
uranium content of some modern black mud is very similar to that of many ancient black shales; (e) differences in uranium content of black shales can be better ascribed to variability and effectiveness of pertinent processes of uranium concentration than to differences in the uranium content of sea water; and ( $f$ ) the volume and mobility of as dilute a uranium solution as sea water makes it an ample reservoir of uranium for any black shale or modern mud, and definitely makes an academic question of the probability of several parts per billion, more or less, in ancient seas.

For these reasons, the general availability of uranium in seas of the past can be compared directly with that in modern basins of deposition. For the main mass of sea water this availability of uranium is here taken to be $3 \mathrm{ppb}$ of uranium; data on the Baltic Sea and Norwegian fjords indicate that the epicontinental seas of the past contained 1 to $3 \mathrm{ppb}$. The stagnant water immediately above the bottom of the seas where black muds are accumulating probably is depleted in uranium and contains less than $1 \mathrm{ppb}$ of uranium for intermittent, and probably long, periods of time. It is under these circumstances that the availability of uranium should be considered.

\section{ORGANIC MATTMGR}

The relation of organic matter to uranium in marine black shales and muds must still be discussed in general terms because of inadequate information. It is unlikely that much uranium was assimilated during the living stage of the original organisms; rather, uranium was withdrawn from the sea water at some stage after death and during decomposition and deposition of the organic remains. The questions of kinds and proportions of these uranium-fixing substances in marine muds and shales and of whether they were derived from land or were locally derived from plankton have not been answered.

Some geologic evidence, strongly supported by results of laboratory experiments, indicates that the humic type of organic matter has the greatest affinity for uranium. Solid humic matter, such as wood fragments, and the soluble humic substances generally termed "humic acids" adsorb or complex the uranium in its uranyl form from stream and marine waters enroute to the place of deposition. The solid humic matter is deposited from suspension, and the humic acids are precipitated as humates either by coming into contact with the divalent cations common to more saline water or on entering the slightly acidic bottom water characteristic of the black mud environment. On entering the black mud environment, the uranyl uranium attached to organic substances is reduced to its uranous form.

\section{HYDROGEN SULFIDI}

Hydrogen sulfide is a common product of decomposition of organic matter by anaerobic bacteria in modern sediment and of bacterial reduction of the sulfate ions in the water within and overlying this sediment. Subsequent combination of this hydrogen sulfide with ferrous iron in the sediment results in the formation of iron sulfides, which are present in abundance as iron monosulfide in black muds and as pyrite in most uraniferous black shales. The formation of hydrogen sulfide and consequent formation of pyrite in much organic-rich sediment is confined below the surface of mud deposition; but, where there is little or no circulation of the overlying water, hydrogen sulfide rises into and becomes concentrated in the bottom water.

Laboratory experiments have demonstrated that uranium in solution is readily reduced and precipitated as uranium oxide on introduction of hydrogen sulfide into the solution; the minimum amounts of uranium and hydrogen sulfide that are necessary to result in uranium reduction and precipitation have not been determined, but, until otherwise shown, this mechanism must be considered as an important one in the syngenetic concentration of uranium from sea water into black muds and shales.

The black muds of the Norwegian fjords contain as much as 0.0060 percent uranium, and the water overlying these muds contain from a few to as many as $199.5 \mathrm{cu} \mathrm{cm}$ hydrogen sulfide per liter of water. If the uranium in these muds was precipitated by the action of hydrogen sulfide, the overlying water must have been renewed many times to explain the amount of uranium in these muds, which is dependent mainly on the vertical thickness of the water charged by hydrogen sulfide.

The general conclusion of laboratory studies on the Chattanooga shale is that, though much of the uranium in the shale is not directly associated or chemically bound by the organic matter, the uranium was probably deposited in the shale because of the presence of organic matter. The precipitation of ultramicroscopic disseminated uranous oxide by the hydrogen sulfide produced in the presence of decomposing organic matter best explains the findings of these studies. The abundant pyrite in the Chattanooga shale indirectly attests to the abundance of hydrogen sulfide in the mud of the Chattanooga sea at the time of deposition, and it is likely that the hydrogen sulfide was diffused into the overlying water between times 
of intermittent water circulation to precipitate the uranium available in the water.

\section{PHOSPHATE}

Uranium is known to be chemically bound to the phosphate, and proportional to it, in some phosphorite formations and in some black shales having abundant phosphatic layers and nodules. Parts of the Chattanooga shale and the black muds in the Norwegian fjords, however, contain only traces of phosphate but relatively large amounts of uranium, with no apparent relation between the two components. From what is known about the concentration of uranium in the fjord muds and from the fact that the abundant phosphate in the lower fjord waters is not deposited, it appears that uranium can be geochemically and mineralogically independent of phosphate, as it apparently is in many marine black shales.

Four stages that determine the precipitation of uraniferous phosphate in a changing chemical environment in the bottom waters of a marine basin are postulated. The key chemical change in this four-stage cycle is one of $\mathrm{pH}$. Stage 1 is characterized by $\mathrm{pH}$ of about 6.5 to 7.0 and is the stagnant, reducing environment in which organic-rich muds are deposited and preserved; at this $\mathrm{pH}$, phosphate in the settling organic remains is dissolved and concentrated in solution in the bottom water, though uranium may be reduced and precipitated as uraninite (?) and may be deposited in the nonphosphatic black mud. Stage 2 is a transition from stage 1 where the $\mathrm{pH}$ of the water rises to near 7.5 and the first phosphate is precipitated and deposited, generally as nodules, which are then associated with the organic-rich muds. The amount of uranium in these nodules is dependent on the limited availability of uranium in the water from which the phosphate is precipitated; if much of the uranium in the water has been withdrawn by precipitation during stage 1 , these nodules may contain only 0.0010 to 0.0030 percent uranium.

Stage 3 is indicated by the increase above 7.5 of $\mathrm{pH}$ of the bottom water, a consequence of some circulation and oxygenation of the water; only minor amounts of organic matter are preserved in the sediment, and abundant phosphate commonly is precipitated during this stage in the form of oolites, nodules, and discontinuous layers. If these phosphatic materials are precipitated slowly from waters not previously depleted in uranium, they may contain as much as 0.1 percent uranium. Stage 3, where the $\mathrm{pH}$ of the water has increased to near 8.0 owing to increased circulation and oxygenation, is characterized by deposition of calcium carbonate and (or) silica, with little or no carbonaceous material being preserved; phosphate precipitation is minimal and is disseminated through the deposited sediment. Though this phosphate may be as uraniferous as that precipitated during stage 3, it is rarely abundant enough to make the enclosing sediment contain more than 0.0002 percent uranium.

\section{pH, Eh, AND SALINITY}

The $\mathrm{pH}, \mathrm{Eh}$, and salinity are three measurable parameters of a chemical environment indicative of the general conditions in sea water favorable for the concentration of uranium in black shale. The $\mathrm{pH}$ and Eh in the bottom water of a marine basin are controlled in large part by the rate and type of decomposition of the deposited organic matter. The $\mathrm{pH}$ under these conditions, as suggested by measurements in the Norwegian fjords and the Baltic Sea, is slightly acid or near neutral, 6.5 to 7.5, and the Eh negative, 0.0 to -0.4 , both distinctly abnormal for a marine environment. The acidity of the bottom water in the black mud environment may cause the precipitation of soluble humic substances, uranyl humates, which can assimilate uranium ions to more than 5 percent by dry weight while enroute in their soluble state from land areas to these bottom waters. The role of $\mathrm{pH}$ in the precipitation of phosphate was described on page 104.

The mechanism of reduction and precipitation of uranium from sea water, as effected under negative Eh conditions, involves the action of hydrogen sulfide.

Geochemical processes involving uranium deposition apparently are independent of varying salinity of the water, though differences in salinity values may indicate differences in uranium content of the water. The Baltic Sea studies show that if a significant difference exists between the uranium content of the fresh water entering a basin and the uranium content of the marine water in the basin, salinity measurements may indicate the amount of uranium in the mixed waters.

\section{CONCLUSION}

In conclusion, a graph is presented (fig. 27) that shows the best estimates that can be made at the present time on the distribution and associations of uranium in marine black muds and shales. The precise amount of uranium allotted to each uranium-bearing constituent in each of the muds and shales is largely theoretical, and may be as much as 100 percent in error. This probable error will be reduced only when the several black shales and muds are studied in greater detail and the applicability and efficiency of geochemical processes of uranium enrichment in organic-rich muds and shales are unequivocally and quantitatively defined. 


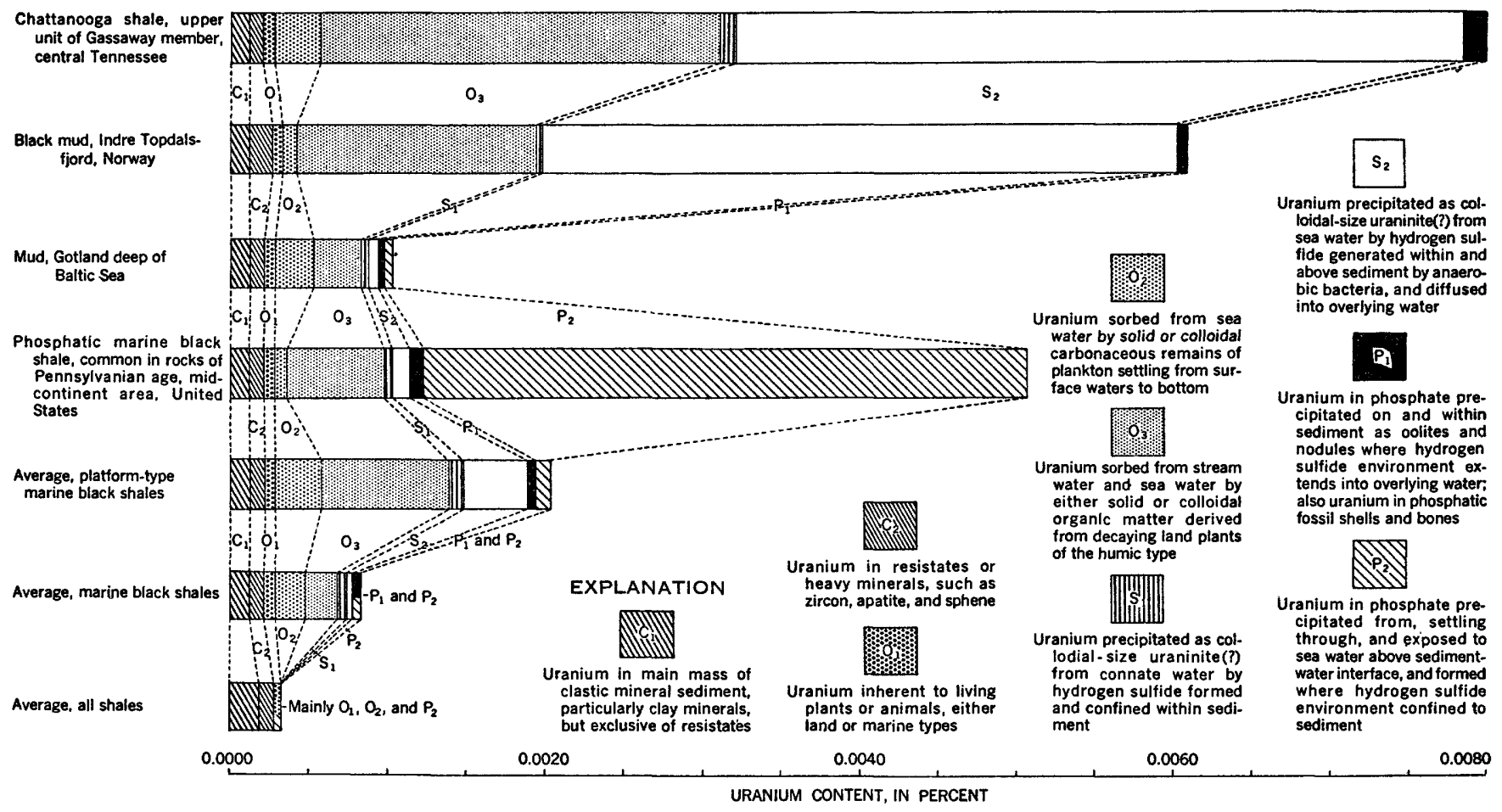

FIGURT 27.-Graph showing estimated average amount contributed to the total uranium content by nine uranium-bearing constituents of shales and muds.

\section{LITERATURE CITED}

Abraham, Herbert, 1945, Asphalts and allied substances: New York, D. Van Nostrand Co. Inc., v. 1, 887 p.

Alekin, O. A. and Moricheva, N. P., 1958, The influence of the carbonate system in natural waters on the content of organic substances: Akad. Nauk SSSR Doklady, v. 119, no. 2, p. 322-325; as seen in English translation by Consultants Bureau, Inc., New York, 1958.

Altschuler, Z. S., Clarke, R. S., Jr., and Young, E. J., 1958, The geochemistry of uranium in apatite and phosphorite: U.S. Geol. Survey Prof. Paper 314-D, p. 45-90.

Androussow, N., 1897, La Mer Noire [The Black Sea]: Guide Excursion $7^{\mathrm{e}}$ Cong. Géol. Internat., St. Petersbourg, 29th, $13 \mathrm{p}$.

Archanguelsky, A. D., 1927, On the Black Sea sediments and their importance for the study of sedimentary rocks [English] : Moscow Soc. Naturalists Bull., Geol. Sec., v. 5, no. 3-4, p. 264-289.

Bain, G. W., 1950, Geology of the fissionable materials: Econ. Geology, v. 45, p. 273-323.

- 1956, Reconnaissance for uranium in the Phosphoria formation: U.S. Atomic Energy Comm. RME-3141, 64 p., issued by U.S. Atomic Energy Comm. Tech. Inf. Service, Oak Ridge, Tenn.

Baranov, V. I., Ronov, A. B., and Kunashova, K. G., 1957, K geokhimil rasseyannogo toriya $i$ urana $v$ glinah i karbonatyh porodah russkoi platformy [On the geochemistry of dispersed thorium and uranium in clays and carbonate rock of the Russian platform] : Geokhimiya, no. 3, p. 3-8.

Barnes, H., 1957, Nutrient elements: Geol. Soc. America Mem. 67, v. 1, p. 297-344.
Bates, T. F., and Strahl, E. O., 1956, Regional study of the mineralogy and petrology of the Chattanooga shale [abs.] : Geol. Soc. America Bull., v. 67, p. 1669.

- 1957, Mineralogy, petrography, and radioactivity of representative samples of Chattanooga shale: Geol. Soc. America Bull., v. 68, p. 1305-1314.

- 1958, Mineralogy and chemistry of uranium-bearing black shales: Second Internat. Conf. on Peaceful Uses of Atomic Energy Proc., Geneva, 1958, v. 2, p. 407-411.

Bates, T. F., and others, 1956, An investigation of the mineralogy, petrography, and paleobotany of uranium-bearing shales and lignites; scope $A-$ shales, fifth ann. rept.: U.S. Atomic Energy Comm. NYO-7411, 106 p., issued by U.S. Atomic Energy Comm. Tech. Inf. Service, Oak Ridge, Tenn.

Beers, R. F., 1945, Radioactivity and organic content of some Paleozoic shales: Am. Assoc. Petroleum Geologists Bull., v. 29 , no. 1, p. 1-22.

Beers, R. F., and Goodman, Clark, 1944, Distribution of radioactivity in ancient sediments: Geol. Soc. America Bull., v. 55, no. 10 , p. 1229-1259.

Bell, K. G., 1954, Uranium and thorium in sedimentary rocks, in Faul, Henry, ed., Nuclear geology: New York, John Wiley \& Sons, Inc., p. 98-114.

Breger, I. A., and Deul, Maurice, 1956, The organic geochemistry of uranium, in Page, Stocking, and Smith: U.S. Geol. Survey Prof. Paper 300, p. 505-510.

Breger, I. A., and Schopf, J. M., 1955, Germanium and uranium in coalified wood from Upper Devonian black shale: Geochim. et Cosmochim. Acta, v. 7, nos. 5-6, p. 287-293.

Brown, Andrew, 1956, Uranium in the Cattanooga shale of eastern Tennessee, in Page, Stocking, and Smith: U.S. Geol. Survey Prof. Paper 300, p. 457-462. 
Buch, Kurt, 1932, Untersuchungen über geloste Phosphate und Stickstoffverbindungen in den Nordbaltischen Meeresgebieten [English summary with title "Investigation of phosphate and nitrogen compounds in the waters of the North Baltic"] : Finland Havsforskningsinstitutet Merentut. Julk., no. 86,30 p.

Carroll, Dorothy, 1958, Role of clay minerals in the transportation of iron: Geochim. et Cosmochim. Acta, v. 14, nos. 1-2 p. 1-27.

Caspers, Hubert, 1957, Black Sea and Sea of Azov: Geol. Soc. America Mem. 67, v. 1, p. 801-890.

Chentsov, I. G., 1956, On the mode of occurrence of uranium in phosphate rocks: Atomnaja Energiya, v. 1 no. 5, p. 113 ; Jour. Nuclear Energy, 1957, v. 5, pt. 2, p. 146-148.

Chilingar, G. V., 1956, Black Sea and its sediments, a summary: Am. Assoc. Petroleum Geologists, v. 40, no. 11, p. 2765-2769.

Clarke, F. W., 1924, The data of geochemistry: U.S. Geol. Survey Bull. 770, 841 p.

Colorado School of Mines Research Foundation, Inc., 1957, Phase two--Study of the effects of crude oll constituents on the reduction and precipitation of uranium: U.S. Atomic Energy Comm. RME-3149, 21 p., issued by U.S. Atomic Energy Comm. Tech. Inf. Service, Oak Ridge, Tenn.

Conant, L. C., 1956, Environment of accumulation of the Chattanooga shale, in Page, Stocking, and Smith: U.S. Geol. Survey Prof. Paper 300, p. 463-467.

Conant, L. C., and Swanson, V. E., 1961, Chattanooga shale and related rocks of central Tennessee and nearby areas: U.S. Geol. Survey Prof. Paper 357 (in press).

Corbett, C. S., 1955, In situ origin of McMurray oil of northeastern Alberta and its relevance to general problem of origin of oil: Am. Assoc. Petroleum Geologists Bull., v. 39, no. 8, p. 1601-1621.

Curtis, Diane, 1957, Selected annotated bibliography of the geology of uranium-bearing phosphorites in the United States: U.S. Geol. Survey Bull. 1059-B, p. 29-58.

Danilchik, Walter, and Hyden, H. J., 1956, Midcontinent Pennsylvanian rocks, in Geologic investigations for radioactive deposits, semiannual progress report, Dec. 1, 1955 to May 31, 1956: U.S. Geol. Survey TEI-620, p. 259-261, issued by U.S. Atomic Energy Comm. Tech. Inf. Service, Oak Ridge, Tenn.

Debyser, Jacques, 1957, Contribution à l'étude des sédiments organiques de la mer Baltique; relation entre le $\mathrm{pH}$, le $\mathrm{Eh}$, et la diagénèse [Contribution to the study of organic sediments of the Baltic Sea; relation of $\mathrm{pH}$ and $\mathrm{Eh}$ to diagenesis] : Inst. Francais Pétrole Rev., v. 12, no. 1, p. 3-13.

Denson, N. M., Zeller, H. D., and Stephens, J. G., 1956, Water sampling as a guide in the search for uranium deposits and its use in evaluating widespread volcanic units as potential source beds for uranium, in Page, Stocking, and Smith : U.S. Geol. Survey Prof. Paper 300, p. 673-680.

Deul, Maurice, 1955, Mode of occurrence of uranium in the Chattanooga shale [abs.] : Econ. Geology, v. 50, p. 772; Geol. Soc. America Bull., v. 66, p. 1549.
1957, Geochemistry of uranium-bearing shales, in Geologic investigations of radioactive deposits, semiannual progress report, June 1 to Nov. 30, 1957: U.S. Geol. Survey TEI-700, p. 213-224, issued by U.S. Atomic Energy Comm. Tech. Inf. Service, Oak Ridge, Tenn.

Deul, Maurice, and Breger, I. A., 1954, Geochemistry of uranium-bearing shales, in Geologic investigations of radioactive deposits, semiannual progress report, June 1 to Nov. 30, 1954: U.S. Geol. Survey TEI-490, p. 178-182, issued by U.S. Atomic Energy Comm. Tech. Inf. Service, Oak Ridge, Tenn.

Duncan, D. C., 1953, Reconnaissance investigations for uranium in black shale deposits of the Western States during 1951 and 1952: U.S. Geol. Survey TEI-381, 89 p., issued by U.S. Atomic Energy Comm. Tech. Inf. Service, Oak Ridge, Tenn.

Dunham, R. J., 1954, Black shale, Chadron area, Nebraska and South Dakota, in Geologic investigations of radioactive deposits, semiannual progress report, June 1 to Nov. 30, 1954: U.S. Geol. Survey TEI-490, p. 157-158, issued by U.S. Atomic Energy Comm. Tech. Inf. Service, Oak Ridge, Tenn.

Eargle, D. H., and Hollingsworth, J. V., 1958, Radioactivity and uranium content of Eagle Ford rocks of Texas, in Geologic investigations for radioactive deposits, semiannual progress report, June 1 to Nov. 30, 1957: U.S. Geol. Survey TEI-700, p. 172-174, issued by U.S. Atomic Energy Comm. Tech. Inf. Service, Oak Ridge, Tenn.

Emery, K. O., and Rittenberg, S. C., 1952, Early diagenesis of California basin sediments in relation to origin of oil: Am. Assoc. Petroleum Geologists Bull., v. 36, no. 5, p. 735-806.

Ewing, B. B., Drynan, W. R., and Gloyna, E. F., 1955, Recovery of uranium from saline solutions by biological slimes: U.S. Atomic Energy Comm. ORO-148, 33 p., issued by U.S. Atomic Energy Comm. Tech. Inf. Service, Oak Ridge, Tenn.

Ferm, J. C., 1955, Radioactivity of coals and associated rocks in Beaver, Glearfield and Jefferson Counties, Pennsylvania: U.S. Geol. Survey TEI-468, 52 p., issued by U.S. Atomic Energy Comm. Tech. Inf. Service, Oak Ridge, Tenn.

Fix, C. E., 1958, Selected annotated bibliography of the geology and occurrence of uranium-bearing marine black shales in the United States: U.S. Geol. Survey Bull. 1059-F, p. 263-325.

Fix, P. F., 1956, Hydrogeochemical exploration for uranium, in Page, Stocking, and Smith: U.S. Geol. Survey Prof. Paper 300, p. 667-671.

Fleming, R. H., 1957, General features of the oceans: Geol. Soc. America Mem. 67, v. 1, p. 87-108.

Galliher, E. W., 1933, The sulfur cycle in sediments: Jour. Sed. Petrology, v. 3, no. 2, p. 51-63.

Garrels, R. M., 1955, Some thermodynamic relations among the uranium oxides and their relation to the oxidation states of the uranium ores of the Colorado Plateau: Am. Mineralogist, v. 40, p. 1004-1021.

Glebov, S. M. 1941, Radioaktivnost diktionemovykh slantsev [Radioactivity of Dictyonema shales]: Leningrad, Leningradski Gornyi Inst., จ. 14, p. 1-12. 
Glover, Lynn, 1959, Stratigraphy and uranium content of the Chattanooga shale in the folded belt of Alabama, Georgia, and Tennessee: U.S. Geol. Survey Bull. 1087-E, p. 133168.

Goldschmidt, V. M., 1954, Geochemistry: Oxford, Clarendon Press, 730 p.

Gololobov, Ya. Ka., 1953, The thickness of the oxygen-hydrogen sulfide layer in the Black Sea: Akad. Nauk SSSR Gidrokhim. Materialy, v. 21, p. 3-9; as seen in Chem. Abs., 1954, v. 48, no. 11126e.

Gott, G. B., and Hill, J. W., 1953, Radioactivity in some oil flelds of southeastern Kansas: U.S. Geol. Survey Bull. 988-E, p. 69-122.

Granquist, Gunnar, 1982, Croisier thalassologique et observations en bateaux routiers en 1981 [Thalassological cruise and observations on the boat route in 1931]: Finland Havsforskningsinstitutet Merentut. Julk., no. 81,38 p.

- 1933a, The thalassological summer cruise in 1982: Finland Havsforskningsinstitutet Merentut. Julk., no. 89, $16 \mathrm{p}$.

- 1933b, The thalassological summer cruise in 1933 : Finland Havsforskningsinstitutet Merentut. Julk., no. 90, $16 \mathrm{p}$.

Gripenberg, Stina, 1934, A study of the sediments of the North Baltic and adjoining seas: Finland Havsforskningsinstitutet Merentut. Julk., no. 96, 231 p.; also Fennia, v. 60 , no. 3, 231 p.

Gripenberg, Stina, 1955, Sediments of the Baltic Sea, in Trask, P. D., ed., Recent marine sediments-a symposium: Soc. Econ. Paleontologists and Mineralogists Spec. Pub. 4, p. 298-321.

Gruner, J. W., 1952, New data of synthesis of uranium minerals: U.S. Atomic Energy Comm. RMO-983, 26 p., issued by U.S. Atomic Energy Comm. Tech. Inf. Service, Oak Ridge, Tenn.

Gruner, J. W., Rosenzweig, Abraham, and Smith, D. K., Jr., 1953, Progress report for April 1 to October 1, 1953 : Minnesota Univ., U.S. Atomic Energy Comm. RME-3060, 9 p., issued by U.S. Atomic Energy Comm. Tech. Inf. Service, Oak Ridge, Tenn.

Harvey, H. W., 1955, Biological oceanography, in Trask, P. D., ed., Recent marine sediments-a symposium: Soc. Econ. Paleontologists and Mineralogists Spec. Pub. 4, p. 142-152.

Hass, W. H., 1956, Age and correlation of the Chattanooga shale and the Maury formation: U.S. Geol. Survey Prof. Paper 286, 47 p.

Hecht, Friedrich, Kupper, Heinrich, and Petrascheck, W. E., 1958, Preliminary remarks on the determination of uranium in Austrian springs and rocks: Second Internat. Conf. on Peaceful Uses of Atomic Energy Proc., Geneva, 1958, v. 2, p. 158-160.

Hernegger, Friedrich, and Karlik, Berta, 1935, Uranium in sea water: Göteborgs Kgl. Vetensk.-Vitterhets-Samhäll. Handl., ser. B, b. 4, no. 12,15 p.

Holland, H. D., and Kulp, J. L., 1954, The transport and deposition of uranium, ionium, and radium in rivers, oceans, and ocean sediments: Geochim. et Cosmochim. Acta, v. 5, p. 197-213.

Holmes, Arthur, 1981, Radioactivity and geological time: Natl. Research Council Bull. 80, pt. 4, p. 124-459.
Huber, N. K., 1958, The environmental control of sedimentary iron minerals: Econ. Geology, v. 53, no. 2, p. 123-140.

Hutchinson, G. E., 1957, A treatise on limnology: New York, John Wiley \& Sons, Inc., 1015 p.

Jaffe, Gilbert, and Hughes, J. H. 1953, The radioactivity of bottom sediments in Chesapeake Bay: Am. Geophys. Union Trans., v. 34, no. 4, p. 539-542.

Jensen, M. L., 1958, Sulfur isotopes and the origin of sandstone-type uranium deposits: Econ. Geology, v. 53, no. 5, p. 598-616.

Karlik, Berta, 1939, The uranium content of sea water: Göteborgs Kgl. Vetensk,-Vitterhets-Sämhall. Handl., ser. B., v. 6 , no. 12 , p. $7-14$.

Kazakov, A. V., 1937, The phosphorite facies and the genesis of phosphorites in Geological investigations of agricultural ores, U.S.S.R.: U.S.S.R. Sci. Inst. Fertilizers and Insectofungicides Trans., no. 142, p. 95-113. (Special issue published in Fnglish for 17th Internat. Geol. Cong.)

Kehn, T. M., 1955, Uranium in the Chattanooga shale, Youngs Bend area, Eastern Highland Rim, Tennessee: U.S. Geol. Survey TEI-528-A, 60 p., issued by U.S. Atomic Energy Comm. Tech. Inf. Service, Oak Ridge, Tenn.

Kepferle, R. C., 1959, Uranium in Sharon Springs members of Pierre shale, South Dakota and northeastern Nebraska : U.S. Geol. Survey Bull. 1046-R, p. 577-604.

Kessler, L., 1857, Procédés de préparation et d'analyse de l'oxyde d'Urane [Procedures for the preparation and analysis of uranium oxide]: Jour. de Pharmacie et des Sci. Accessoires, v. 31, p. 182-183.

Kinney, C. R., and Schwartz, Donald, 1957, Partial air oxldation of Chattanooga uraniferous black shale: Indust. and Eng. Chem., v. 49, no. 7, p. 1125-1130.

Klepser, H. J., 1957, An investigation of the Chattanooga black shale of Tennessee as a source of uranium, progress report for July 1, 1956 to June 30, 1957 : U.S. Atomic Energy Comm. ORO-167, 11 p., issued by U.S. Atomic Energy Comm. Tech. Inf. Service, Oak Ridge, Tenn.

Koczy, F. F., 1954, Geochemical balance in the hydrosphere, in Faul, Henry, ed., Nuclear geology: New York, John Wiley \& Sons, Inc., p. 120-127.

1956, Geochemistry of the radioactive elements in the ocean: Deep Sea Research, v. 3, no. 2, p. 93-103.

Koczy, F. F., Tomic, Ernst, and Hecht, Friedrich, 1957, Zur Geochemie des Urans im Ostseebecken [The geochemistry of uranium in the Baltic Sea]: Geochim. et Cosmochim. Acta, v. 11, nos. 1-2, p. 86-102.

Korolev, D. F., 1958, The role of Iron sulfides in the accumulation of molybdenum in sedimentary rocks of the reduced zone: Geochemistry, a translation of Geokhimiya [SSSR], v. 4, p. 452-463.

Krumbein, W. C., and Garrels, R. M., 1952, Origin and classification of chemical sediments in terms of $\mathrm{pH}$ and oxidation-reduction potentials: Jour. Geology, v. 60 , no. 1 , p. 1-33.

Krumbein, W. C., and Slack, H. A., 1956, Statistical analysis of low-level radioactivity of Pennsylvanian black fissile shale in Illinois: Geol. Soc. America Bull., v. 67, p. 739762. 
Kurbatov, L. M., 1936, Radioaktivnost donnykh otlozhenil morei i ozer SSSR [On the radioactivity of bottom sediments of seas and lakes of U.S.S.R.]: Arktika, no. 4, p. 95-105, Leningrad.

Kurbatov, L. M., and Ermolaev, M. M., 1937, On the radioactivity and chemical composition of the bottom sediments of Kara Sea: Problemy Arktiki, no. 2, p. 67-70, Leningrad, Vses. Arkticheski i Institut.

Landis, E. R., 1958, Radioactivity and uranium content of Devonian and Mississippian black shales in the central Midcontinent area, in Geologic investigations of radioactive deposits, semiannual progress report, Dec. 1, 1957, to May 31, 1958: U.S. Geol. Survey TEI-740, p. 202-208, issued by U.S. Atomic Energy Comm. Tech. Inf. Service, Oak Ridge, Tenn.

- 1959, Radioactivity and uranium content of Sharon Springs member of Pierre shale and associated rocks in western Kansas and eastern Colorado: U.S. Geol. Survey Bull. 1046-L, p. 299-319.

Larsen, E. S., Jr., Phair, George, Gottfried, David, and Smith, W. L., 1956, Uranium in magmatic differentiation, in Page, Stocking, and Smith: U.S. Geol. Survey Prof. Paper 300, p. $65-74$.

Larsson, A., 1919, Ur Mina Anteckningar, II-Uran och radium 1 kolm [Uranium and radium in kolm]: Svensk Kem. Tidskr., v. 31, p. 63-70, Stockholm.

McKelvey, V. E., 1955, Search for uranium in the United States : U.S. Geol. Survey Bull. 1030-A, p. 1-64.

McKelvey, V. E., Everhart, D. L., and Garrels, R. M., 1955, Origin of uranium deposits: Econ. Geology, 50th anniversary volume, p. 464-533.

McKelvey, V. E., and Nelson, J. M., 1950, Characteristics of marine uranium-bearing sedimentary rocks: Econ. Geology, v. 45, p. 35-53.

MacPherson, H. G., 1958, A chemical and petrographic study of Precambrian sediments: Geochim. et Cosmochim. Acta, v. 14, nos. 1-2, p. 73-92.

Manskaya, S. M., Drozdova, T. V., and Emelyanova, M. P., 1956, Sviazyvanic urana guminovymi kislotami i melanoidinami [Binding of uranium by humic acids and melanoidines] : Geokhimiya, v. 4, p. 10-23.

Mapel, W. J., 1956a, Uraniferous black shale in the northern Rocky Mountains and Great Plains regions, in Page, StockIng, and Smith: U.S. Geol. Survey Prof. Paper 300, p. 469476.

- 1956b, Uranium in black shale deposits, northern Rocky Mountains and Great Plains: U.S. Geol. Survey Bull. 1030-E, p. 211-235.

Miller, L. J., 1958, The chemical environment of pitchblende: Econ. Geology, v. 53, no. 5, p. 521-545.

Moore, G. W., 1954, Extraction of uranium from aqueous solution by coal and some other materials: Econ. Geology, v. 49 , no. 6 , p. $652-658$.

Munthe, H., Westergard, A. H., and Lundquist, G., 1928, Beskrivning till Kartbladet Skövde [Description of the Skovde map]: Sveriges Geol. Undersökning, no. 121, 182 p., Stockholm.

Nininger, R. D., 1954, Minerals for atomic energy: New York, D. Van Nostrand Co., Inc., 367 p.
Nordenskiöld, A. E., 1893, Remarques sur le fer natif d'Ovifak et sur le bitume des roches cristallines de Swede [Remarks on the native iron of Ovifak and on the bitumen in the crystalline rocks of Sweden]. Extrait d'une lettre de $M$. Nordenskiöld à $M$. Daubrée: Acad. Sci. Paris Comptes Rendus, v. 116, p. 677-678.

Orlov, N. A., and Kurbatov, L. M., 1934-1936, K voprosu o radioaktivnosti gorluchikh slantser [Radioactivity of combustible shales]: Khim. Tverd. Topliva, v. 5 (1934), p. 525-527; v. 6 (1935), p. 278-291; v. 7 (1936), p. 94-98.

Ostrom, M. E., Hopkins M. E., White, W. A., and McVicker, L. D., 1955, Uranium in Illinois black shales: Illinols State Geol. Survey Circ. 203, 15 p.

Page, L. R., Stocking, H. E., and Smith, H. B., compllers, 1956, Contributions to the geology of uranium and thorium by the United States Geological Survey and Atomic Energy Commission for the United Nations International Conference on Peaceful Uses of Atomic Energy, Geneva, Switzerland, 1955: U.S. Geol. Survey Prof. Paper 300, $739 \mathrm{p}$.

Patterson, E. D., 1954a, Radioactive coal and shale of Pennsylvanian and Permian age in northern West Virginia: U.S. Geol. Survey TEI-494, 17 p., issued by U.S. Atomic Energy Comm. Tech. Inf. Service, Oak Ridge, Tenn.

$1954 \mathrm{~b}$, Radioactivity of part of the bituminous coal region of Pennsylvania : U.S. Geol. Survey TEI-479, 44 p., issued by U.S. Atomic Energy Comm. Tech. Inf. Service, Oak Ridge, Tenn.

1955, Radioactivity of some coals and shales in southern Illinois: U.S. Geol. Survey TEI-466, 23 p., issued by U.S. Atomic Energy Comm. Tech. Inf. Service, Oak Ridge, Tenn.

Pirogova, M. V., 1953, Chemical exchange between the bottom of the Black Sea and the overlying water layers: Akad. Nauk SSSR Gidrokhim. Materialy, v. 21, p. 10-18; as seen in Chem. Abs., 1954, v. 48, no. $11126 f$.

Pliler, Richard, and Adams, J. A. S., 1959, Distribution of thorium and uranium in a Pennsylvanian weathering profile [abs.]: Geol. Soc. America Bull., v. 70, no. 12, pt. 2, p. 1656-1657.

Pollara, F. Z., Levine, N., Killelea, J. R., Musa, R. C., and Hassialis, M. D., 1958, Recovery of uranium from Chattanooga shale: Indus. and Eng. Chem., v. 50, no. 12, p. 1750-1753.

Rafalsky, R. P., 1958, The experimental investigation of the conditions of uranium transport and deposition by hydrothermal solutions: Second Internat. Conf. on Peaceful Uses of Atomic Energy Proc., Geneva, 1958, v. 2, p. 432444.

Redfield, A. C., 1958, The biological control of chemical factors in the environment: Am. Scientist, v. 46, no. 3, p. 205-221.

Rona, E., Gilpatrick, L. O., and Jeffrey, L. M., 1956, Uranium determination in sea water: Am. Geophys. Union Trans., v. 37, no. 6, p. 697-701.

Rona, E., and Urry, W. D., 1952, Radioactivity of ocean sediments, VIII; Radium and uranium content of ocean and river waters: Am. Jour. Sci., v. 250, p. 241-262. 
Rozhkova, E. V., Rasumnaya, E. G., Serebryakova, M. B., and Shcherbak, O. V., 1958, The role of sorption in the process of uranium concentration in sedimentary rocks: Second Internat. Conf. on Peaceful Uses of Atomic Energy Proc., Geneva, 1958, v. 2, p. 420-431.

Rubey, W. W., 1951, Geologic history of sea water: Geol. Soc. America Bull., จ. 62, no. 9, p. 1111-1147.

Runnels, R. T., Schleicher, J. A., and Van Nortwick, H. S., 1953, Composition of some uranium-bearing phosphate nodules from Kansas shales: Kansas Geol. Survey Bull. 102 , pt. 3, p. 93-104.

Russell, W. L., 1944, The total gamma ray activity of sedimentary rocks as indicated by Geiger counter determinations: Geophysics, v. 9, no. 2, p. 180-216.

- 1945, Relation of radioactivity, organic content, and sedimentation: Am. Assoc. Petroleum Geologists Bull., v. 29 , no. 10 , p. $1470-1494$.

Schuchert, Charles, 1915, The conditions of black shale deposition as illustrated by Kupferschiefer and Lias of Germany : Am. Phil. Soc. Proc., v. 54, p. 259-269.

Segerstråle, S. G., 1957, Baltic Sea : Geol. Soc. America Mem. 67 , v. 1 , p. $751-800$.

Sheldon, R. P., 1959, Geochemistry of uranium in phosphorites and black shales of the Phosphoria formation: U.S. Geol. Survey Bull. 1084-D, p. 83-115.

Skopintsev, B. A, 1956, Oxidation-reduction potential of waters of the Black Sea: U.S.S.R. Acad. Sci. Proc., Geochem. Sec., v. 108, no. 6, p. 1120; as seen in English translation by Consultants Bureau, Inc., New York, 1956.

Smirnov, A. I., 1958, The problem of the genesis of phosphorites: Doklady Akad. Nauk SSSR, v. 119, no. 4, p. 745-749; as seen in English translation by Consultants Bureau, Inc., New York, 1958.

Snider, J. L., 1953, Reconnaissance for uranium in coal and shale in southern West Virginia and southwestern Virginia: U.S. Geol. Survey TEI-409, 28 p., issued by U.S. Atomic Energy Comm. Tech. Inf. Service, Oak Ridge, Tenn.

1954a, Reconnaissance for uranium in the Indiana coal field: U.S. Geol. Survey TEM-784, 26 p., issued by U.S. Atomic Energy Comm. Tech. Inf. Service, Oak Ridge, Tenn.

- 1954b, Radioactivity of some coal and shale of Pennsylvanian age in Ohio: U.S. Geol. Survey TEI-404, 22 p., issued by U.S. Atomic Energy Comm. Tech. Inf. Service, Oak Ridge, Tenn.

Stewart, D. C., and Bentley, W. C., 1954, Analysis of uranium in sea water: Science, v. 120, p. 50-51.

Stockdale, P. B., 1955, An investigation of the Chattanooga black shale of Tennessee as a source of uranium, progress report-Jan. 1, 1955 to June 30, 1955: U.S. Atomic Energy Comm. ORO-143, 11 p., issued by U.S. Atomic Energy Comm. Tech. Inf. Service, Oak Ridge, Tenn.

Strakhov, N. M., 1953, Diagenesis of sediments and its significance in sedimentary ore formation: Izvestiya Akad. Nauk SSSR Ser. Geol., no. 5, p. 12-49; as seen in English translation by Associated Tech. Services, East Orange, N. J., 1958.
Str $\varnothing m$, K. M., 1936, Land-locked waters; hydrography and bottom deposits in badly ventilated Norwegian fjords with remarks upon sedimentation under anaerobic conditions: Norske Videnskaps-Akad. Skrifter, no. 7, p. 1-85, Oslo.

- 1937, Two land-locked fjords in northern Norway: Norske Videnskaps-Akad. Skrifter, no. 7, 12 p., Oslo.

-1948, A concentration of uranium in black muds : Nature, จ. 162 , p. 922 .

1955, Land-locked waters and the deposition of black muds, in Trask, P. D., ed., Recent marine sediments-a symposium: Soc. Econ. Paleontologists and Mineralogists Spec. Pub. 4, p. 356-372.

Sverdrup, H. U., Johnson, M. W., and Fleming, R. H., 1942, The oceans: New York, Prentice-Hall, Inc., 1087 p.

Swanson, V. E., 1953, Uranium in the Chattanooga shale [abs.] : Geol. Soc. America Bull., v. 64, p. 1481.

- 1956, Uranium in marine black shales of the United States, in Page, Stocking, and Smith: U.S. Geol. Survey Prof. Paper 300, p. 451-456.

- 1960, Oil yield and uranium content of black shales: U.S. Geol. Survey Prof. Paper 356-A, 44 p.

Swanson, V. E., and Vine, J. D., 1958, Uranium in organic substances from two alpine meadows, Sierra Nevada, Callfornia, in Geologic investigations of radioactive deposits, semiannual progress report, Dec. 1, 1957 to May 31, 1958: U.S. Geol. Survey TEI-740, p. 209-214, issued by U.S. Atomic Energy Comm. Tech. Inf. Service, Oak Ridge, Tenn.

Szalay, A., 1954, The enrichment of uranium in some brown coals in Hungary : Acad. Sci. Hungaricae, Acta Geol., v. 2, nos. 3-4, p. 299-310.

- 1958, The significance of humus in the geochemical enrichment of uranium: Second Internat. Conf. on Peaceful Uses of Atomic Energy Proc., Geneva, 1958, v. 2, p. 182-186.

Tolmachev, U. M., 1943, Adsorbtziya uranilovykh solei na tverdykh adsorbentakh [Adsorption of uranyl salts on solid adsorbants]: Akad. Nauk SSSR Izv., Otd. Khim. Nauk, no. 1, p. 28-35.

Tourtelot, H. A., 1956, Radioactivity and uranium content of some Cretaceous shales, central Great Plains: Am. Assoc. Petroleum Geologists Bull., v. 40, p. 62-83.

Trask, P. D., 1955, Organic content of recent marine sediments, in Trask, P. D., ed., Recent marine sediments-a symposium: Soc. Econ. Paleontologists and Mineralogists Spec. Pub. 4, p. 428-453.

Urry, W. D., and Piggot, C. S., 1942, Radioactivity of ocean sediments, V; Concentration of the radio-elements, and their significance in red clay: Am. Jour. Sci., v. 240, p. 93-103.

U.S. Bureau of Mines, 1954, Synthetic liquid fuels; pt. 2 of Oil from oil shale: U.S. Bur. Mines Rept. of Inv. 5044, $55 \mathrm{p}$.

Vine, J. D., Swanson, V. E., and Bell, K. G., 1958, The role of humic acids in the geochemistry of uranium: Second Internat. Conf. on Peaceful Uses of Atomic Energy Proc., Geneva, v. 2, p. 187-191. 
Vinogradov, A. P., 1953, The elementary chemical composition of marine organisms: Yale Univ. Sears Found. Marine Research Mem. 2, 647 p.

Waksman, S. A., 1933, On the distribution of organic matter in the sea bottom and the chemical nature and origin of marine humus: Soil Science, v. 36, p. 125-147.

- 1936, Humus: Baltimore, The Williams \& Wilkens Co., $494 \mathrm{p}$.

Wedow, Helmuth, Jr., 1954, Reconnaissance for radioactive deposits in the Eagle-Nation area, east-central Alaska, 1948: U.S. Geol. Survey Circ. 316, 9 p.

Welch, S. W., 1953a, Radioactivity of coal and associated rocks in the coal fields of eastern Kentucky and southern West Virginia: U.S. Geol.. Survey TEI-347A, 38 p., issued by U.S. Atomic Energy Comm. Tech. Inf. Service, Oak Ridge, Tenn.

1953b, Radioactivity of coal and associated rocks in the anthracite fields of eastern Pennsylvania : U.S. Geol. Survey TEI-348, 31 p., issued by U.S. Atomic Energy Comm. Tech. Inf. Service, Oak Ridge, Tenn.

Weller, J. M., 1959, Compaction of sediments: Am. Assoc. Petroleum Geologists Bull., v. 43, no. 2, p. 273-310.
White, M. G., 1952, Reconnaissance for radioactive deposits along the upper Porcupine and lower Coleen Rivers, northeastern Alaska: U.S. Geol. Survey Circ. 185, 13 p.

Whitehead, W. L., 1952, Studies of the effect of radioactivity in the transformation of marine organic materials into petroleum hydrocarbons, in Report of Progress-fundamental research on occurrence and recovery of petroleum, 1950-1951: Am. Petroleum Inst., p. 192-201.

1954, Hydrocarbons formed by the effects of radioactivity and their role in the origin of petroleum, in Faul, Henry, ed., Nuclear geology: New York, John Wiley \& Sons, Inc., p. 195-218.

Woolnough, W. G., 1937, Sedimentation in barred basins, and source rocks of oil : Am. Assoc. Petroleum Geologists Bull., v. 21, no. 9 , p. 1101-1157.

Yoshimura, S., and Wadi, T., 1938, Hydrogen sulfide and ferrous sulfide in the bottom muds of brackish-water Lake Hamanko: Acad. Japan Proc., v. 14, p. 115-120.

Zobell, C. E., and Feltham, C. B., 1942, The bacterial flora of a marine mud flat as an ecological factor: Ecology, $\mathbf{\nabla} .23$, no. 1 , p. 69-78. 


\section{INDEX}

$\Delta$

Page

Acldity, laboratory experiments......... 78, 87,98-99 modern marine muds...................... 77, 98 Norwegian fjords........................ 77, 96 relation to precipftation of phosphate..... 96,97 Acknowledgments............................... 69

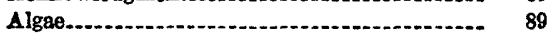
Alum shale, of Sweden, uranlum content..... 68, $82,83-84$ Anlmals, possible source of enrichment....... $89-90$ Antrim shale, studied for uranium content... 72 Appalachia, granitic landmass, possible source of uranium in Chattanooga shale...

\section{B}

Baltic Sea, chemical data on bottom sediment and water........................ 79,83 modem marine muds, acidity organic matter_........................... 76,87-89 oxddation-reduction potential.............. 77, 99

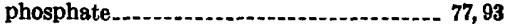
salinity............................... 77, 99-100 source of uranium, summary............... 105 sulfides_................................ 76, 91,93 uranium content..................... 76, 79,87, 93 See also Sea water, modern.

Batelle Memorial Institute, studies on Chattanooga shale...................... 71, 79

Bentonite, in Chattanooga and Plerre shales $\quad 85$ Black, defined in relation to shale............. 69-70 Black Sea, example of black mud deposition... 94-95 Black shale, defined............................ 69-70

Calcium carbonate, relation to phosphate deposition _................... 96-98 relation to urantum in black shale........ 99 Calleo Bluft formation, studied for uranium content.......................... 72 Callixylon, most uraniferous constituent in Chattanooga shale_................ 86, 87

Oarbonaceous shale, synonymous with black shale.................................... 69

Oarbonate fluorapatite, capacity to take up uranlum...................... 78, 98,101

Categorles of studies....................... 75, 76-77

Center Hill Reservoir, Tenn., potential uranlum source area....................

Chattanooga shale, bentonite............... 85 compared to alum shale of Sweden......... 82 composition.............................. 70,88, 00 example of uraniferous marine black shale. $76-$

fossils.................................. 86, 87,89,80 investigated 1944-57 for uranium content- 71 ,

$72,73,74$

organic matter $\quad 76,86$ phosphate content............... 77, 95, 96, 97, 105 probable environment of deposition....... 95 pyrite..................................... 76,90-91 relation of hydrogen sulfide, conclusion of laboratory studies............. 103-104, 105 596519-61
Chattanooga shalo-Continued Page relation of uranium to phosphate, summary.......................... 104, 105 source of uranium content..................... 83 sulfides.................................. 76, 90-91 uranium content.................. 76, 85,87,95, 105

See also Uraniferous black shale.

Chemical variables. See Variables.

Cherokee shale, studied for uranium content.. 72 Compaction of muds...................... 93, 100-101

Conclusions. $71,74,104-105$

\section{D}

Definitions............................... 69-70,86, 87 Diagenetic changes in black muds........... 100-101 Dictyonema shale, previous studies.............. 68,83 source of uranium ........................ 83

\section{E}

Eagle Ford shale, studied for uranium content.

Experlmental data ............................ 71, $72,73,78-79,87,88,90,92,93,98-99,103-104$ F

Field studies.................................... 70-73 Foerstia, in uraniferous marine black shales... 86,89 Fort Payne chert................................ 96, 97

Fossils, Chattanooga shale.................. 86,89, 00 Framvaren Fjord, hydrogen sulfide in black mud...............................................

G

Galena, in Chattanooga shale.

Gassaway member. See Chattanooga shale.

Granitic terrane, possible source of uranium in sea water....

Gotland deep. See Baltic Sea.

Gullmarfjord, uranium content................. 81-82

H

Hartville formation, studied for uranium content studi 72,73

Heath formation, studied for uranium content _........................ 72,73

Hellefjord, sulfide in bottom water............ 92

Humates, defined........-............... 87 uranium content.......................... 88, 103 Humic acids, extracted from Chattanooga shale............................. 88 known and theoretical relations.......... 103, 105 mechanism of enrichment................ $78,87,89$ source.................................... 87, 88,89

Humic type of organic matter, deflned......... 86

Hydrogen sulfide, Baltic Sea............. 77, 79, 92-93 Black Sea

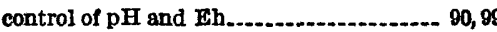
known and theoretical relations, sum. mary ....................... 103-104, 105 laboratory experiments................. 78, 90, 92, 93 Norweglan fjords...................... 77, 79, 92-93 posstble extrapolations and interpretatlons................................. $93-96$
Hydrogen sulfido-Continued Page precipltation of uranium................. 78,90-91 relation to pyrite....................... 90

$91-92,93,103$

Indre Topdalsfjord, hydrogen sulfide in bottom water.

Investigations for uniferous black shales, 1944-57.......... 70-74 Iron sulfide. See Sulfides.

Laboratory studies. See Experimental data.

$\mathbf{M}$

Marcasite, in Chattanooga shale.

Marino black shale and mud, chomical con stituents and properties control ling concentration of uranium in .. 76-77

Marine fossils, characteristic of marine black shale..... 70

Maury formation, typical of one stage of phos. phate deposition.................. 96, 97

Mechanisms of enrichment, chemical vartables.............................. 980

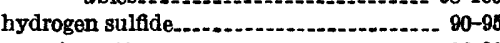
organic matter............... 86-00

phosphate Mechanisms of transportation of uranium.... 81 Muds, examples of uranium-bearing .......... 76-80 modern marine, acidity hydrogen sulfide.................. 76, 103, 105 organic-matter, content............... 76, 86-87 oxidation-reduction potential....... 77,91,99 phosphate_........................ 77,95, 104 See also Norwegian fjords, modern marine muds.

\section{$\mathbf{N}$}

Nonmarine black shale, characteristics......... Norweglan fjords, chemical dats on bottom sediment and water............ 76-77,79 modern marine muds, acidity ............. 77, 98 hydrogen sulfide..... 76, $90,92-93,94,103,105$ organic matter............................ 76, oxidation-reduction potential........... 77,99 phosphate-_._._..................... 77,95 salinity_............................... 77, 100 uranlum............................ 76, 83,86,90 uranium content of water............ 79,81-82, 100

Organic matter, correlation with uranium in Chattanooga shale.................. 91 in Chattanooga shale............. 76, 86, 87, 88, 88 in modern marine muds. . in modern sea water......................... 88-88 in uraniferous marine black shale......... 70 known and theoretical relations, sum. mary ........................... 103, 10 laboratory experiments............ $78,87,88,91,08$ 
Organic matter-Continued mechanism of enrichment, amounts and types............................... 86-87 humic acids..................... 78, 87-89, 103 incorporated by living plants and antmals................... 89-90, 103, 105 solid............... 87-88 ypes defined......

Oxidation-reduction potential, critical bound-
ary and theoretical relations, sum mary laboratory experiments................. 78-79, 90 mechanism of enrichment................. 99 modern sea water and marine muds....... 77, 99 uraniferous marine black shale.............. 99

Pennsylvania State University, studies on Chattanooga shale.... 72, 80, 86, 88, 90, 91 Pennsylvanian black shales, investigation of uranium content............... 71,72,73 relation of phosphate to uranium..... 95, 98, 105 pH of marine water, Baltic Sea..... 77, 79, 93, 98, 104 normal sea water............... $77,97,81,98$ Norwegian fjords................... 77, 79, 98, 104 relation to precipitation, humic acids....- 78 , $87,98-99$

phosphate $96-97,104$ uranium............................... 78, 98-99, 104 Phosphate, Chattanooga shale....... 77, 95, 96, 97, 105 cycle of deposition geochemical conditions for deposition .... 96-97 in modern marine muds.................. 77, 95 in modern sea water..................... 77, 79, 93

known and theoretical relations, summary laboratory experiments. mechanism of enrichment................. 95-98 relation to uranium.... $71,73,77,95-96,97,98,105$

Phosphatic nodules. See Phosphate.

Phosphoria formation ........................ 71, 73, 98

typical of one stage of phosphate deposition -

Physicochemical changes. See Diagenetic changes in black muds.

Pierre shale, bentonite. studied for uranium content

Plants, possible source of enrichment......... 89-90

Previous studies....................... 68, 70-74 See also Experimental dats.

Purpose, of investigations reviewed in study.. 70, 71 of study............ 68-69
Page

Pyrite, in Chattanoogs shale relation to hydrogen sulfide............. 91, 93, 103

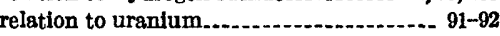

Salinity, known and theoretical relations, summary 104 laboratory experiments.................... 79 mechanism of enrichment............... 99-100 modern marine waters............... 77, 79, 99-100 Sapropelic type of organic matter, defined.... 86 Scope of report................................. 74,81 Sea water, ancient, uranium content and source

chemical variables, summary ............. 104 influence of source rock on uranium content laboratory experiments 78 mechanism of transportation of uranium. 85,103 modern, acidity ................. 77, 98 hydrogen sulfide..................... 76,93-95 organic-matter content.... $76,88-89$ oxidation-reduction potential.......... 77,99 phosphate content.................. 77, 95-96 salinity - 77, 99-100 uranium content ............. 76, 81-82, 83,84 only logical source of uranium in marine black shale. . . . . . source and chemical form of uranium con-

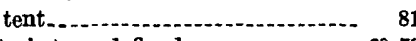
Shale, lithologic term defined. Sharon Springs member. See Pierre shale.

Skagerrak, uranium content of water......... 79,82 Source rock, influence on uranium content of water in bordering seas.......... 83-85

Sulfides, Chattanoogs shale _ in modern marine muds.............. 76, 91, 92, 94 in modern sea water.................... 76, 93-95 in uraniferous marine black shale...... 76, 90-91

known and theoretical relations, summary ........................... 103-104, 105

laboratory experiments.............. 78, 90,92,93 mechanism of enrichment, bottom water of Norwegian fjords and Baltic

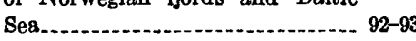
possible extrapolations and interpretations precipitation of uranlum............ 78,90-91 relation of pyrite to urantum.......... 91-92

Summary, conclusion . 104-105 factors controlling uranium distribution in black shales.................... 101-102 investigations, 1944-57.................... 73-74 known and theoreticel relations
Sweden, uranium-bearing black shale and kolm................ 68, 71, 82, 83-84,88

$\mathbf{U}$

Uraniferous black shale, defined.............. 70 investigations.............................. 70-74 source of uranium, summary.............. 105 See also Chattanooga shale and Pennsylvanian black shales.

Uranium, a trace element in black shale...... 70 amount contributed by constituents of shales and muds.................... 105 average content, river water................ 81, 82 sea water.............................. 76, 81, 83 shale _. 70, 10 chemical constituents and properties controlling concentration............. 76-77 in marine black shale ...... $71,76,80,81,83,84-85$ in modern marine muds.......... $76,83,86,87,90$ In modern sea water.............. 76,81-82,83,84 in water, laboratory experiments. $78,84,87,93,98$ independent of phosphate in marine black shale............... 96

known and theoretical relations, organlo matter............................ 103

source 102-103, 105 limitation of amount precipitated by hydrogen sulfide... ... $93-94$ mechanisms of enrichment _..._.... 74, 86-100 mechanisms of transportation............. 81 relation to acidity . . relation to phosphate................... 97, 98, 104 relation to pyrite. sources_........... 74, 80-85 summary of factors controlling distribution in black shale.............. 101-102

summary of known and theoretical relations, hydrogen sulfide...... 103-104, 105

Uranlum-bearing shale and mud, examples... 75-80

Variables as mechanisms of enrichment

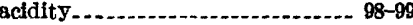
oxidation-reduction potential ............. 99 salinity ............... $99-100$

Volcanic rock, possible source of uranium in ancient ses water................... 84-85

$\mathbf{W}$

Woodford shale, studied for uranium content. 